San Jose State University

SJSU ScholarWorks

Master's Theses

Master's Theses and Graduate Research

Fall 2010

\title{
Ecology of Foothill Yellow-Legged Frogs in Upper Coyote Creek, Santa Clara County, CA
}

Thomas Earl Gonsolin

San Jose State University

Follow this and additional works at: https://scholarworks.sjsu.edu/etd_theses

\section{Recommended Citation}

Gonsolin, Thomas Earl, "Ecology of Foothill Yellow-Legged Frogs in Upper Coyote Creek, Santa Clara County, CA" (2010). Master's Theses. 3861.

DOI: https://doi.org/10.31979/etd.92qs-k82g

https://scholarworks.sjsu.edu/etd_theses/3861

This Thesis is brought to you for free and open access by the Master's Theses and Graduate Research at SJSU ScholarWorks. It has been accepted for inclusion in Master's Theses by an authorized administrator of SJSU ScholarWorks. For more information, please contact scholarworks@sjsu.edu. 
ECOLOGY OF FOOTHILL YELLOW-LEGGED FROGS IN UPPER COYOTE CREEK, SANTA CLARA COUNTY, CA

\author{
A Thesis \\ Presented to \\ The Faculty of the Department Biological Sciences \\ San José State University
}

In Partial Fulfillment

of the Requirements for the Degree

Masters of Science

by

Thomas Earl Gonsolin, Jr.

December 2010 
(C) 2010

Thomas E. Gonsolin, Jr.

ALL RIGHTS RESERVED 
The Designated Thesis Committee Approves the Thesis Titled

ECOLOGY OF FOOTHILL YELLOW-LEGGED FROGS IN UPPER COYOTE CREEK, SANTA CLARA COUNTY, CA

by

Thomas Earl Gonsolin Jr.

APPROVED FOR THE DEPARTMENT OF BIOLOGICAL SCIENCES SAN JOSÉ STATE UNIVERSITY

December 2010

Dr. Jerry J. Smith

Dr. Paula Messina

Dr. Sarah J. Kupferberg
Department of Biological Sciences

Department of Geology

Department of Integrative Biology-UC Berkeley 


\section{ABSTRACT \\ ECOLOGY OF FOOTHILL YELLOW-LEGGED FROGS IN UPPER COYOTE CREEK, SANTA CLARA COUNTY, CA}

by Thomas Earl Gonsolin Jr.

Visual encounter surveys, mark-recapture technique, and telemetry were used investigate breeding, movement, growth, habitat preferences, and predators of foothill yellow-legged frogs on Coyote Creek in Santa Clara County, California, from March 2004 to March 2006. The main stem and tributaries were intermittent in summer in all three years. Thermal conditions for breeding initiation were alike during 2004, 2005, and 2006. Breeding occurred in the main stem on descending limbs of the hydrograph. No breeding occurred in the middle main stem reach, which is ephemeral. Breeding occurred at less than an order of magnitude greater than base flows. Typically, larger females bred earlier, and egg mass size decreased as the breeding season progressed during 2004 and 2005. Males arrived earlier and remained in breeding areas longer. Resident tributary frogs moved greater distances than main stem frogs to breed. Females tended to travel farther than males and occupied habitats farther from the breeding areas. Frogs on Coyote Creek showed faster growth during their first year than Sierra Nevada and north Coast Range populations. Both sexes preferred pools and boulder-dominated habitat on both the main stem and tributary. Santa Cruz garter snakes were the most frequently encountered predator in the study area. However, all diurnal predators were scarce on the tributaries. Perennial water is a limiting factor within the study area, as illustrated by the movement patterns and timing of breeding. 


\section{ACKNOWLEDGMENTS}

I thank my family and friends for their encouragement for my project. I thank Christina Lawson for editing and formatting the final product and Jae Abel, Kristine Atkinson, Jim Gonsolin, and Steve Wilson for their help with field data collection. This project would not have been possible without the permission to access the study area and support of the Santa Clara County Open Space Authority (SCCOSA). Special thanks go to the manager of SCCOSA, Pat Congdon, who was invariably supportive and enthusiastic of my work. I am grateful to my committee advisers, Dr. Jerry J. Smith, Dr. Sarah Kupferberg, and Dr. Paula Messina. Their experience, knowledge, and belief in me were essential to this project. I also thank other researchers of R. boylii: Amy Lind, Sarah Yarnell, Joe Drennan, and Ryan Bourqe for sharing conversations, advice, and ideas.

I dedicate this project to my family and friends, who were supportive of my work throughout the entire process. In addition, I dedicate my efforts to future researchers of $R$. boylii. My hope is this thesis will help them during all phases of their work. Much more focused research needs to be conducted to increase our understanding of a species in decline and to help guide conservation measures that will allow the species to persist and perhaps re-establish populations in watersheds where they have been extirpated. 


\section{TABLE OF CONTENTS}

Page

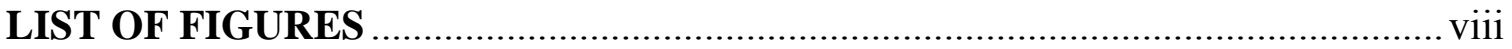

LIST OF TABLES

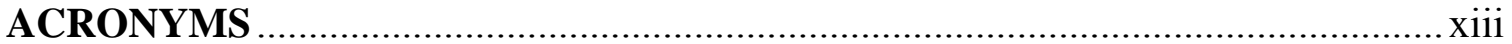

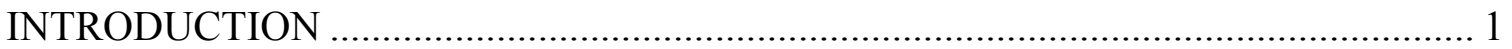

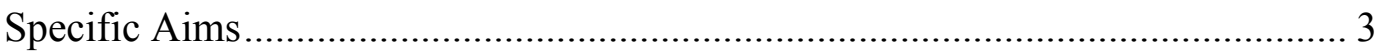

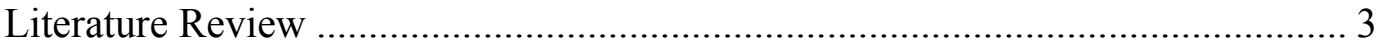

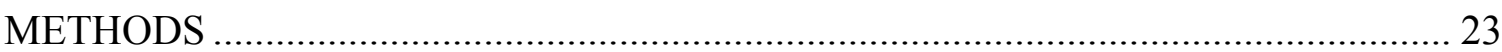

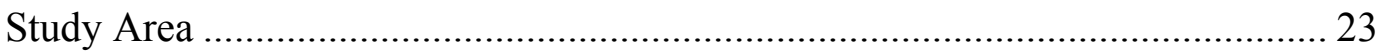

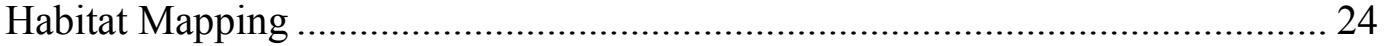

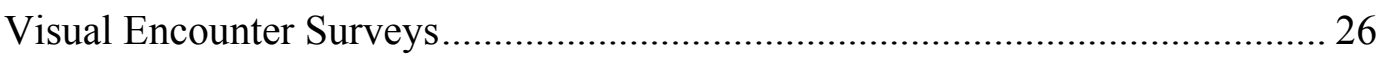

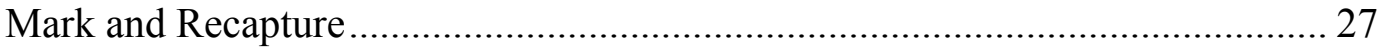

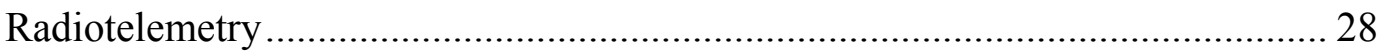

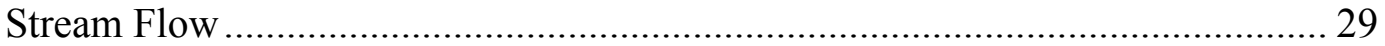

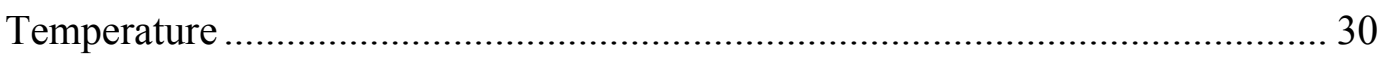

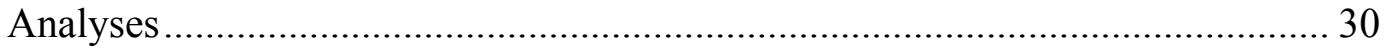

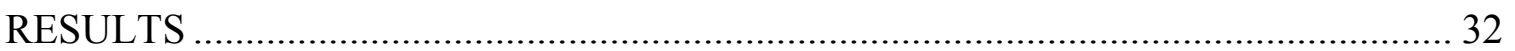

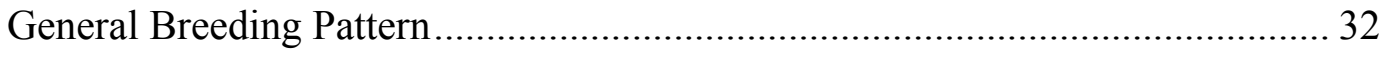

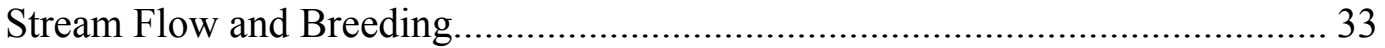

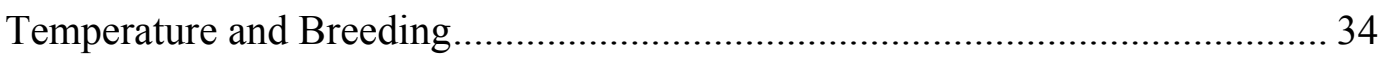

Physical and Habitat Parameters for Egg Masses................................................ 35 


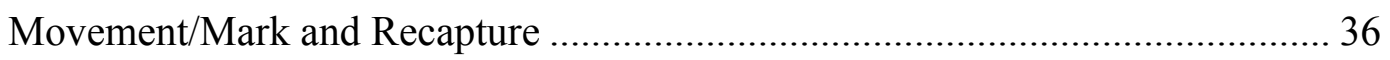

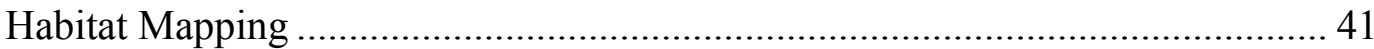

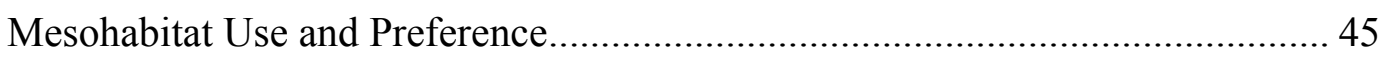

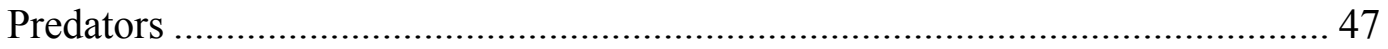

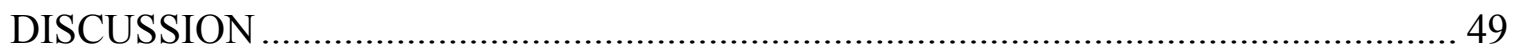

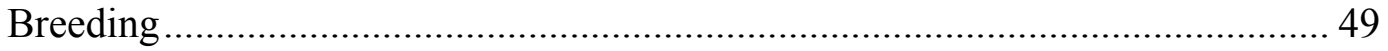

Movement/Mark and Recapture ………........................................................ 55

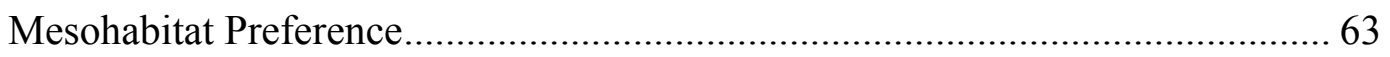

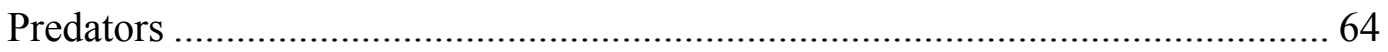

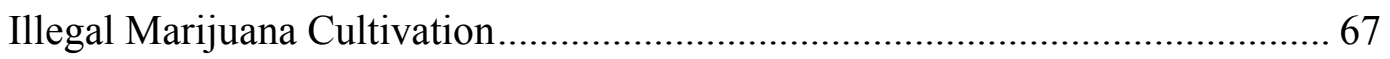

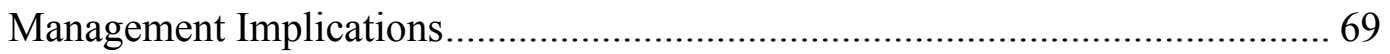

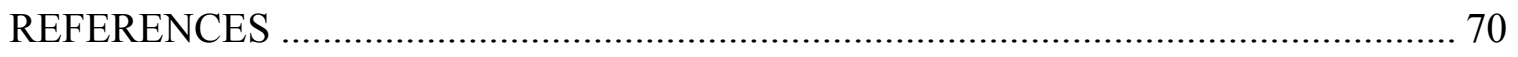

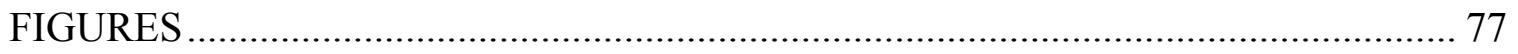

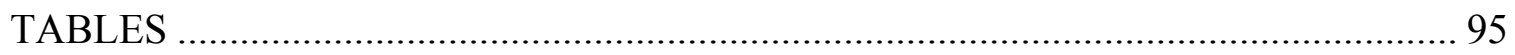

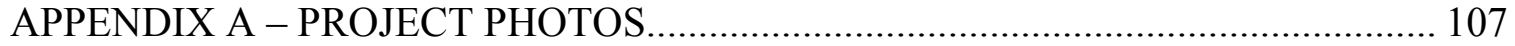




\section{LIST OF FIGURES}

FIGURE 1.-Map of study area. Data collection occurred on upper Coyote Creek between the high water mark of the reservoir and Gilroy Hot Springs.

FIGURE 2.-Egg mass diameter through the breeding season on the lower reach of Coyote Creek in 2005.

FIGURE 3.-Egg mass diameter through the breeding season on the upper reach of Coyote Creek in 2005 .

FIGURE 4.- Stream flow in association with daily oviposition on the lower reach of Coyote Creek in 2004. Numbers indicate the number of new egg masses observed during surveys.

FIGURE 5.- Stream flow in association with daily oviposition on the upper reach of Coyote Creek in 2004. Numbers indicate the number of new egg masses observed during surveys.

FIGURE 6.-Stream flow in association with daily oviposition on the lower reach of Coyote Creek in 2005. Numbers indicate the number of new egg masses observed during surveys.

FIGURE 7.- Stream flow in association with daily oviposition on the upper reach of Coyote Creek in 2005. Numbers indicate the number of new egg masses observed during surveys.

FIGURE 8.-Water temperature in association with daily oviposition on the lower reach of Coyote Creek in 2005.

FIGURE 9.-Water temperature in association with daily oviposition on the upper reach of Coyote Creek in 2005.

FIGURE 10.- Number of frogs observed during lower reach main stem site surveys and recorded daily mean water temperatures during the pre-breeding/breeding season in 2005.

FIGURE 11.- Number of female and male frogs observed during surveys and recorded mean daily water temperatures during the prebreeding/breeding season in 2005 .

FIGURE 12.-Purpose for maximum movement of recaptured frogs during different seasons. 
FIGURE 13.-Maximum distances traveled for individual frogs during the prebreeding/breeding and non-breeding seasons.

FIGURE 14.-Movement histories of individual females that resided in Dexter Creek during the non-breeding season. Negative y axis movements were distances traveled on the main stem from the confluence with Dexter Creek.

FIGURE 15.-Movement histories of individual males that resided in Dexter Creek during the non-breeding season. Negative y axis movements were distances traveled on the main stem from the confluence with Dexter Creek.

FIGURE 16.-Movement histories of individual main stem resident females on Coyote Creek.

FIGURE 17.- Movement histories of individual main stem resident males on Coyote Creek.

FIGURE 18.- Observed activities of radiotagged versus non-radiotagged frogs on Dexter Creek in 2005.

FIGURE 19.- - Location of radiotagged versus non-radiotagged frogs in relation to the active channel on Dexter Creek.

FIGURE 20.--Microhabitat use by observed non-radiotagged foothill yellowlegged frogs on Coyote and Dexter Creeks.

FIGURE 21.-Position in pools for radiotagged versus non-radiotagged foothill yellow-legged frogs on Dexter Creek.

FIGURE 22.-Daily observed and predicted adult female growth rates.

FIGURE 23.- Observed individual female growth rates versus growth curves for small metamorphs.

FIGURE 24.- Growth curves for selected female foothill yellow-legged frogs during 2004-2005.

FIGURE 25.- Growth curves for selected male frogs during 2004-2005. .90

FIGURE 26.- Growth curves for selected male frogs during 2004-2005.

FIGURE 27.-- Rosgen Level II Channel morphology composition by reach for the Coyote Creek study area. 
FIGURE 28.-Mesohabitat composition for the Coyote Creek study area.

FIGURE 29.- Observed diurnal predator composition on the main stem of upper Coyote Creek during 2004-2005.

FIGURE 30.-Female body mass of resident frogs versus distance from the breeding area.

FIGURE 31.-Male body mass of resident frogs versus distance from the breeding area..

FIGURE 32.-Comparison of monthly daily mean air temperatures during summer 2005, between the lower reach of Coyote Creek and Dexter Creek.

FIGURE 33.-Comparison of growth rate predicted by VBGE for Coyote Creek and Feather River setting metamorphosis at $22 \mathrm{~mm}$. 


\section{LIST OF TABLES}

TABLE 1.-Foothill yellow-legged frog 2004 and 2005 breeding season

Page summary on Coyote Creek upstream of Coyote Reservoir in Santa Clara County, CA ..................................................................................96

TABLE 2.-Hatching success (egg mass survival) of egg masses on Coyote Creek 2004-2005.

TABLE 3.-Mesohabitat use percentages for 176 foothill yellow-legged frog egg masses laid within the study area on Coyote Creek in 2004-2005.

TABLE 4.-Microhabitat parameter utilization for egg masses deposited within the study area on Coyote Creek in 2004-2005.

TABLE 5.-Attachment substrate of egg masses on Coyote Creek in 2004-2005

TABLE 6.-Breeding habitat parameter values measured at egg mass locations along Coyote Creek in 2004-2005.

TABLE 7.- Juvenile frogs marked and recaptured from 2004 to 2005

TABLE 8.- Size ranges of adult foothill yellow-legged frogs captured within the study area during 2004-2005.

TABLE 9.- Number of males and females captured and sex ratios at the lower and upper reaches in 2005 and summer residence locations between lower main stem and Dexter Creek in 2004 and 2005.

TABLE 10.-Detectability of non-radiotagged stationary adult foothill yellowlegged frogs on Dexter Creek concurrent with radiotracking.

TABLE 11.-Mesohabitat physical parameter values by reach for the Coyote

Creek study area

TABLE 12.-Dominant and sub-dominant substrate by reach for the Coyote Creek study area.

TABLE 13.-Escape cover availability by reach for adult foothill yellow-legged frogs in the Coyote Creek study area.

TABLE 14.-Adult foothill yellow-legged frog mesohabitat availability and use during summer/fall in the Coyote Creek study area. Total observations includes, frogs not captured and sexed. 
TABLE 15.-Dominant substrate mesohabitat availability and use by adult foothill yellow-legged frogs, in the Coyote Creek study area...................105

TABLE 16.-Depth, canopy and cover complexity of mesohabitats available and used by adult foothill yellow-legged frogs in the Coyote Creek study area. 


\section{ACRONYMS}

$\begin{array}{ll}\text { Bd } & \text { Batrachochytrium dendrobatidis } \\ \text { cfs } & \text { cubic feet per second } \\ \text { cms } & \text { cubic meters per second } \\ \text { FERC } & \text { Federal Energy Regulatory Commission } \\ \text { mps } & \text { meters per second } \\ \text { mtDNA } & \text { mitochondrial DNA } \\ \text { SCCOSA } & \text { Santa Clara County Open Space Authority } \\ \text { SVL } & \text { snout to vent length } \\ \text { VBGE } & \text { Von Bertalanffy Growth Equation } \\ \text { VES } & \text { visual encounter surveys }\end{array}$




\section{INTRODUCTION}

The foothill yellow-legged frog (Rana boylii) is one of four native, ranid species which reside in California (Stebbins 2003). It is unique among these ranids in its exclusive association with running waters to complete its life cycle. The current status and distribution of foothill yellow-legged frogs is not entirely known. Populations have disappeared throughout their historic range, particularly on the west slope of the Sierra Nevada foothills and farther south. Due to the declines and stream habitat requirements of foothill yellow-legged frog, these frogs have become a focal species in Federal Energy Regulatory Commission (FERC) hydropower relicensing projects (Lind et al. 2008).

Potential causes of decline are numerous, including reservoir and road construction, reservoir operations, logging, water quality degradation, and non-native predators. Predation by introduced fish and bullfrogs (Rana catesbeiana) has been blamed for foothill yellow-legged frog declines (Moyle 1973; Jennings and Hayes 1988; Kupferberg 1996a; Ashton et al.1998; Ashton and Nakamoto 2007). Foothill yellow-legged frog declines have been part of a more general decline in amphibians in the western United States. Studies have implicated solar UV-B for amphibian declines in the western United States (Blaustein 1994a). Pesticide drift from the Sacramento and San Joaquin Valleys has been argued as a factor in ranid declines in the Sierra Nevada (Drost and Fellers 1996; Davidson et al. 2002). Large die-offs of amphibians from chytrid fungus have been documented in California (Fellers 2001), and other pathogenic fungi contribute to amphibian losses in the western United States (Blaustein et al. 1994b). 
Although there is no evidence for a singular range-wide cause for foothill yellowlegged frog declines, there are many studies that have associated the presence or absence of this species with physical habitat parameters of their streams and rivers, which include flows, substrate, and canopy coverage (Zweifel 1955; Hayes and Jennings 1988; Van Wagner 1996; Kupferberg 1996b; Yarnell 2000; Ibis Environmental Inc. 2002). Effects of flow fluctuations on breeding habitat and egg survival were studied on the Trinity River (Lind et al. 1996). Geomorphic and hydrologic factors on habitat suitability have been studied in the Sierra Nevada (Kupferberg 1996b; Yarnell 2000).

However, some life history aspects of foothill yellow-legged frogs are not well understood. There are no publications regarding movement and dispersal of foothill yellow-legged frogs during different life history stages (Jennings and Hayes 1994; Ashton 1998). There have been no studies documenting winter habitat use. No studies of any kind have been published on foothill yellow-legged frogs in the Coast Ranges south of San Francisco.

To address the knowledge gaps on movements and habitat use by foothill yellowlegged frogs, I investigated habitat preference of adults in a partially intermittent stream reach in the Diablo Range south of San Francisco Bay, within a poorly studied region within the species' range in the central coast of California. I collected data on breeding locations and timing in association with stream flow and water temperatures at two breeding sites. This study may give insight to factors in declines of foothill yellowlegged frogs at the watershed level, particularly on streams altered by water diversions or with natural low summer flows. I also determined seasonal movement patterns and 
habitat utilization that are distinctive to the central coast, which may also aid government agencies and land managers to enact measures for conservation of this species that are regionally relevant.

\section{Specific Aims}

My objectives for this study were to quantify:

1. Timing of breeding, breeding habitat utilization, and physical environment associated with breeding.

2. Timing, duration, and magnitude of seasonal movements using biotelemetry and tagging studies of foothill yellow-legged frogs in relation to stream flow fluctuation and water temperatures.

3. Seasonal habitat use parameters, including mesohabitat type (i.e., pool, riffle run), mesohabitat maximum depth, cover complexity, substrate composition, and canopy closure.

\section{Literature Review}

Species Description. - The foothill yellow-legged frog is a medium sized frog, with adults ranging in length from 37-82 mm snout to vent (SVL) (Jennings and Hayes 1994). This species is sexually dimorphic at maturity, with females averaging $10-20 \mathrm{~mm}$ longer (SVL) (Zweifel 1955). Adult males have darkened and swollen thumb bases and relatively muscular forearms. Dorsal coloration of this species is variable, but is typically mottled light and dark brown, gray or olive, and sometimes with brick red to match the local substrate. The ventral surface of the hind legs is yellow, usually 
extending to the lower abdomen then fading to white (Jennings and Hayes 1994). The dorsal surface of the hind legs of adults has dark colored bands. Typically, there is dark brown mottling on the ventral surfaces where yellow pigment is absent. Yellow and dark mottled ventral coloration is not present or is faint in juveniles. They are also distinguished from other frogs and toads by horizontal pupils, fully webbed hind feet, weakly developed dorsal lateral folds, an obscure tympanum, and by a strong tendency to jump into flowing water to escape; they lack a black eye mask as in Pacific chorus frogs (Pseudacris regilla) and a dorsal stripe as in California red-legged frogs (Rana draytonii), (Stebbins 2003).

Tadpoles are small and black when they hatch, and are difficult to distinguish from western toads (Bufo boreus) without magnification of mouth parts (Ashton 1998). Their dorsal coloration transforms to olive with irregular brown mottling as they grow. Ventral surfaces appear silvery and almost opaque with the viscera scarcely visible. Tadpoles have a rather flattened body, downward oriented mouthparts, and a dorsal-ventrally reduced tail height compared with other ranids, which may be adaptations to flowing water (Zweifel 1955; Nussbaum 1983).

Distribution and Status.- - Historically, foothill yellow-legged frogs occupied most permanent streams in the Coast Ranges from southern Oregon to the San Gabriel Mountains and the foothills of the southern Cascades and Sierra Nevada to the Tehachapi Range (Jennings and Hayes 1988). It was the most common amphibian encountered in the Rogue River Valley in the early 1900s (Fitch 1938). Isolated populations were reported in San Pedro Matir in Baja California, Elizabeth Lake Canyon in Los Angeles 
County and Sutter Buttes in Butte County, California (Stebbins 2003). The elevation range of this frog extends from sea level to $1,400 \mathrm{~m}(4,500 \mathrm{ft})$ in the Sierra Nevada. Temperatures are likely too cold, and the growing season too short, to provide sufficient resources for embryos to reach metamorphosis before the onset of winter above 1,400 m (Placer County Water Agency 2008). Currently, this frog is found from southern Oregon to the Salinas River watershed and coastal Big Sur and San Luis Obispo watersheds in the Coast Ranges and from the west slope of the Cascades in Oregon to the southern Sierra Nevada (Jennings and Hayes 1994). Large populations appear only in the North Coast ranges from Oregon to Sonoma County, California. Scattered remnant populations remain elsewhere within its historic distribution, but foothill yellow-legged frogs appear to be extirpated in the extreme southern portions of their historic range. Foothill yellowlegged frogs are no longer present in two thirds of their historic range in the Sierra Nevada and 45 percent of their historic range in California (Jennings and Hayes 1988). Jennings and Hayes (1988) reported these frogs were absent from some locations in the Sierra Nevada foothills where Moyle (1973) previously found them to be plentiful. They were absent on all sites checked in the Yosemite area by Drost and Fellers (1996) where they were previously found by Storer (1925). They were considered to be endangered by Jennings and Hayes (1994) in the central and southern parts of their range. Accordingly, they are listed as a federal, USDA Forest Service and California species of concern and are fully protected by the state of California.

Lind (2005) used univariate and multivariate analyses to explore the spatial relationship between the current presence and absence of foothill yellow-legged frogs at 
historic sites compared to geographic characteristics (e.g., elevation and latitude), land use impacts, wind-borne toxins and pollutants, climatic factors, and proximity to dams of various sizes. Climatic factors showed the strongest influence in the multivariate analyses. Mean precipitation was positively correlated with presence. Variability of precipitation and percent of dry years were negatively correlated with presence. In addition, Lind (2005) found that the negative impacts of dams were intensified in areas with low mean annual precipitation.

Reproduction and Life History.-Adult frogs aggregate in the cobble dominated areas of streams during spring (Storer 1925; Zweifel 1955). Typically, breeding occurs from late March through May, and initiation of oviposition occurs as water temperatures increase to $12-15^{\circ} \mathrm{C}$, and as stream flows are decreasing near the end of the wet season (Zweifel 1955; Kupferberg 1996b; Fuller and Lind 1991; Seltenrich and Pool 2002). However, temperatures recorded on the Poe Reach of the Feather River during 2004 were close to $10^{\circ} \mathrm{C}$ during initiation of breeding (GANDA 2008). Warmer and drier than usual conditions in 2007 were the likely cause of observed early water temperature increases and initiation of breeding by foothill yellow-legged frogs two to three weeks earlier than typical across northern California (Placer County Water Agency 2008). Kupferberg et al. (2009) concluded that breeding initiation is cued by increasing water and air temperature rather than stream flow. After seventeen years of monitoring on the South Fork of the Eel River, only a weak trend toward breeding later in the year during wet years was observed (Kupferberg 1996a). In addition, availability of shallow, low velocity margin 
areas did not cue breeding. Oviposition may be postponed by rain once adults arrive in breeding areas.

Length of breeding season is variable among populations (Storer 1925; Zweifel 1955). Breeding season length on Hurdygurdy Creek in Del Norte County, California varied between three to seven and a half weeks from 2002 to 2007 (Wheeler and Welsh 2008). Foothill yellow-legged frogs at Hurdygurdy Creek displayed prolonged rather than explosive breeding. Wheeler and Welsh (2008) found that date within the breeding season and stream flow, rather than temperature, influenced breeding activity. They concluded initiation and length of the breeding season was strongly influenced by the natural hydrologic cycle.

Mating calls from males generally occur underwater, but may be made above water (MacTeague and Northern 1993). Calls above water may be heard up to $50 \mathrm{~m}$ away (Ashton and Lind 1998). Females tend to select larger males for amplexus, as males in amplexus were larger than males never seen in amplexus (Wheeler and Welsh 2008). Males grasped onto females and were carried to the exact oviposition location of the females choosing. These locations were often different from the calling locations of the males.

Egg masses are usually found near sunny stream margins in shallow pools, protected edgewater areas, and pool tailouts, and are most often associated with cobble (75-300 $\mathrm{mm})$ or boulder $(>300 \mathrm{~mm})$ bars at flow velocities of $0.0-0.21 \mathrm{~m} / \mathrm{sec}$ and in water depths less than $0.50 \mathrm{~m}$ (Zweifel 1955; Hayes and Jennings 1988; Van Wagner 1996; Kupferberg 1996b). These sites are often at tributary confluences, backwater pools, or 
pool tailouts with coarse substrates (Placer County Water Agency 2008). However, egg masses may be deposited in atypical habitat such as deep slack waters near pool heads or deep backwater pools, when preferred breeding habitat is not available (Seltenrich and Pool 2006). Selected areas provide the best available protection from high or fluctuating stream flows. Egg masses have been documented to only withstand flow velocities at or less than $0.21 \mathrm{~m} / \mathrm{sec}$. Egg masses have been reported to be lost during high flow events (Lind et al. 1996). These high flow events may be the result of dam spills, dam releases, or intense late spring storms. Egg masses are often attached to the lee side of cobbles, large gravel and boulders, but woody debris, and submerged vegetation may also be used (Fuller and Lind 1991). Shallow waters with low velocities and large substrates represent the highest quality for breeding sites and larval rearing (Lind et al. 2009).

Egg masses at oviposition are clear to blue, compact and gelatinous (Storer 1925). They soon absorb water, expand, lose blue coloration, and resemble a cluster of tiny grapes. Egg masses are generally plum size (Storer 1925) to fist size (Stebbins 2003), but show a wide size range. An individual egg with its three gelatinous envelopes is about $5.4 \mathrm{~mm}$ in diameter (Storer 1925). Egg masses typically contain about 200 to 300 eggs, but may vary between 100 to over 1,000 .

Eggs may hatch from 5 to over 30 days after oviposition (Zweifel 1955). Researchers have found hatching to occur within 14 days in the north Coast Ranges in California (Zweifel 1955; Kupferberg 1996a) and Southern Oregon (Nussbaum et al. 1983), and 31 days in the Sierra Nevada (Van Wagner 1996). Slower development occurs with cooler temperatures (Ashton and Lind 1998). In the absence of disturbance, newly hatched 
tadpoles remain near egg masses for several days. Generally, metamorphosis takes place within three to four months, and tadpoles do not overwinter. Larval development and growth in many amphibians have been correlated with water temperatures and food availability (Duellman and Trueb 1986). Maturation is achieved once foothill yellowlegged frogs reach $40 \mathrm{~mm} \mathrm{SVL} \mathrm{(Zweifel} \mathrm{1955).} \mathrm{Reproductive} \mathrm{organs} \mathrm{are} \mathrm{active} \mathrm{by} \mathrm{their}$ second summer, and frogs were found to reproduce as early as six months after metamorphosis in the Central Valley (Jennings and Hayes 1988). However, breeding usually occurs when they are a full two years old (Zweifel 1955; Van Wagner 1996).

The life span of foothill yellow-legged frogs is unknown, and little is known of amphibian life spans in the wild (Duellman and Trueb, 1986). Females tend to live longer than males, and are often found to be three years or older (Zweifel 1955; Van Wagner 1996). In contrast, males were rarely found to be older than two years. However, males at least three or four years old were recaptured during a study on the North Fork Feather River and were the same size as three year old males at recapture (Drennan, pers. comm. 2008). Other species of ranids in the wild may live twelve or more years (Duellman and Trueb 1996).

Food Habits.-Foothill yellow-legged frog tadpoles feed on algae and diatoms scraped from rocks and plants (Vollmar 2002). Tadpoles appear to have faster growth rates feeding on epiphytic diatoms and preferentially feed on them (Jennings and Hayes 1994). Tadpoles may gather around other dead tadpoles, possibly to feed on dead tissue or algae and diatoms (Ashton 1998). Feeding ceases during metamorphosis, as the digestive system transforms to handle animal tissue and the tail is re-absorbed (Duellman 
and Trueb 1986). Once metamorphosis is complete, foothill yellow-legged frogs feed mainly on terrestrial invertebrates (Zeiner et al. 1988). Food includes ants, flies, hornets, grasshoppers, beetles, moths, snails, and water striders (Nussbaum 1983). Van Wagner (1996) reported 90 percent of food eaten by these frogs was terrestrial arthropods, consisting of 87.5 percent insects and 12.6 percent arachnids. Ninety-eight percent of frogs sampled on Cache Creek, a Clear Lake tributary, had terrestrial arthropods in their stomachs (Hothem et al. 2009). Foothill yellow-legged frogs also eat aquatic invertebrates (Zeiner et al. 1988). Twenty- eight percent of frogs sampled on Cache Creek had eaten aquatic arthropods (Hothem et al. 2009).

Habitat.-Foothill yellow-legged frogs are found in small, ephemeral streams to large rivers and within many types of plant communities, including valley-foothill hardwood, coastal scrub, chaparral, valley-foothill riparian, hardwood-conifer, ponderosa pine, and wet meadow (Stebbins 2003). Typically, they are found on cool, clear, shallow, slow-flowing, rocky streams dominated by cobble $(75-300 \mathrm{~mm})$ substrate (Fitch 1938; Zweifel 1955). They have been reported to use streams with scarce cobble substrate (Fitch 1938; Zweifel 1955), but this appears to be unusual (Jennings and Hayes 1994). Foothill yellow-legged frogs have been found in very atypical habitats, which include man-made tunnels, roadside culverts, and along the banks of reservoirs (Peek and Khandwala 2006).

Foothill yellow-legged frogs prefer sunny banks with partial shading for basking (Jennings and Hayes 1994). Adults are typically seen on sunny banks in cascade, pool or riffle habitats near the water's edge. These frogs have been found using perennial pools 
of otherwise ephemeral tributary streams (Moyle 1973). However, they may be more susceptible to predation in these streams. Soon after embryos hatch, rearing habitat is similar to breeding habitat, but tadpoles may move into shallow, warm, low velocity areas with fine-grained substrates (i.e., gravel/sand) later in the year (Jennings and Hayes 1994).

Foothill yellow-legged frogs were found more often in streams with between 20 and 40 percent canopy cover, consisting of more than 40 percent riffle habitat, and having at least 40 percent cobble substrate (Yarnell 2000). Kupferberg (1996b) found that large boulders that did not move at stream discharges below bankfull can slow and stabilize stream velocities. Boulders are important for safe basking locations and predator avoidance (Jennings 1988). In addition, foothill yellow-legged frogs typically occur on stream reaches with high width/depth ratios (low channel confinement), high meander/width ratios (high sinuosity), low to moderate gradients ( $<6.5$ percent), and cross-sectional configurations that include side channels (Kupferberg 1996b; Ibis Environmental Inc. 2002).

Yarnell (2000) found that seasonal habitat preferences of different age classes were related to channel shape and streambed surface texture. Juveniles utilized relatively swift, narrow channels during fall low flows and then switched to wide, shallow channels with protected backwater areas during winter/spring high flows. Adults were usually found in confined channels with deep, narrow pools year-round. Adults occupied primarily the deeper pools with open canopies. In addition, Kupferberg (1996b) found that the presence of foothill yellow-legged frogs was positively correlated with stream 
reaches within $400 \mathrm{~m}$ ( 0.25 mile) of tributary confluences. Adults used the tributaries for overwintering and used the main stem for breeding.

Movement and Dispersal.—Diel and seasonal movements of foothill yellow-legged frogs and behavior of adults are poorly known (Jennings and Hayes 1994; Ibis Environmental, Inc. 2002). They do not leave riparian areas during storms, do not utilize open areas at night, and are not seen on roads as are other ranids such as Rana pipiens or Rana aurora (Zweifel 1955). During the non-breeding season, home ranges appeared to be quite small in adult foothill yellow-legged frogs, with average distance moved of $8 \mathrm{~m}$ (Van Wagner 1996). Morey (2000) suggested home ranges were probably less than 10 m. Breeding movement initiation temperatures are as low as $10^{\circ} \mathrm{C}$ (Drennan et al. 2006). Van Wagner (1996) reported average distance moved by adults during the breeding season was $54 \mathrm{~m}$, but maximum distance traveled was $413 \mathrm{~m}$ by females and $408 \mathrm{~m}$ by males. These results suggest adults use a particular habitat for most of the year and move only in search of breeding areas. After the breeding season, adults may be scarce in ephemeral reaches of these breeding streams, even in perennial pools, but they are plentiful in tributaries (Van Wagner 1996). Alternatively, adults may move into vegetation or limit diurnal activity (Ashton 1998).

Young of the year and yearling frogs seem to move both upstream and downstream to areas with surface flow as streams dry back in summer and fall (Van Wagner 1996). There was no significant difference in magnitude of movements of juveniles of both sexes between the breeding season and the remainder of the year (Van Wagner 1996). Juvenile movement was similar to adults during the breeding season, but was much 
greater during the remainder of the year. Van Wagner (1996) reported maximum distances moved during the non-breeding season were $555 \mathrm{~m}$ for a juvenile and $25 \mathrm{~m}$ for an adult female. Van Wagner (1996) suggested juveniles move throughout the year in search of potential breeding habitat. There are no studies of tadpole dispersal distances.

Recent studies have revealed additional details of seasonal movements of adult foothill yellow-legged frogs. Wheeler and Welsh (2008) found that male frogs congregated at breeding areas during the breeding season, but females arrived asynchronously. On Red Bank Creek, a perennial tributary to the Trinity River in Tehama County, California, 60 adult frogs were followed using biotelemetry (Bourque 2008). Bourque found frogs seldom moved far from the wetted channel, and movement rates differed between the sexes with females traveling at higher rates during spring. Long distance seasonal movements to and from breeding areas were confined to the spring breeding season. Another study tracked movements of 476 adult frogs on a regulated section of the North Fork Feather River (Drennan et al. 2006). They found adult frogs showed high site fidelity within tributaries to the main stem of the river, which were home to adult frogs outside of the breeding season. Movements toward the main stem breeding areas were triggered by day length. Males initiated movements first and left the breeding areas later than females. Females traveled at a much faster rate (up to $316.5 \mathrm{~m} /$ day) than males (up to $58.1 \mathrm{~m} /$ day). Adults started breeding in the main stem once water temperatures increased to $10^{\circ} \mathrm{C}$ and flows were $\leq 55$ percent of summer base flow on a descending limb of the hydrograph. Female's length of stay was affected by flows and sex ratio. High flows or a scarcity of males delayed breeding and increased the 
amount of time females spent at the breeding sites. Males typically used breeding sites next to their home tributaries. However, some males utilized breeding locations near other tributaries.

Genetics.-Genetics studies for foothill yellow-legged frogs are limited. Lind (2005) analyzed two fragments (Cytochrome B and ND2) of mitochondrial DNA (mtDNA). These analyses showed several supported geographical clades within foothill yellowlegged frog that matched well with differences between clades in other taxa. The geographic breaks between clades fit with hydrologic regions that are likely to be poor dispersal corridors for foothill yellow-legged frogs. Genetic differentiation was generally low among populations within the largest clade. However, frogs in several localities showed significant divergence.

Another study analyzed both mtDNA and random amplified polymorphic DNA (RAPD) markers (Dever 2007). Dever sampled seven tributaries along the relatively pristine reach of the Eel River in northern California. The RAPD markers showed a positive correlation between genetic and geographic distance, and tributaries more than $10 \mathrm{~km}$ from each other exhibited little gene flow. The southern and northern tributaries were separated by cluster analysis. However, little geographic structure was found when the mtDNA was analyzed. Recent divergence, sex biased dispersal or the low number of loci used may explain the different results. The relatively pristine study area, with a lack of pollution, dams, roads, and other manipulations, had a large population with a high level of genetic diversity. A follow-up study within this reach of the Eel River sampled nine tributaries, utilized three RAPD markers, and sampled many more individual frogs 
(Poch and Dever 2008). They found high similarity among individuals of different tributaries, as evidence for significant genetic flow among the tributaries of the Eel River.

Predation.-Foothill yellow-legged frogs are consumed by a wide variety of predators, including birds, mammals, insects, reptiles, and other amphibians (Duellman and Trueb 1986). The primary native predators throughout the range of foothill yellowlegged frogs are garter snakes (Thamnophis spp.). Western aquatic garter snakes (Thamnophis couchi and Thamnophis atratus) are known to take a heavy toll on all life stages (Nussbaum 1983; Jennings and Hayes 1988; Lind and Welsh 1994). Other species of garter snakes (Thamnophis spp.) prey primarily on postmetamorphic stages (Nussbaum 1983; Ashton et al. 1998). Rough skinned newts (Taricha granulosa) have been reported to feed on egg masses of foothill yellow-legged frogs in Southwestern Oregon (Evendon 1948). Foothill yellow-legged frog tadpoles are a component of the diet of Sacramento pikeminnow (Ptychocheilus grandis) (Brown 1982). Egrets, herons, and passerine birds have been known to consume tadpoles and post-metamorphic frogs of various anuran species (Duellman and Trueb 1986). Raccoons (Procyon lotor) may opportunistically prey on foothill yellow-legged frogs (Zweifel 1955).

A principal non-native predator of foothill yellow-legged frogs is bullfrogs. Bullfrogs compete for the same resources as well as prey on native ranids throughout the West Coast (Hayes and Jennings 1986; Jennings and Hayes 1988; Kupferberg 1996b). Bullfrog predation on foothill yellow-legged frogs was observed during a study on Cache Creek, a Clear Lake tributary, but the amount of predation was not determined (Hothem et al. 2009). Non-native Centrarchids (basses and sunfishes) prey heavily on both egg 
masses and tadpoles (Hayes and Jennings 1986). Tadpoles are particularly vulnerable to small, fast, maneuverable sunfish such as green sunfish (Lepomis cyanellus), because tadpoles have limited speed and stamina (Hayes and Jennings 1986). Signal crayfish (Pacifasticus leniusculus) were captured on video feeding on egg masses on the North Fork Feather River and may contribute to egg mass detachment (Jackman et al. 2004). In addition, observations of tadpoles during visual encounter surveys (VES) suggest that signal crayfish feed on tadpoles, based on tail injuries (Drennan et. al 2005). Introduced signal crayfish are present in many watersheds with foothill yellow-legged frogs. They may pose a serious threat, because foothill yellow-legged frogs lack evolutionary experience coping with crayfish predation (Drennan et. al 2005).

Competition.-A study by Kupferberg (1996a) found that competition between foothill yellow-legged frogs, Pacific chorus frogs (Pseudocris regilla), and bullfrog tadpoles resulted in a 48 percent reduction in survivorship of foothill yellow-legged frog tadpoles, and a 16 percent reduction in size at metamorphosis. Tadpoles competed for algae directly in this experiment. Bullfrog tadpoles devoured most of the algae, due to their greater size. Bullfrog tadpoles usually require more than one year to metamorphose and consume algal resources year-round (Kupferberg 1996b). The foothill yellow-legged frog co-exists with red-legged frogs on some streams, but competition is minimized by resource and habitat partitioning (Hayes and Jennings 1988).

Altered Stream Flow Regimes.-Flow alterations from impoundments are a great threat to foothill yellow-legged frog populations throughout their range (Hayes and Jennings 1988). Impoundments may also result in habitat fragmentation and reduced 
connectivity of meta-populations. Reduced summer stream flows may concentrate frogs into perennial pools, increasing susceptibility to predation (Hayes and Jennings 1988). Habitat changes induced by altered flow regimes may create habitat preferred by bullfrogs, which are predators and competitors of foothill yellow-legged frogs (Hayes and Jennings 1988). Bullfrogs thrive in reservoirs and dredge ponds where water may be warm and of poor quality.

Wheeler and Welsh (2008) suggested that anthropogenic manipulation of stream flows during the breeding season may suppress reproductive behavior and output of egg masses. The magnitude and timing of spring pulsed flows from reservoirs greatly influence whether embryos survive long enough to hatch (Kupferberg et al. 2009). Smaller pulsed flows later in the breeding season may cause higher egg mortality than early season high magnitude pulsed flows, because jelly cohesion among eggs, and adhesion to substrates are diminished in older egg masses. Effects of egg mass scour from pulsed flows may not be detectable for two or three years. A three-year lag time between recruitment conditions and adult population size was observed in comparisons made between two reaches on the North Fork Feather River (Kupferberg et al. 2009). Farther south, populations may have a two year lag time (S. Kupferberg Personal Communication).

Impoundments may cause an artificial increase or decrease in water temperatures downstream (Catenazzi and Kupferberg 2009). Lower than natural summer releases most often result in unnaturally high stream temperatures. By contrast, cooler than normal water temperatures may result from releases from a reservoir's hypolimnion (the 
cold bottom layer of a lake). Cooler releases can result in nearly doubling the amount of time eggs take to hatch or tadpoles take to complete metamorphosis and often result in smaller tadpole sizes at metamorphosis than tadpoles reared at warmer temperatures (Catenazzi and Kupferberg 2009). However, warmer temperatures were associated with outbreaks of the copepod Lernaea cyprinacea in foothill yellow-legged frogs in experimental enclosures. Survival to metamorphosis was highest at intermediate temperatures.

An extensive survey effort by Garcia and Associates (2002) on the North Fork Feather River failed to find foothill yellow-legged frogs in habitats which appeared suitable for this species. The study areas were below impoundments operated by Pacific Gas \& Electric for hydroelectric power generation. A study on the Trinity River below Lewiston Dam, reported a 94 percent loss of potential breeding habitat after construction of the dam (Lind et al. 1996). After Trinity River flood flows were reduced, there was encroachment by riparian vegetation and reduced cobble/gravel bar formation. Flow releases had been reduced to 10-30 percent of pre-dam operation flows in both total volume and in periodic high flows (i.e., storm runoff) (Lind et al. 1996). Egg masses have been scoured in several years by high late spring releases from Lewiston Dam (Lind et al. 1996). Ellis and Cook (2004) reported half of known egg masses were scoured by five days of high flow releases on the Pit River in California. They suggested duration of high flows and change in current direction (shearing) had a higher impact than overall magnitude. Jackman et al. (2004) also found pulsed flows scoured half of the egg masses 
on the North Fork Feather River, in only one day. Egg masses may be left to desiccate if receding high flows are poorly timed (Lind et al. 1996; Ashton 1998).

Laboratory and field experiments showed that higher velocities caused short term behavioral responses in tadpoles (Kupferberg et al. 2009). Tadpoles sought refuge within interstitial spaces of substrate. Velocities in which tadpoles could not swim or maintain position within substrate interstitial spaces varied with tadpole size, developmental stage, and population origin. Long term consequences of tadpoles seeking high velocity refuge in substrates were at increased risk of predation and reduced growth rates in larger tadpoles. Tadpole abundance dropped from the hundreds to a few at one site from a period of low flow to high flow and back to low flow during daily fluctuations for recreational whitewater rafting.

Recent hydraulic modeling studies have documented the effects of altered flows for foothill yellow-legged frogs. Lind and Yarnell (2008) used depth, velocity, and substrate as variables to develop a habitat suitability model/criteria for egg and tadpole stages, which are the most susceptible to pulsed flows from hydropower generation or whitewater rafting recreation releases. They found that shallow, slow velocity waters with coarser-grained substrates had the highest suitability for egg and tadpoles. A study employing a two-dimensional hydrodynamic model using an un-regulated and regulated stream accurately predicted suitable breeding locations throughout these study reaches (Lind et al. 2009). Many pulsed flow scenarios were assessed to determine how habitat availability and suitability were affected. Lower discharges during spring provided the greatest weighted usable area for breeding. However, higher initial discharges resulted in 
breeding within sites more resistant to later increases in velocity. Only 20 to 30 percent of suitable tadpole habitat on the un-regulated stream and $<5$ percent for the regulated stream was available during a summer pulsed flow, regardless of the initial flow. The observed differences in available habitat during the pulsed flows on the un-regulated and regulated stream were likely because of differences in channel morphology.

Agrochemicals.-Agrochemicals have been implicated in the decline of amphibians worldwide. Hayes et al. (2002) found hermaphroditism and other deformities in leopard frogs (Rana pipiens) exposed to commonly occurring levels of the widely used herbicide atrazine, both in the laboratory, and in the field. Colborn and Clement (1992) attributed foothill yellow-legged frog population declines to endocrine mimicking chemicals that entered the ecosystem through pesticides and fungicides. Pesticide drift from the Central Valley to the Sierra Nevada, and high pesticide levels in the bodies of Sierra Nevada amphibians, have been well documented in California by Davidson et al. (2002). They found a strong positive association between declines of both California red-legged frogs and foothill yellow-legged frogs in areas downwind of agricultural land use. Fellers et al. (2007) exposed tadpoles for long periods of time in a laboratory to environmentally realistic concentrations of pesticides still in use. They concluded these pesticides are at sufficient concentration levels in the Sierra Nevada to cause a significant decrease in survival rates. Compounds from the breakdown of chlorpyrifos, malathion, and diazinon were found to be 10 to 100 times more toxic than the parent compounds (Sparling and Fellers 2007). Foothill yellow-legged frogs are far more susceptible to pesticides than 
Pacific chorus frogs (Fellers and Kleeman 2009). Chlorpyrifos was three times more toxic and Endosulfan was 40 times more toxic to foothill yellow-legged frogs.

Pathogenic Fungi.-Pathogenic fungi have been documented to contribute to egg mass loss of several amphibians in the Pacific Northwest (Blaustein et al. 1994b). Amphibian declines in the United States and Panama have been linked to the introduced fungus Batrachochytrium dendrobatidis (Bd), which causes chitridiomycosis (Fellers 2001). This disease causes abnormalities in jaw sheaths and teeth rows of tadpoles, and is invariably fatal in populations of some species. An 11 year study on Sierra Nevada yellow-legged frog (Rana sierrae) and southern mountain yellow-legged frog (Rana Muscosa) revealed the extirpation of over 100 populations since 1997, and after the introduction of Bd (Vredenburg et al. 2009). The disease spread at approximately $1 \mathrm{~km} \mathrm{a}$ year in an easterly direction. Infections of frog populations reached 100 percent within weeks. All populations were stable prior to the onset of Bd invasion. Fellers (2001) sampled 25 counties in California and found chitridiomycosis in six species of amphibians including foothill yellow-legged frogs in 10 counties at 73 sites. Consequently, it appears chitridiomycosis affects a variety of taxa and is geographically widespread. Johnson and Saulino (2007) found Bd in all anuran species, including foothill yellow-legged frogs, in and around Pinnacles National Monument, and at a few sites in the western foothills of the San Joaquin Valley. Lowe (2007) found 10 of 12 sites in the Diablo Range within San Benito and Fresno counties were infected with Bd. However, most of post-metamorphic frogs were not infected. All foothill yellow-legged frogs $>40 \mathrm{~mm}$ were chytrid free. 
UV-B Radiation.-A negative correlation was shown between hatching success and UV-B exposure in ranid species of the Pacific Northwest (Blaustein et al. 1994a).

However, Davidson et al. (2002) found that patterns of amphibian declines in the Central Valley and Sierra Nevada in California were not consistent with the UV-B hypotheses. 


\section{METHODS}

\section{Study Area}

Coyote Creek drains a portion of the central Diablo Mountain range in southeast Santa Clara County, and flows into San Francisco Bay at Alviso Slough. Anderson and Coyote reservoirs impound runoff in the downstream end of the foothills portion of Coyote Creek. These reservoirs are operated for aquifer recharge in Santa Clara Valley by the Santa Clara Valley Water District. There are no significant impoundments upstream of Coyote Reservoir. Upstream of the reservoirs, the stream alternates between moderately confined channels, and narrow alluvial valleys. Boulder, cobble, and bedrock are the dominant substrates in the moderately confined sections, and cobble, gravel, and boulder prevail in the channel within the alluvial valleys. Steeper tributaries enter in the alluvial valley reaches.

The study was conducted on upper Coyote Creek, upstream of Coyote Reservoir from the inundation zone to Gilroy Hot Springs (Figure 1). The drainage area upstream of the study area encompasses over 176 square $\mathrm{km}$ (109 square miles). The study reach on the main stem of Coyote Creek was approximately $7.8 \mathrm{~km}$ (4.8 miles) long. Also included were Dexter Creek $3.0 \mathrm{~km}$ (1.9 miles) from confluence and an unnamed tributary below Sheep Ridge $3.5 \mathrm{~km}$ (2.2 miles) from confluence, which are tributaries containing foothill yellow-legged frogs. A small population of California red-legged frogs is sympatric with foothill yellow-legged frogs throughout the watershed upstream of Coyote Reservoir. 
The primary land use of the area adjacent to Coyote Creek upstream of Coyote Lake has been livestock grazing. The Santa Clara County Open Space Authority now owns and manages almost the entire study area. The upper $305 \mathrm{~m}(1,000 \mathrm{ft})$ of the study area is managed by California Department of Parks and Recreation as part of Henry Coe State Park, which contains the rest of the upper watershed. Livestock grazing is allowed on Open Space land, but is managed to minimize effects on natural resources. No grazing is allowed in Henry Coe State Park, but occurs frequently near the park boundaries.

The upland plant communities adjacent to Coyote Creek and its tributaries are oak woodland, (where moister, steep slopes adjoin the stream), and grassland savanna (on drier, flatter habitat). The oak woodland community is dominated by coastal live oaks (Quercus agrifolia) and California bay (Umbellularia californica). Other tree species include blue oak (Quercus douglasii), California buckeye (Aesculus californica), and foothill pine (Pinus sabiniana). Dominant riparian tree species along confined channels are white alder (Alnus rhombifolia), western sycamore (Platanus racemosa), willow (Salix spp.), and big leaf maple (Acer marcophyllum). The dominant trees in the grassland savanna community are coastal live oak and California buckeye with a few valley oaks (Quercus lobata). The dominant riparian species in the alluvial reaches are western sycamore, scattered willows (Salix spp.), and mule fat (Baccharis salicifolia).

\section{Habitat Mapping}

I conducted mesohabitat mapping during spring 2004 as high flows subsided and breeding had ceased. Mesohabitats were identified as pool, riffle, or run (Hawkins et al. 
1993). I used flagging to identify all mesohabitats. I labeled flagging with habitat unit numbers, and I identified bottom or top of habitat units with distances in meters from the downstream ends of the study reaches. I added additional flagging within large habitat units with distances in meters from the bottom of the respective unit, to facilitate pinpointing future frog capture/recapture locations. Physical mesohabitat parameters included: mean depth; maximum depth; and mean width, which were measured with a stadia rod. I measured mesohabitat lengths with a surveyor's hip chain. I determined Rosgen channel geomorphology types by measuring width to depth ratios of the bankfull channel (i.e., channel confinement), the ratio of bankfull channel width to flood prone width (width at twice bankfull depth [i.e., entrenchment]); and channel gradient (Rosgen, 1996).

I collected data on additional habitat parameters for the purpose of determining if these were good predictors of abundances of adult foothill yellow-legged frogs. I identified and recorded instream escape cover types for each habitat. Cover types included: woody debris; undercut bank; boulder/cobble; bedrock; terrestrial vegetation; depths; and water surface turbulence. I measured the percentage riparian canopy closure using a spherical densitometer. I visually estimated abundance of substrate types for each mesohabitat to the nearest 10 percent. Substrate types included: silt/clay; sand; gravel (5-75 mm); cobble (75-300 mm); boulder (>300 mm); and bedrock. In addition, I recorded other aquatic species observed in each mesohabitat. I minimized potential impacts to foothill yellow-legged frog egg masses by identifying breeding locations prior to mapping. In addition, I removed hip chain string as I proceeded. 


\section{Visual Encounter Surveys}

From 14 March 2004 to 16 November 2005 and 14 March to 10 April 2006, I conducted VES at least weekly for the entire study area, where suitable habitat (i.e., water) existed for the duration of the study using the USDA-FS protocols in Standard Operating Procedures for River and Creek Visual Encounter Surveys (Bury and Corn 1991). In addition, I conducted some night surveys on a monthly basis through all suitable habitats. I conducted a total of 215 VES, and all sites were checked at least 60 times. I used binoculars to scout open and exposed areas for frogs (Seltenrich and Pool 2002). I proceeded slowly upstream, zigzagging from one bank to the other searching the banks and channel for egg masses, tadpoles, metamorphs, and adult foothill yellowlegged frogs. I used a dip net to flush frogs from bank vegetation and sweep undercut banks and emergent vegetation. I bypassed dry areas and proceeded to the next suitable habitat. I exercised caution to avoid stirring up sediment or dislodging egg masses of all stream breeding amphibians.

I attempted to capture all frogs with a dip net or by hand. Age class (adult, sub-adult, and metamorph), sex (Stebbins 2003), and SVL were determined and recorded before releasing frogs at the location of capture. I recorded captured and observed frogs to the specific mesohabitat (habitat unit number) and measured distance from exact positions within it from the top or bottom of the habitat. I characterized and recorded microhabitats utilized by frogs as isolated pool, connected side pool, scour pool, backwater pool, side-channels, boulder-sedge, edgewater, pool tailout, riffle, exposed bank, protected bank, or cobble/gravel bar (Seltenrich and Pool 2002; PacifiCorp 2002). 
In addition, I recorded activities of captured and observed frogs as sitting in shade, basking, hiding under substrate, calling, swimming, foraging, amplexus, floating, or underwater (on bottom). I hung flags as close to the capture or location of observation as possible to monitor any changes in distribution of recaptured frogs within or among mesohabitats (Ibis Environmental Services 2002).

I surveyed for egg masses from early March to the end of the breeding season in both 2004 and 2005. In 2006, I surveyed only during March in order to determine when egg laying was initiated on the lower site. I determined specific mesohabitats used (habitat unit number) and exact locations (distance from top or bottom of the habitat) of egg masses or clusters of egg masses. I determined egg mass diameter ( $\mathrm{mm})$, attached substrate diameter $(\mathrm{mm})$, distance from shore, depth at egg mass attachment point, and condition of egg mass (intact, damaged, hatching, hatched). However, egg mass diameters collected during 2004 had a high variability because I could not survey at regular intervals of every two days as in 2005. I estimated numbers of tadpoles for each mesohabitat during each VES. I determined and recorded the same in-channel microhabitat characteristics for tadpoles as for the adults and sub-adults.

\section{Mark and Recapture}

I conducted mark and recapture of frogs simultaneously with VES. I marked 121 adult (>40 mm SVL) and 61 juvenile frogs (young of the year and yearling) for mark and recapture to determine movement patterns from 18 July 2004, to 16 November 2005 . Seventy-two frogs were marked in 2004. These consisted of 32 adults (18 females and 14 males) and 40 juveniles (mostly young of the year). One hundred and ten frogs were 
marked in 2005. These consisted of 89 adults and 21 juveniles. I targeted the larger young of the year that were near $40 \mathrm{~mm}$ during October and November 2004. Males had developed their thumb pads by then. This was also true of frogs $>40 \mathrm{~mm}$ in spring 2005 . I marked frogs with soft, three digit numeric, color coded vi-alpha tags (Northwest Technologies, Inc.) which were injected subcutaneously in the dorsal thigh (Chelgren 2003). I massaged the tags to the ventral side of the thigh to avoid tag loss through the incision and to allow for tags to be viewed through transparent skin (Chelgren 2003). I manually restrained captured frogs and kept the legs and arms stationary. I recorded SVL and sex prior to release at the exact location of capture. In addition, I determined and recorded the same meso and microhabitat data as the VES.

\section{Radiotelemetry}

I attached radio transmitters (Holohil Systems Ltd.; BD-2 transmitters) weighing $0.90-1.20 \mathrm{~g}$ to five large adult foothill yellow-legged frogs weighing at least $15 \mathrm{~g}$ (Mathews and Pope 1999; Watson et al. 2003) between early June 2005 and mid October 2005, after breeding frogs regained and stabilized their weight. Initially, my goal was to fit transmitters to frogs in late winter before breeding in order to track them to the breeding area. However, heavy rains and high flows prevented me from capturing frogs in winter. I used a custom fitted bead chain (key chain) to attach transmitters (Mathews and Pope 1999; Ritson and Hayes 2000; Goldberg et al. 2002). The combined weight of the transmitter was $1.5 \mathrm{~g}$ to satisfy the ten percent rule of transmitter to body weight, thus minimizing the effects of the transmitter on the frogs (Mathews and Pope 1999; Watson et al. 2003). 
I captured five frogs (three females $>30 \mathrm{~g}$ and two males $>20 \mathrm{~g}$ ) to be fitted with radio transmitters by hand or dip net, and restrained them by hand without anesthesia. Frogs were released as soon as they recovered after attachment of radio transmitters to the exact location of initial capture. I recorded the same meso and microhabitat data for vi alpha marked frogs, determined sex, and measured SVL. Frogs were tracked simultaneously with VES. I tracked frogs at least twice weekly using a tectonics receiver with a hand held H-flex antenna (Ritson and Hayes 2000). I recovered the radio transmitter apparatus from all frogs between mid-October 2005 and 16 November 2005. Battery life of these transmitters was 16 to 20 weeks. I determined distances traveled from the last location by noting the exact mesohabitat with predetermined distances from a known landmark and measured locations from the top or bottom of the habitat. Tracked frogs were located twice daily, first in the morning and later in the late afternoon.

\section{Stream Flow}

Daily and hourly stream flow data were retrieved from U.S. Geological Survey (USGS) Station Number 111698800 on Coyote Creek upstream of Coyote Reservoir and downstream of Henry Coe State Park. The gauge is about midway through the downstream reach and about $20 \mathrm{~m}$ downstream of the confluence of Dexter Creek and the main stem of Coyote Creek. This station was inoperable during 2004. As a consequence, I used data from a nearby watershed (Lower Llagas Creek) within the Gilroy, California city limits. I retrieved these data from USGS station number 1153650 to determine storm runoff. 


\section{Temperature}

Stream temperatures were recorded daily at one hour intervals from January 2005 to fall 2005, using Optic Stowaway temperature loggers in degrees Celsius $\left({ }^{\circ} \mathrm{C}\right)$. Loggers were housed in steel plumbing joints and chained to objects unlikely to move at high flows. I installed loggers at four locations within the study area. Two locations were at the upper and lower ends of the study area and two were located nearly evenly-spaced between them. In addition, temperature loggers were installed in perennial pools on Dexter Creek and on the unnamed tributary below Sheep Ridge. Both tributaries were occupied by adult foothill yellow-legged frogs throughout the year. I used a hand held thermometer to take spot temperatures during the initiation of breeding in 2004 and 2006. I did not have access to temperature loggers during 2004 and 2006.

\section{Analyses}

I ran ANOVA and unpaired two sample t-tests for a comparison between 2004 and 2005 for depth of egg mass deposition, distance from shore of breeding, and attachment substrate sizes. MYSTAT 12, a student version of SYSTAT 12 and SYSTAT 13, was used to test assumptions of equal variances, sample means, and to calculate $\mathrm{R}^{2}$ for linear regressions. Comparisons of average maximum distances traveled by season were made between all frogs, all adults, adult males versus females, and adults versus juveniles. Unpaired two-tailed t-tests were employed in instances in which the null hypothesis was accepted for equal variances. The Wilcoxon test for equal sample means was used in one instance where the null hypothesis for equal variances was rejected (adults versus juveniles). The Von Bertalanffy Growth Equation (VBGE) was used to produce 
predictive growth curves for small $(17 \mathrm{~mm})$ and large $(22 \mathrm{~mm})$ metamorphs, and was compared with metamorph growth on the Feather River during 2004 (S. Kupferberg Personal Communication). Condition factors were calculated for resident adult main stem and tributary frogs using the equation $\mathrm{K}=\mathrm{W}^{*} 100 / \mathrm{L}^{3}$, where $\mathrm{K}$ is the condition factor, W is the weight in grams, and L is length in centimeters (Moyle and Cech 1996). I performed chi squared tests for goodness of fit for mesohabitat preference as well as mesohabitat substrate dominance use/preference of adult foothill yellow-legged frogs from the cessation of breeding to the summer dry back of the channel. I used both t-tests and non-parametric tests of significance for adult foothill yellow-legged frog mean and maximum depths, mean canopy, and mean number of cover types (cover complexity). 


\section{RESULTS}

\section{General Breeding Pattern}

The lower and upper breeding sites (upper and lower reaches) were separated from one another by $4 \mathrm{~km}$ (2.5 miles) of the middle reach (Figure 1), where no breeding was detected in 2004 and 2005. A total of 72 egg masses were deposited for the two sites during 2004, with a combined density of 0.0149 masses/m (Table 1 ).

Breeding increased at both sites in 2005, with 103 egg masses deposited and a density of $0.0214 \mathrm{mass} / \mathrm{m}$. Breeding started slightly later, and lasted much longer at both sites during the wetter 2005. Start of breeding was checked only at the lower site in 2006 and was three days earlier in 2006 than in 2005 and two days later than 2004. Breeding initiation in all three years occurred as temperatures were close to $12^{\circ} \mathrm{C}$ and as flows declined to between $22-27 \mathrm{cms}(72-88 \mathrm{cfs})$ during 2005 and 2006 on the lower reach.

Hatching success (as egg mass survival) decreased on the lower reach from 100 percent in 2004 to 73 percent in 2005 (Table 2). This was due to scour of masses from a particularly intense storm during late March. Egg mass survival at the upper reach was 100 percent in both years. The mean number of days for eggs to hatch was similar on the lower reach between $2004($ mean $=13)$ and $2005($ mean $=12)$, but the range in 2005, with the longer breeding season, was much higher (6-26 days versus 10-14 days; Table 2). The mean number of days to hatching on the upper reach in 2005 was slightly higher than at the lower reach (14 versus 12), and the range was narrower (8-19 versus 6-26). Average egg mass diameter was smaller in 2005 on both reaches. Egg masses became 
smaller as the breeding season progressed (Figures 2 and 3). In 2005, mean clutch size for both reaches combined was $60 \mathrm{~mm}$ during the first third of the breeding season, 43 $\mathrm{mm}$ during midseason and $29 \mathrm{~mm}$ during the last third of the season. An ANOVA comparing three means showed these differences between early, mid- and late-season clutch sizes to be significant using (Levene's Test; $\mathrm{df}=2,100, \alpha=0.025$, critical $\mathrm{F}=3.83$, calculated $\mathrm{F}=4.871$ ). A regression for egg mass diameter by date, yielded $\mathrm{R}^{2}$ values of 0.684 for the lower reach and 0.728 for the upper reach in 2005 .

The mean depth at which eggs were deposited was significantly deeper during 2005 $(0.237 \mathrm{~m})$ than in $2004(0.157 \mathrm{~m})$ (unpaired two sample t-test; $\alpha=0.025, \mathrm{df}=173$, critical $t=1.974$ and calculated $t=-3.056$ ). Egg deposition was closer to the edge of the wetted channel in $2005(2.201 \mathrm{~m})$ than $2004(2.636 \mathrm{~m})$. However, the distance was not significantly different because of wide variation in both years (unpaired two sample ttest; $\alpha=0.025, \mathrm{df}=173$, critical $\mathrm{t}=1.974$ and calculated $\mathrm{t}=2.166$ ). Egg attachment substrates were larger during $2005(68 \mathrm{~mm})$ than $2004(59 \mathrm{~mm})$, but were not statistically significant (unpaired two sample $\mathrm{t}$-test; $\alpha=0.025, \mathrm{df}=165$, critical $\mathrm{t}=1.974$ and calculated $\mathrm{t}=-0.455)$.

\section{Stream Flow and Breeding}

Breeding initiation occurred within 10 days after the last significant storm on both reaches in 2004 (Figures 4 and 5). All egg masses were deposited on the descending limbs of the hydrograph generated by the latest storm. Stable spring base flows of approximately $2.44 \mathrm{cms}$ (8 cfs) were reached by early April 2004 (Figure 6). In contrast, in 2005 stable spring base flows gradually decreased through late April, but there was 
also an early May storm of $53 \mathrm{cms}$ (174 cfs) (Figure 7). Breeding was initiated on about 21 March 2006 on the lower reach after a storm. I spot-checked the water temperature, which was $11.5^{\circ} \mathrm{C}$ at 10:30 AM. There was a large storm with measured discharges as high as $500 \mathrm{cms}$ (1700 cfs) in early April, 2006 that likely scoured egg masses, but an explosion of breeding occurred on the lower reach by April 10 .

Stream flows varied between 4.88 and $405 \mathrm{cms}$ (16-1,330 cfs) during the breeding season in 2005. However, the highest mean daily discharge recorded during a day that breeding occurred was $23.5 \mathrm{cms}$ ( $77 \mathrm{cfs}$ ). Breeding initiation in 2005 occurred within a week by calendar date compared with 2004, despite the drastically different flows between the two years. Nine of eleven early egg masses deposited at the lower site during 2005 were scoured by consecutive large storms that lasted about ten days in March. Flows increased three more times during the breeding season, due to moderatesized storms that persisted into early May. All egg masses on both reaches were deposited on descending limbs of the hydrograph during 2005. No egg masses were deposited within the upper reach prior to the large storms in late March.

\section{Temperature and Breeding}

No temperature data were collected to calculate daily means, minimums, and maximums during the 2004 breeding season. However, hand held thermometer readings were recorded when new egg masses were encountered, and temperatures were always greater than $12^{\circ} \mathrm{C}$. I measured $11.5^{\circ} \mathrm{C}$ water temperature on the morning of 21 March 2006, when I observed the first egg masses that were less than 2 days old. Mean daily temperatures were likely over $12^{\circ} \mathrm{C}$. The lowest daily mean water temperature recorded 
on a day when breeding occurred was $11.3^{\circ} \mathrm{C}$ on 4 April 2005 on the upper reach. Mean daily temperatures exceeded $12^{\circ} \mathrm{C}$ on the lower reach by 1 March 2005 . However, breeding was not initiated until 12 March 2005. The majority of egg masses (72 of 103) in both reaches, including early March on the lower reach, were deposited during days when daily mean water temperatures ranged between 13 and $17^{\circ} \mathrm{C}$ (Figures 8 and 9). In 2006, the first egg masses were deposited on 9 March on the lower reach, at a temperature of $12.2^{\circ} \mathrm{C}$. No breeding occurred in 2004 or 2005 on days when daily mean temperatures exceeded $19.3^{\circ} \mathrm{C}$.

\section{Physical and Habitat Parameters for Egg Masses}

Mesohabitat Use.-Breeding took place within seven pool habitats and one run during 2004 on the lower reach (Table 3). Two different pools were utilized for breeding in 2005. The new pools used in 2005 were immediately downstream of the downstreammost pool used in 2004. All mesohabitats utilized for breeding during both years held water until at least August and were either perennial mesohabitats or were adjacent to one. About half of the egg masses during both years (54 of 100) were deposited near the tail of breeding pools, most of the rest (41 of 45 ) were near the middle and one was deposited at the head of a pool (Table 4). Breeding took place in eight pool habitats during both years on the upper reach (Table 3), but three of the pools were different between years. The new pools used in 2005 were adjacent to the pools used in 2004 . Over three-quarters (24 of 31) of the egg masses in 2004 were deposited near the tail of breeding pools (Table 4). In contrast, frogs predominately chose the middle of pools (33 
of 44) over the tailouts for breeding during 2005. All mesohabitats on the main stem that held water until at least August were used for breeding

Microhabitat Use.-Submerged gravel bars were the most frequently-chosen areas of pools during both years at both sites. However, there was a significant increase in use of cobble bars at the lower site during 2005 (Table 4). At the upper site, cobble bar use declined in 2005, and some frogs (5\%) used deeper slack water in 2005.

All egg masses at the lower reach during 2004 were attached to stones (Table 5). However, five egg masses $(8 \%)$ were attached to vegetation or roots in 2005 . The majority of egg masses deposited on stones during both years was deposited on gravel (5-75 mm) substrates. In the upper reach, all egg masses during both years were attached to stones, with an increase in the use of cobbles (Table 5). The majority (70-83\%) of egg masses during both years were deposited on gravel substrates. There was an increase in the use of cobble (17 to 30\%) for attachment during 2005 when stream flows were higher.

In the lower reach, oviposition occurred in deeper water and somewhat closer to shore in 2005, but egg masses had lower canopy closure in 2004 than 2005 (27 and 31 percent; Table 6). In the upper reach, oviposition occurred in deeper water $(0.24 \mathrm{~m}$ versus $0.19 \mathrm{~m})$ and somewhat closer to shore $(2.59 \mathrm{~m}$ versus $3.18 \mathrm{~m})$ and at locations with more open canopies in 2005 in comparison to 2004 (18 versus 32 percent; Table 6).

\section{Movement/Mark and Recapture}

General Characteristics.-A total of 181 frogs of all ages were marked during 20042005. This included 106 males, 67 females and eight undeterminable frogs, for a male- 
to-female ratio of 1.58. A total of 106 frogs were recaptured at least once, and 65 individual frogs were recaptured at least twice. The observed male-to-female sex ratio during the 2005 breeding season was 1.48 on the lower reach and 1.85 on the upper reach.

A total of 58 juvenile frogs were marked during 2004-2005. All juveniles marked during 2004 were young of the year, and in 2005 all were yearling frogs that overwintered. Four female and nine male juveniles first captured as juveniles were recaptured as adults (Table 7). Snout to vent length $(\mathrm{mm})$ and mass $(\mathrm{g})$ ranges for both adult males and females were very similar between 2004 and 2005. Maximum weight of females was nearly twice that of males throughout the study area during both years (Table 8). Most (87 percent) lower reach adult females resided on Dexter Creek outside of the breeding season during both 2004 and 2005 (Table 9). Nearly two-thirds of lower reach adult males captured during 2005 resided on Dexter Creek. However, few males (n =3) were captured in 2004 and only one was captured on Dexter Creek.

The number of frogs observed and captured on the lower reach breeding site started to increase as temperatures reached about $10^{\circ} \mathrm{C}$ in mid-February and peaked starting in mid-march through mid-May 2005. Observations of adult frogs on the lower reach declined soon after breeding ceased in mid-May, and few frogs were seen after mid-June (Figure 10). The number of males observed outnumbered females during the majority of the time, especially prior to and after active breeding occurred (Figure 11).

The upper reach has a perennial tributary (Long Canyon Creek) with resident foothill yellow-legged frogs, similar to Dexter Creek. These frogs are likely to breed on the 
upper reach and make significant movements to and from the main stem. However, I did not include this tributary as part of my visual encounter surveys and mark and recapture because there were illegal marijuana gardens with armed guards throughout this study.

Movement.-Patterns of movement among foothill yellow-legged frogs in the Coyote Creek watershed were highly seasonal and associated with breeding. Over ninety percent of marked frog movements were either to the breeding area or away from it after breeding. Few frogs stayed in one location during both the pre-breeding and breeding seasons spanning February through May (Figure 12). In contrast, nearly half of the marked frogs did not move during the non-breeding season, June through January. Fourteen percent made very small movements to adjacent mesohabitats. Movements to adjacent habitats were generally either between pools and riffles, or from one step pool to another. All non-breeding season movements were made in response to either channel dry backs or rain events. The maximum distance traveled by any frog was just under 2,500 m during spring 2005 (Figure 13). This frog was an adult female moving from the main stem breeding area to her residential habitat in an unnamed tributary below Sheep Ridge after breeding. She was initially captured and marked on 10 April 2005, and last recaptured on 29 June 2005. The maximum distance traveled by an adult male was more than 2,200 m. This frog moved from its residential habitat on Dexter Creek to the breeding area during early spring 2005 . The maximum distance traveled by a juvenile frog was about $860 \mathrm{~m}$ during the pre-breeding/breeding season. This frog moved from the main stem of Coyote Creek upstream into Dexter Creek. Diurnal daily movements of 
radio-tracked frogs during summer ranged between 0 to $4 \mathrm{~m}$. The average movement was less than $0.3 \mathrm{~m}$.

Maximum distances traveled by all frogs (total marked frogs recaptured) during the pre-breeding/breeding season were significantly greater than the non-spawning season (paired 2-tailed t-test; critical $\mathrm{t}=-4.619$, calculated $\mathrm{t}=-4.205, \mathrm{p}=0.001$ ). Mean maximum distances traveled by all frogs during the pre-breeding season were $543 \mathrm{~m}$ and were $104 \mathrm{~m}$ during the non-breeding season. Distances traveled by adults during the prebreeding/breeding season $(593 \mathrm{~m})$ were significantly greater than in the non-breeding season $(107 \mathrm{~m})($ paired 2-tailed $\mathrm{t}$-test; critical $\mathrm{t}=-4.727$, calculated $\mathrm{t}=-4.029, \mathrm{p}=0.001)$. Wide individual variation in movement overwhelmed mean differences among groups. Maximum distances traveled by females (744 m) during the pre-breeding/breeding season were substantially greater than males $(485 \mathrm{~m})$, but the difference was not significant (paired 2-tailed t-test; critical $\mathrm{t}=-1.107$, calculated $\mathrm{t}=-1.039, \mathrm{p}=0.277, \alpha=$ 0.05). Mean maximum distances traveled by adults during the pre-breeding season were about twice that of juveniles (593 m versus $305 \mathrm{~m}$ ), but the difference was not significantly different (non-parametric Kruskal-Wallis; critical $t=1.090$, calculated $t$ $=1.593, \mathrm{p}=0.286, \alpha=0.05)$. The magnitude of breeding season movements of female and male tributary residents was generally greater than main stem resident frogs (Figures 14-17). Resident tributary females occupied habitats that were generally farther away from the main stem than resident tributary males during the non-breeding season. Most frogs of both sexes generally moved little or not at all on both the main stem and tributary during the non-breeding season. However, movements were made during the 
non-breeding season in response to dry backs and two rain events during the summer of 2005 (Figures 14-17).

Radiotracking Efficiency.- Individual marked frogs were repeatedly recaptured on Dexter Creek during radio-tracking surveys, with 37 captured during 117 surveys (Table 10). Detectability of marked, stationary non-radiotagged frogs varied between 12 and 67 percent for individual frogs, and averaged 32 percent (Table 10). Nearly all detected non-radiotagged frogs detected were basking (Figure 18). In contrast, as a result of 100 percent detectability, one-third of radiotagged frogs were found under substrate and onequarter were underwater, where non-radiotagged frogs were rarely detected (Figure 18).

Nearly three-quarters of both radiotagged and non-tagged frogs were observed on the bank (Figure 19). Observed non-tagged frogs were primarily on cobble and gravel bars or on exposed cobbles and boulders on Coyote Creek (Figure 20). In the steeper channel of Dexter Creek they were primarily on boulders ( 75 percent). There was less use of cobble and gravel bars (5-10 percent). Nearly 60 percent of radiotagged frogs in Dexter Creek were near the head of the pool (Figure 21). However, the majority nonradiotagged frogs were in the more visible habitat in the middle of the pool (Figure 21), where more open basking habitat was present (Figure 18).

Growth.-Predicted growth curves from the Von Bertalanffy Growth Equation (VBGE) produced by recaptured frogs showed frogs on Coyote Creek reached near minimum adult size $(40 \mathrm{~mm})$ by the end of their first year. I repeatedly sampled six pools (with approximately 200 young of the year frogs) within both breeding sites during mid to late October 2004. Observed daily growth rates varied widely, but were generally 
higher than predicted daily growth rates (Figure 22). Observed growth rates from selected adult females were most similar to smaller $17 \mathrm{~mm}$ transformation predicted growth curves (VBGE). Males and females exhibited their highest growth rates as subadults and small adults less than $50 \mathrm{~mm}$ (Figure 23). Female foothill yellow-legged frog growth in length ceased after they reached about $70 \mathrm{~mm}$ on Coyote Creek. Females 70 $\mathrm{mm}$ SVL or larger needed at least three years to reach this length. Females that were near or less than $40 \mathrm{~mm}$ during spring 2004 were on trajectory to finish their second year near $50 \mathrm{~mm}$ (Figure 24). I captured a female that measured $36 \mathrm{~mm} \mathrm{SVL}$ on 24 September 2004 and recaptured her when she measured $51 \mathrm{~mm}$ on 15 July 2005. Male foothill yellow-legged frog growth substantially slowed soon after they exceeded $50 \mathrm{~mm}$; size topped out near $55 \mathrm{~mm}$. Males that started spring 2005 between 30 and $40 \mathrm{~mm} \mathrm{SVL}$ could reach $50 \mathrm{~mm}$ by the end of the year (Figures 25 and 26).

Condition factors for adult female tributary residents (mean $=11.7 ; \mathrm{n}=58$ ) were significantly greater than those who resided on the main stem $($ mean $=11.2 ; \mathrm{n}=44)$ (calculated $\mathrm{t}=-2.539$, critical $\mathrm{t}=1.984, \alpha=0.05, \mathrm{p}=0.013$ ). However, condition factors were slightly less than significantly different between resident main stem and tributary resident frogs when all frogs were included (calculated $t=-10854$, critical $t=1.97, \alpha=$ $0.05, \mathrm{p}=0.065)$

\section{Habitat Mapping}

Available Habitat.—A total of $8.56 \mathrm{~km}(28,013 \mathrm{ft} ; 5.3 \mathrm{mi})$ of habitat was typed on the main stem of Coyote Creek from the high water mark at the inlet to Coyote Reservoir to the last perennial pool associated with the upper reach breeding site below Gilroy Hot 
Springs. The lower and upper reaches represented two distinct breeding sites that comprised all habitats used for breeding and rearing within the study area. The middle reach separated the lower and upper reaches, and contained no suitable breeding habitat for foothill yellow-legged frogs. Surface flows were not observed anywhere on this reach after July during 2003-2006. This reach was completely contained within a short, wide alluvial valley that separates the intermittent/perennial habitats of the lower and upper reaches. In addition, $1.15 \mathrm{~km}(7,020 \mathrm{ft} ; 1.33 \mathrm{mi})$ of Dexter Creek an intermittent stream, was mapped from the confluence with the main stem of Coyote Creek to the farthest upstream perennial pool.

Lower Reach.-The lower reach stretched $2.38 \mathrm{~km}(7,797 \mathrm{ft} ; 1.47 \mathrm{mi})$ from the high water mark of Coyote Reservoir upstream past the confluence with Dexter Creek to the downstream terminus of the alluvial valley. The channel morphology was almost all Rosgen Level II C Channel, and was slightly entrenched, highly sinuous, with a moderate to high width/depth ratio (Rosgen 1996) (Figure 27). There was a small section associated with the Dexter Creek confluence that was a B channel, and was moderately entrenched, moderately sinuous, with a moderate to high width/depth ratio. Threequarters of the mesohabitat composition consisted of pools separated by riffles and flatwater (Figure 28). Habitats in the reach had a mean width of $5.8 \mathrm{~m}(19 \mathrm{ft}$ ), with pools having the widest and deepest habitats. Open canopies were typical on the lower reach with a mean of 20 percent canopy closure (Table 11). Cobble and gravel were the usual dominant (41-43 percent) and sub-dominant (32-38 percent) substrates (Table 12). Substrate (98 percent) and aquatic vegetation (algae; 83 percent) were the most common 
escape covers, but pools had a relatively high cover complexity, including depth (51 percent), undercut banks (19 percent), rootwads (19 percent), and large wood (14 percent) (Table 13).

Middle Reach.-The middle reach stretched $3.7 \mathrm{~km}(12,149 \mathrm{ft} ; 2.3 \mathrm{mi})$ through a wide, short alluvial valley to the head of the valley. The channel morphology throughout the reach was a Rosgen Level II C Channel (Figure 27), and was slightly entrenched, highly sinuous with a moderate to high width/depth ratio (Rosgen 1996). Slightly more than half of the mesohabitat composition consisted of pools separated by long riffles (turbulent) and runs (flatwater) (Figure 28). The reach had a mean width of $5.8 \mathrm{~m} \mathrm{(19} \mathrm{ft),}$ with pools having the widest and deepest habitat. Canopies were generally open on the middle reach with an average of 17 percent canopy (Table 11). Gravel was the dominant (34-64 percent) and cobble the sub-dominant (20-35 percent) substrate, although boulder was also an important subdominant (33 percent) (Table 12). Substrate (99 percent) and aquatic vegetation/algae (50 percent) were the most common escape covers, but pools had a relatively high cover complexity (variety of cover types), including depth (44 percent), rootwads (44 percent), and large wood (15 percent). However, the overall escape cover complexity of pools and overall reach total cover were lower than in the lower and upper reaches (Table 14).

Upper Reach.-The upper reach stretched $2.47 \mathrm{~km}(8,067 \mathrm{ft} ; 1.5 \mathrm{mi})$ from the head of the alluvial valley to the last perennial pool associated with the upper breeding site below Gilroy Hot Springs. The channel morphology was nearly two-thirds Rosgen Level II C Channel, and slightly entrenched, highly sinuous, with a moderate to high width/depth 
ratio. The rest was $\mathrm{B}$ channel, and moderately entrenched, moderately sinuous, with a moderate to high width/depth ratio (Figure 27). Over three-quarters of the mesohabitat composition consisted of pools, separated by relatively short riffles (turbulent) and runs (flatwater) (Figure 28). The reach had a mean width of $5.2 \mathrm{~m}(17 \mathrm{ft})$, with pools having the widest and deepest habitat. Canopy coverage (46 percent) was over twice that of the lower and middle reaches (Table 11). Gravel and cobble were the most common dominant (31-40 percent) and sub-dominant (23-46 percent) substrates, with sand a common dominant (28 percent), and boulders a common sub-dominant (28 percent) substrate (Table 12). Substrate (100 percent), overhanging trees (64 percent), and overhanging grass/sedges (63 percent) were the most common escape covers. Pools had a relatively high cover complexity, as in the lower reach (Table 13).

Dexter Creek.-Dexter Creek was mapped $2.15 \mathrm{~km}(7,020 \mathrm{ft} ; 1.33 \mathrm{mi})$ from the confluence with the main stem on the lower reach to the farthest upstream perennial pool. The channel morphology was almost three-quarters Rosgen Level II B Channel, and moderately entrenched, moderately sinuous, with a moderate to high width/depth ratio (Rosgen 1996). Almost one-fifth of the stream consisted of G channel, and was deeply entrenched, with a low width/depth ratio, sinuous, with a gullied appearance. This channel type existed mostly near the confluence with the main stem. The rest consisted of A Channel, and steep, deeply entrenched, with low sinuosity, and low width/depth ratio (Figure 27). Over eighty percent of the mesohabitat composition consisted of turbulent (riffles and cascades) and flatwater (step runs) (Figure 28). Less than one-fifth of the reach consisted of pool habitat. The reach had a mean width of $2.2 \mathrm{~m}(7.2 \mathrm{ft})$, and 
pools had the narrowest and deepest habitat. Canopy was generally closed on Dexter Creek, with an average of 91 percent canopy (Table 11). Boulder was the most common dominant (23-53 percent) and cobble the most common sub-dominant (38-48 percent) substrate, with gravel as a common dominant (24 percent) (Table12). Substrate (99 percent) and surface turbulence (73 percent) were the most common escape covers, with pools also providing cover as depth (87 percent), and undercut banks (16 percent). Dexter Creek habitats had lower cover complexity than the main stem reaches (Table 13).

\section{Mesohabitat Use and Preference}

Adult foothill yellow-legged frogs used mesohabitats on the main stem which were strongly associated with breeding habitats and mesohabitats on the tributary (Dexter Creek) that were in or near perennial pools. I used data from both VES and mark and recapture to determine mesohabitat preferences for adult frogs. The data used were collected from 2004 (20 April to 1 July) and 2005 (18 May to 25 July) between the cessation of breeding and loss of total aquatic connectivity due to dry backs. Mesohabitat use and preferences for juvenile frogs were not analyzed because young of the year frogs used only their natal habitat (Table 3) and the 2004 cohort measured over $40 \mathrm{~mm}$ by the cessation of breeding in 2005

Main Stem.-Adult frogs heavily used pools, compared to their availability, and under-utilized turbulent mesohabitats (Table 14). Adult females used and preferred both pools (62 percent) and flatwater ( 20 percent) over turbulent habitats (chi square goodness of fit test; $v=2, \alpha=0.05$, critical $X^{2}=5.99$, calculated $X^{2}=6.52$ ). Adult males preferred and used pools (72 percent) more than females, and did not prefer flatwater mesohabitats 
( 9 percent) in comparison to flatwater (11 percent) habitat availability (chi square goodness of fit test; $v=2, \alpha=0.05$, critical $X^{2}=5.99$, calculated $X^{2}=12.3$ ). Both males and females avoided mesohabitats dominated by sand, and preferred those that were dominated by boulders in comparison to availability (Table 15). Adult females strongly preferred mesohabitats dominated by boulders (50 percent) (chi square goodness of fit test; $v=4, \alpha=0.05$, critical $X^{2}=9.48$, calculated $X^{2}=408$ ). Males used mesohabitats dominated by gravels and cobbles in proportion to their availability (Table 15), but used and showed a preference for boulder dominated mesohabitats (chi square goodness of fit test; $v=4, \alpha=0.05$, critical $X^{2}=9.48$, calculated $\left.X^{2}=182\right)$. Females ( $0.63 \mathrm{~m}$; unpaired t-test; $\alpha=0.05, p=0.010)$ and males $(0.68 \mathrm{~m}$; unpaired t-test; $\alpha=0.05, \mathrm{p}=0.140)$ used deeper mesohabitats compared to availability $(0.45 \mathrm{~m})$, but the difference was significant only for females (Table 17). Adult females preferred mesohabitats a little shadier (43 percent) than what was available (36 percent) (unpaired t-test; $\alpha=0.05, p=0.047$ ), but males did not prefer shadier mesohabitats. Males used mesohabitats with an average cover complexity about equal to that which was available on the main stem, but females strongly preferred mesohabitats with higher (4.3) cover complexity (Table 16) than males (3.4) in comparison to availability (unpaired t-test; $\alpha=0.05, \mathrm{p}=0.001$ ).

Dexter Creek.—Adult foothill yellow-legged frogs used pools 97 percent of the time on Dexter Creek, although pools made up only 52 percent of available habitat (Table 14). Both females (chi square goodness of fit test; $v=2, \alpha=0.05$, critical $X^{2}=5.99$, calculated $\left.X^{2}=106\right)$ and males $\left(v=2, \alpha=0.05\right.$, critical $X^{2}=5.99$, calculated $\left.X^{2}=188\right)$ strongly preferred pools (Table 14). Adult females preferentially used mesohabitats 
dominated by boulder substrate ( 70 percent) and used few dominated by cobble or gravel $\left(v=4, \alpha=0.05\right.$, critical $X^{2}=9.49$, calculated $\left.X^{2}=408\right)$. Similarly, males preferentially used boulder dominated mesohabitats (63 percent), but also showed a preference for mesohabitats that were gravel dominated (34 percent) compared to availability ( $v=4, \alpha$ $=0.05$, critical $X^{2}=9.49$, calculated $\left.X^{2}=182\right)($ Table 15). Adult females used pools that were deeper $(0.46 \mathrm{~m})$ than males $(0.37 \mathrm{~m})$, but both females and males preferred deeper mesohabitats $(0.42 \mathrm{~m})$ than those available $(0.25 \mathrm{~m})$ (unpaired t-test; $\mathrm{p}=<0.001)$ (Table 16). Adults of both sexes, used mesohabitats with significantly less canopy cover (85-87 percent) than available (91 percent) (unpaired t-test; $\alpha=0.05, p=<0.001$ ). Females and males used and preferred mesohabitats that had relatively more complex escape cover (3.75) than what was available (2.4) (unpaired t-test; $\mathrm{p}=<0.001)$ (Table 16).

\section{Predators}

I recorded 516 observations of potential diurnal predators during 2004-2005 within the study area, which included all main stem reaches and Dexter Creek. The overwhelming majority of diurnal predator observations (470) were recorded on the main stem. Santa Cruz garter snakes (Thamnophis atratus atratus) made up the majority of observations, but birds and larger ranid species were also commonly observed on the main stem (Figure 29). Common mergansers (Mergus merganser) comprised over 80 percent of the potential avian predators observed on the main stem. California red-legged frogs were overwhelmingly (93 percent) the most encountered potential predators on Dexter Creek. The only other predator observed on Dexter Creek was Santa Cruz garter snake, which was scarce. Based on observations made prior to the study, American robins (Turdus 
migratorius) were highly skilled at capturing foothill yellow-legged frog metamorphs, Pacific chorus frogs, and western toads (pers. observ.). 


\section{DISCUSSION}

\section{Breeding}

Timing of breeding initiation was similar during 2004, 2005, and 2006, despite the vast difference in stream flows during 2004, 2005, and 2006. This suggests that photoperiod could be a strong cue for breeding initiation. However, breeding initiation on nearby Alameda Creek was 13 days later in 2005 than 2004 (Kupferberg et al. 2009). This difference may be due to lower water temperatures in 2005 than in 2004. Conditions in 2004 were drier than average in the Santa Clara Valley. Four rain gauge stations had between 73 and 88 percent of average readings for the year. In contrast, 2005 and 2006 were very wet years, with ranges from 125 to 174 percent of average in 2005, and 112 to 165 percent of average in 2006. Stable spring base flows were not reached until late May in 2005 and 2006. Populations may complete breeding within a two week period (Storer 1925; Zweifel 1955), suggesting foothill yellow-legged frogs can be explosive breeders. However, this study and one conducted on Hurdygurdy Creek (Wheeler and Welsh 2008) had wide variability in length of breeding season among years. This suggests foothill yellow-legged frogs may be prolonged breeders instead. Wheeler and Welsh concluded that initiation and length of the breeding season were strongly influenced by the natural hydrologic cycle, which may vary greatly among years. This appears to be the case on Coyote Creek, where temperatures at the initiation of breeding were close to $12^{\circ} \mathrm{C}$ in all three years on Coyote Creek. This is consistent with most other studies, but at the low end of the range compared to North Coast Range, 
Sierra Nevada, and Cascade Range foothill streams (Zweifel 1955; Kupferberg 1996; Fuller and Lind 1991; Seltenrich and Pool 2002; Placer County Water Agency 2008). In Coyote Creek, temperatures are higher than northern or mountain foothill streams at the time stream flows normally begin to decline.

The loss of 16 early, large $(50-85 \mathrm{~mm})$ egg masses on the lower reach in 2005 was partially mitigated by a net gain of 19 egg masses during the extended breeding season at the lower site that year. However, 11 of these late egg masses were less than $40 \mathrm{~mm}$ in diameter. Therefore, there were fewer eggs surviving to hatching in 2005 than in 2004 on the lower reach. The upper reach had a net gain of 13 egg masses, and all masses deposited in the upper reach survived to hatching in 2005. In Alameda Creek there also was a substantial gain in overall breeding output in both 2005 and 2006, in comparison to 2004 (Kupferberg et al. 2009). The higher stream flows and favorable temperature that allowed an extension in the breeding season compared to 2004, likely allowed for enough time for smaller yearling females to mature, and contribute to the 2005 cohort on Coyote Creek. Fifteen egg masses deposited late during the breeding season were less than 30 $\mathrm{mm}$ diameter in 2005, but the smallest egg mass deposited during 2004 was $38 \mathrm{~mm}$. Van Wagner (1996) recorded an egg mass size range of 35-70 mm on Clear Creek in Nevada County during 1992, 1993, and 1994, and all breeding frogs were at least two years old. The breeding season on Coyote Creek was much longer on both the lower and upper reaches in 2005 than in 2004. The much wider range of breeding temperatures resulted in a wider range of the number of days it took for eggs to hatch at the lower reach in 2005. 
Stream Flow and Breeding.-All breeding occurred on descending limbs of the hydrograph and at flows less than an order of magnitude (25-30 cms [80-100 cfs]) higher than spring base flows $(2.4-3.0 \mathrm{cms}$ [8-10 cfs] $)$. There was one significant descending limb of the hydrograph in 2004 and four in 2005 because of late storms during breeding in 2005. Peak stream flows were much higher in 2005 and 2006, but initiation of breeding took place within a week of each other in 2004, 2005, and 2006. It appears that magnitude of flows during the breeding season had limited effect on initiation and breeding activity on Coyote Creek during 2004-2006. Suitable breeding habitat is available at a range of stream flow levels. Seventeen years of monitoring on the South Fork Eel River by Kupferberg et al. (2009) showed only a weak trend toward breeding later in the year during wet years. They concluded timing of breeding was not associated with stage heights. Decreasing flows from storm induced peaks (descending limbs) were strongly associated with breeding activity on Coyote Creek, but breeding activity temporarily ceased when flows increased due to storms within the breeding season. Rain may suppress breeding activity once adult frogs reach the breeding locations (Kupferberg 1996a).

Large spring storms that create high magnitude stream flows have a potential to scour egg masses deposited early in the breeding season. The large storms during late March and early April in 2005 created high flows (427 cms [1,400 cfs]) that scoured nearly all egg masses deposited in March. A large late season storm that occurred in 2006 at the end of March, and lasted into the middle of the first week of April, generated peak flows as high as $(518 \mathrm{cms}[1,700 \mathrm{cfs}])$. Although the fate of egg masses was not studied in 
2006, most egg masses and newly hatched tadpoles present prior to the late storm were likely lost to scour. The larger egg masses during the early part of the breeding season, indicates that early breeding by the largest females is a risky strategy during wet years such as 2005 and 2006. Similar losses of egg masses from scouring flows due to intense late season storms and dam spillovers were documented on the Trinity River (Lind et al. 1996) and on the South Fork Eel River due to storms during 2005 (Kupferberg et al. 2009). The advantage of early breeding is likely to be that in most years the flows are too low to scour egg masses, resulting in increased time, and probability for recruitment to adulthood compared with eggs deposited later in the season, especially in drier watersheds such as Coyote Creek. Larger, older tadpoles likely out-compete smaller, younger tadpoles, especially during drier years.

A plastic reproductive strategy has likely allowed this species to persist in the fluctuating climatic pattern of California, which alternates unpredictably between wet and very dry. Between 1961 and 2006, there have been eight seasons in which high scouring flows (> $305 \mathrm{cms}[1,000 \mathrm{cfs}])$ occurred after March 15 . These were mostly El Niño years such as $1963,1964,1965,1982,1998,2005$, and 2006 . The only exception was 1991, which was generally a very dry year, but with a large storm during late March. Large magnitude, late season storms tended to be spaced over the years. The occasional risk to the largest, most fecund females for breeding early is relatively low over the lifetime of these individuals. Smaller females tend to breed later when the hydrograph is more stable after mid-April in central California, but part of that may be due to growth to breeding size during prolonged breeding seasons. All breeding habitats in Coyote Creek 
were perennial or adjacent to perennial habitat during all years, including the driest of years. If they successfully transform, young of the year frogs did not have to move far to find water when the habitat they were in dried.

Temperature and Breeding.--There appears to be some geographic variation in the relationship between water temperature and breeding activity. Initiation of breeding in Coyote Creek occurred at temperatures very close to $12^{\circ} \mathrm{C}$ during the 2004-2006 breeding seasons. In addition, peak breeding activity occurred within a narrow range of temperatures $\left(13-16^{\circ} \mathrm{C}\right)$. Data collected during several years of monitoring on different watersheds in California suggested that increasing water and air temperatures likely cue breeding initiation (Kupferberg et al. 2009). Most studies to date recorded breeding initiation temperatures that were close to $12^{\circ} \mathrm{C}$, but initiation temperatures on the Feather River during 2004 and 2005 were at $10^{\circ} \mathrm{C}$ (GANDA 2008). However, peak breeding in that study occurred between 12 and $15^{\circ} \mathrm{C}$. No studies have documented breeding above $20^{\circ} \mathrm{C}$, but Van Wagner (1996) recorded breeding activity up to $20^{\circ} \mathrm{C}$. Foothill yellowlegged frogs may have physiological constraints that do not allow them to breed above $20^{\circ} \mathrm{C}$. Metabolic rates above $20^{\circ} \mathrm{C}$ may prevent them from expending energy toward egg production. In addition, cooler temperatures on the upper reach of Coyote Creek likely explain why it took longer for egg masses to hatch in comparison to the lower reach.

Physical and Habitat Parameters for Egg Masses.-Pools were used almost exclusively during the 2004 and 2005 breeding seasons. There was a partial shift in specific pool use in response to higher flows in 2005. In addition, there was a shift in the upper reach for the utilization of the middle of pools as opposed to pool tail outs, which 
are more subject to scour. Early-breeding frogs tended to make more use of submerged vegetation and roots as attachment substrates, possibly due to lower velocities at the edges of the channel. Coarser substrates provided more of the attachment points during the higher flows during 2005 than in 2004. Fuller and Lind (1991) found that larger substrate material represents the best attachment sites, but submerged vegetation may also be used. In general, frogs deposited eggs in locations closer to shore or in deeper slack water areas in response to increased stream flows and velocities, resulting in a decrease in the amount of preferred breeding habitat available early in the breeding season. However, the availability of shallow, low velocity margin areas is not a breeding cue (Kupferberg et al. 2009).

Management Considerations for Breeding.-Foothill yellow-legged frogs exhibit some plasticity in breeding behavior. However, management strategies that preserve or mimic the linkage of the natural hydrologic cycle and water temperatures have the best chances of allowing populations to persist through time. These strategies should minimize scouring flows and provide preferred temperatures $\left(12-17^{\circ} \mathrm{C}\right)$ during breeding. Hydrologic and temperature regimes on central and South Coast Range watersheds are very different from Cascade, Sierra Nevada and North Coast Range streams. Runoff originates from rainfall rather than snow melt. Runoff varies drastically form year to year on South Coast Range streams, and air and water temperatures are warmer during winter and spring. These factors should be taken into consideration during planning for monitoring breeding and/or when evaluating management actions that alter stream flows. 


\section{Movement/Mark and Recapture}

General Characteristics.-Maximum SVL and weights of adult foothill yellowlegged frogs of both sexes at Coyote Creek were greater than those recorded by Van Wagner (1996) for Clear Creek in the Sierra Nevada foothills, but less than those recorded by GANDA (2008) for the Feather River. Sex ratios recorded on both reaches in 2005 were within the range of those recorded by Van Wagner (1996) during his threeyear study. Adult foothill yellow-legged frogs have been observed utilizing tributaries to breeding streams as resident habitat (PCWA 2008; Bourque 2008). In contrast to the substantial summer dry back on upper Coyote Creek, these Sierra Nevada and North Coast Range streams were perennial. Despite the perennial nature of these breeding streams, some adult frogs elected to use intermittent tributaries as their resident habitat instead. Partially intermittent tributaries are even more crucial for adult frogs as resident habitat on upper Coyote Creek because surface water is scarce and unreliable, particularly during summer and fall, from year to year on the main stem. Some tributaries apparently offer some perennial habitat even during dry years. Most adult female frogs and two-thirds of males in 2005, preferred to use tributaries outside the breeding season. However, two-thirds of adult males observed in 2004 on the lower reach used the main stem after the breeding season. Adult males tend to stay in the breeding areas longer than females, as suggested by the heavily male biased operational daily male/female sex ratios recorded during this and other studies (Van Wagner 1996; GANDA 2007; Wheeler and Welsh 2008). Early dry backs in lower tributary reaches in the Coyote Creek watershed during a dry year such as 2004 may have prevented some 
males from ascending the tributaries following active breeding. The high proportion of adult females residing in summer on Dexter Creek was nearly identical during both years because females bred and moved back up tributaries shortly after breeding, at a time when the tributaries were flowing at and near their confluences with the main stem. Harassment by adult males may influence post-breeding females to move away from breeding areas sooner than they would otherwise. I captured and tagged a large adult post-breeding female near the Dexter Creek confluence area and promptly released her. I observed a male and female about five minutes later locked in amplexus. The female turned out to be the female frog I had just marked. Daily diurnal summer movements were always within a single mesohabitat. Large adult frogs alternated between basking locations and other positions within their home pools to forage or hide.

Movement.- The spatial separation between adult resident and breeding habitat for the majority of adult frogs requires breeding frogs to travel long distances on the lower reach during the pre-breeding/breeding season. Only a small portion of the population (less than ten percent of adult frogs) did not make long distance movements during the pre-breeding/breeding season because their resident habitats were in or near the breeding habitats. Resident main stem females were shorter and weighed less compared to tributary residents. Nearly sixty percent of frogs did not make significant movements during the non-breeding season because the resident habitat was perennial and of relatively high quality. Summer dry backs made it necessary for some frogs to travel significant distances to perennial habitats. Searches for less-crowded and/or higherquality habitats and food resources likely caused adult frogs to make long distance 
movements over dry streambed during rain events to these habitats. The maximum distances recorded during 2005 were much greater than those recorded by Van Wagner (1996), but much shorter than those recorded by Bourque (2008) for Tahama County frogs. The frogs in Van Wagner's study were primarily main stem residents that did not need to travel far for suitable breeding habitat. By contrast, the study area of Bourque (2008) consisted of many intermittent tributaries with preferred resident habitat separated by great distances from the main stem of Red Bank Creek, which provided the breeding habitat for that population.

Movement patterns appear to be adaptive to local physical conditions that determine distribution and connectivity of habitats over the course of these frogs' complex life cycle. All Coyote Creek frogs had the option of making long distance movements to and from breeding sites or for other purposes from December 2004 to early July 2005 because there was connectivity (flowing water) throughout the study area. Long distance movements were restricted once channel drying started. Females moved greater distances during the pre-breeding/breeding season because they tended to move earlier to establish residence in perennial habitats farther away from the breeding areas. Males tended to make smaller incremental movements later in the year as stream flows were decreasing and flow continuity was broken. The highest quality habitats were already occupied by large adult females by the time most males began to move from the breeding areas. Males had to utilize habitats closer to the breeding areas that were largely bypassed by adult females. In contrast, Van Wagner (1996) did not detect a significant difference in the average maximum movements between adult females and males. This is 
likely because there was little or no spatial separation between breeding sites and quality resident habitat throughout the year. The study area of Van Wagner had reliable perennial habitat that possessed all the requirements necessary for foothill yellow-legged frogs to complete their life cycles and no tributaries existed nearby. Coyote Creek adults traveled much farther on average than juveniles during the pre-breeding/breeding season, but variation was high and detected juvenile movements were fewer. Juvenile frogs on Coyote Creek also made significant movements during the pre-breeding/breeding season both upstream and downstream (including ascending tributaries), presumably to seek out higher quality rearing habitat away from predators and to reduce competition for resources. I could not detect an upstream or downstream pattern of movements for all frogs between fall 2004 and subsequent recapture in 2005, because frogs moved in all directions once continuous flow was re-established. This was perhaps a density dependant dispersal behavior, with frogs crowded into scarce perennial habitat during summer and fall 2004, and dispersing to suddenly available habitat throughout the study area once surface flows were re-established during early December, 2005.

Female Movement.-Examining movement histories of individual frogs reinforces conclusions about positive trends relating body size to distance moved and the observed patterns. Large adult females (K99, L02, K37, and L12) clearly traveled farther to resident habitat after breeding (Figures 14 and 16). Smaller adult females (K27, K37, K87 and K98) did not travel as far away as large adult females to resident habitat from the breeding areas. A plot of distance between established residence and nearest breeding sites shows a trend of larger individuals occupying habitats farther away from 
the breeding area (Figure 30). The relationship between food availability and energy expenditure is probably more favorable on the tributaries. One small female (K91) was initially captured over one mile upstream of the confluence on Dexter Creek early during the breeding season. She subsequently moved down to the breeding area, likely bred late during the breeding season, then moved back up Dexter Creek to the closest perennial habitat from the confluence. This frog was a near minimum size for an adult $(43 \mathrm{~mm})$ at initial capture, and grew to $(54 \mathrm{~mm})$ by the end of summer. The longer rainy season and extended higher flows in 2005 perhaps made this possible.

Male Movement.-Similarly, there was a positive relationship between body size and distance moved for adult males. Three of four large adult males (K81, K84, and K95) traveled greater distances than smaller adult males (K86, L18, and K69) (Figures 16 and 18). In addition, their travels away from the breeding areas were made earlier than those of smaller males. This is likely because larger males bred earlier, which allowed them to travel to and to occupy higher-quality perennial habitat that was farther upstream on Dexter Creek. The individual movement histories clearly show males maintained positions close to the breeding areas for longer periods of time than females. All resident tributary males made significant movements away from the main stem, but they did not attempt to occupy habitat farther upstream that large females were able to get to first. Resident main stem males typically moved little in comparison to resident tributary frogs during any season. Distance between established residence and nearest breeding sites showed a trend of larger individuals occupying habitats farther away from the breeding area (Figure 31). July and August 2005 on Dexter Creek was approximately $5^{\circ} \mathrm{C}$ cooler 
than the nearby main stem (Figure 32), which meant that resident frogs on Dexter Creek needed about half the food to maintain body weight as did main stem residents. This suggests that the tributaries may offer physical conditions that favor the attainment of larger body masses and better condition factors. These frogs would have higher fecundity and could make the longer trips to and from the breeding areas.

Radiotracking Efficiency.- - Radiotracking frogs yielded far more accurate activity and microhabitat use data than standard VES or mark and recapture. My activity results were similar to those recorded by Garcia \& Associates 2008. My activity category "under substrate" was largely equivalent to the GANDA activity category "hiding". I would not have been able to detect frogs that were taking position under substrate using standard VES or mark and recapture surveys unless I searched under cobbles and boulders. Biotelemetry enabled me to find many more frogs under water or in the channel but above the surface on substrate or wood than if I used standard VES. Frogs under water may be under leaf litter, turbulence, or in the shadows and consequently very hard to detect employing VES. Frogs utilizing rootwad or boulder microhabitats are especially difficult to detect in comparison to other microhabitat categories. Frogs basking on gravel or cobble bars were far easier to detect using VES, because they were out in the open and were in contrast to the uniform substrate. Frogs were considerably more difficult to see when positioned at the head of pools in comparison to the middle or tail gravel and cobble bars. Pool heads were primarily composed of boulders and cobbles, which break up the silhouette of a frog body. Scanning the heads of pools with binoculars with high quality optics before disturbing the frogs aided in detection, but 
many (or even most) frogs were probably missed. Spending proportionally more time closely inspecting these areas might help mitigate detection deficiencies employing standard VES surveys, but still would miss many frogs.

Biotelemetry would have yielded much more precise and accurate movement data during the pre-breeding/breeding season than standard mark and recapture methods. Biotelemetry would have enabled me to collect data that could be used to calculate movement rates, precisely compare initial movements to the breeding sites with physical parameters such as temperature, and stream flows. Accurate data pertaining to movement and habitat use during late winter and early spring would have been feasible using biotelemetry. Monitoring movements from resident habitat to the breeding sites would have been possible during a very wet late winter and early spring such as 2005 .

Growth.-The size and growth patterns observed in this study of coastal frogs seem to agree generally with those observed for a Sierra Nevada foothill population studied by Van Wagner (1996). Females exhibited greater growth rates and reached much larger sizes than males. However, Coyote Creek young of the year growth showed less variability than that observed by Van Wagner (1996). Most of the rearing habitats for foothill yellow-legged frogs on Coyote Creek had canopy coverage of less than 60 percent. Many portions of Van Wagner's study area had canopy coverage of greater than 90 percent. As a consequence of shading and reduced primary productivity and insect availability as food, one would expect longer and more variable development times for tadpoles to reach metamorphosis. In contrast, Coyote Creek frogs exhibited higher growth rates, and they reached maturity more rapidly than frogs on the Feather River 
(Figure 33). The Feather River is a higher elevation Sierra Nevada stream that has snowdominated runoff and cooler air temperatures during spring, which is typical of Sierra Nevada streams.

Precipitation varied between 2004, a dry year with a short breeding season, and 2005 a very wet year with a long breeding season. All tadpoles transformed prior to July 1 within the Coyote Creek study area during both 2004 and 2005. This means that the latest eggs deposited during 2005 were fully transformed within 45 days. Young of the year frogs on Coyote Creek had much more time to grow after metamorphosis before the onset of cooler late fall temperatures than later breeding populations in the Sierra Nevada and North Coast Ranges. Foothill yellow-legged frogs typically transform during late summer and early fall in populations farther north and at higher elevations. Foothill yellow-legged frogs in some years can reach reproductive size as yearlings on upper Coyote Creek. Egg mass size, timing of breeding, and smaller observed sizes of frogs at the breeding area late during the 2005 breeding season suggests yearling frogs contributed to breeding.

Low recruitment to adulthood, due to very high spring flows and resulting egg mass scour and/or tadpole mortality should be detectable two years later. I did not collect data on young of the year during 2005, but I observed no foothill yellow-legged frog tadpoles after July 1. Growth was likely to be similar to 2004, despite the significant differences in the magnitudes of stream flow between 2004 and 2005. Water temperatures exceeded $18^{\circ} \mathrm{C}$ by mid-May during 2005 , and relatively warm water temperatures and high food availability earlier in the year for rearing tadpoles and transformed young of the year 
frogs likely explain the observed growth differences between this population and the more extensively studied populations of the Sierra Nevada and North Coast Ranges (Kupferberg 2008). Foothill yellow-legged frogs in watersheds farther south, with breeding populations that experience relatively warm water temperatures and high food availability earlier in the year, likely exhibit similar growth characteristics as those in Coyote Creek. For example, I observed hundreds of juvenile frogs on approximately a 1 $\mathrm{km}$ stretch of Clear Creek near the confluence with the San Benito River in San Benito County during September 2005 that were clearly close to $40 \mathrm{~mm} \mathrm{SVL}$. Clear Creek is perennial but un-shaded and very warm (up to $26^{\circ} \mathrm{C}$ ) in spring through fall. Food availability is likely to be relatively high for a relatively longer period of the year in this watershed.

\section{Mesohabitat Preference}

In general, females established themselves in resident habitat sooner after breeding than males. As a consequence, they chose the best quality habitat available (deeper, more complex pools). Competitive interactions between adult females and males likely favored larger females and may have allowed for females to maintain residence within the highest quality habitats after the arrival of males from the breeding sites. This may explain why males tended to use mesohabitats that possessed less complex escape cover. This highlights the importance of habitat heterogeneity to maintain populations. Overall, the use by many larger frogs of the tributary over the main stem may be due in part to energetic factors. Daily mean air temperatures were significantly lower on Dexter Creek than on the lower reach on the main stem (Figure 32). Future studies that investigate 
microhabitat use and preference may give a better understanding of mesohabitat use and preference. For example, investigating when and where sunlight hits particular parts of mesohabitats, escape cover, substrate, food availability, and their utilization by frogs would be useful. Biotelemetry would be the most effective mode of investigation of specific microhabitat use and preferences as well as frog activity patterns.

\section{Predators}

Moyle (1973) suggested predation would take a higher toll on fragmented foothill yellow-legged frog populations that remain on tributaries of Sierra Nevada watersheds. In many of these tributaries reside non-native, highly predacious and aggressive green sunfish. By contrast, tributaries within the upper Coyote Creek study area had no introduced predators and relatively few native diurnal predators in comparison with the main stem of Coyote Creek. There were far fewer snakes and no predatory birds observed on Dexter Creek. In addition, the only potential ranid predators observed were California red-legged frogs, which consisted mainly of young of the year frogs (i.e., current years reproductive output) that presumably migrated downstream from breeding sites (primarily livestock ponds) farther upstream on the watershed. The few adult California red-legged frogs that resided within the tributaries may not pose a substantial threat to adult mature adult foothill yellow-legged frogs due to the largely nocturnal behavior of California red-legged frogs. In addition, mature adult female foothill yellowlegged frogs may have been too large for most California red-legged frogs to ingest. I observed a large female adult foothill yellow-legged frog and a large California redlegged frog basking less than $0.6 \mathrm{~m}$ away from each other on several occasions. In short, 
the lack of diurnal predators on the tributaries within the study area apparently contributes to their value as a summer habitat for adult foothill yellow-legged frogs.

Observed potential diurnal predators on the main stem of Coyote Creek outnumbered those observed on Dexter Creek by greater than an order of magnitude. The principal non-native predators observed on the main stem were bullfrogs. A small number of Centrarchids (largemouth bass, bluegill, and green sunfish) were observed during spring 2005. The majority of these fish were juveniles less than $100 \mathrm{~mm}$ long that presented little predation threat, except possibly to tadpoles. These were likely washed down with high flows from local livestock ponds. The ephemeral nature of most of the upper Coyote Creek watershed does not favor the establishment of largemouth bass or bluegill populations. Their limited numbers and unfavorable physical habitat conditions on the upper Coyote Creek watershed greatly diminish their impact as predators. Some adult bullfrogs seemed to be seasonal spring migrants from Coyote Reservoir, as they were observed with greater frequency during spring 2004 and 2005 closer to the reservoir. However, adult bullfrogs were seldom seen after Coyote Creek dried back in early summer and as tadpoles transformed and adults migrated back to their resident habitats. A small number of bullfrog tadpoles were washed down from livestock ponds from the heavy rains and high flows of winter-spring 2005. Few of these bullfrog tadpoles transformed into frogs. Most of the habitats in which they were trapped dried up before they could transform. In addition, perennial habitats had adult California red-legged frogs that may have taken a heavy toll on tadpoles and juveniles. No foothill yellowlegged frogs were found in any of the several bullfrog stomachs I checked on the lower 
reach over the course of the study. However, adult bullfrogs often had adult breeding Pacific chorus frogs, California roach (Lavinia symmetricus) and juvenile Sacramento suckers (Catostomus occidentalis) in their stomachs. On one occasion, I found a hatchling western pond turtle (Emys marmotorata) in an adult bullfrog stomach on the lower reach during May 2005.

The small numbers of bullfrogs and Centrarchid fish, to which foothill yellow-legged frogs are not adapted, potentially impact foothill yellow-legged frogs, even though I could not detect an effect during my study. These potential impacts may be more substantial when tadpole and adult recruitment is low due to severe late season storms or prolonged droughts

Santa Cruz aquatic garter snakes were by far the most detectable native predator. They were distributed throughout the main stem and active at all seasons that foothill yellow-legged frogs were. Many previous studies have recorded aquatic garters as the most commonly encountered predator where foothill yellow-legged frogs reside (Nussbaum 1983; Jennings and Hayes 1988; Lind and Welsh 1994). Common mergansers accounted for one-fifth of the predator sightings. However, their relative impact as predators was likely quite high in habitats they hunted. I found that tadpoles had been decimated in specific amphibian breeding habitats, mostly in the middle reach, by a female common merganser and her six chicks. Surveys conducted on habitats prior to their detection yielded observations of thousands of western toad, Pacific chorus frog and foothill yellow-legged frog tadpoles. Tadpole numbers were reduced to near zero after these birds foraged these habitats for a week or so. Their metabolic needs as 
endotherms, greatly increase the amount of potential prey consumed relative to the much more common Santa Cruz garter snake.

\section{Illegal Marijuana Cultivation}

Illegal marijuana cultivation is a current threat to the foothill yellow-legged frog population on upper Coyote Creek, and likely a threat to all aquatic species, including western pond turtles and California red-legged frogs, within the watershed. There were marijuana plantations on four tributaries that flow into the main stem within the study area. I observed foothill yellow-legged frogs on three of these tributaries during the study. The marijuana cultivators constructed small impoundments and lined them with impervious sheets of plastic to minimize water flowing past the impoundments, and used irrigation pipes to transport water directly to the plants. The cultivators often poured chemical fertilizers directly into the water of the impoundments. The cultivators denuded the terrestrial habitat adjacent to the streams and terraced the slopes. I observed containers of herbicides and pesticides which would presumably be used to protect the marijuana plants from competitors and pests. All of the activities associated with marijuana cultivation on these headwater streams have a strong potential to harm either the physical habitat or the frogs directly.

The tributary below Sheep Ridge had both frogs and marijuana gardens on it during 2004 and 2005. I consistently encountered 6 to 13 adult frogs during the VES surveys conducted during the summer of 2004. There was one impoundment and two gardens that year. The operations expanded during 2005 to three impoundments and seven gardens with about 6,500 plants. The maximum number of frogs I observed on this 
tributary during 2005 VES survey was four; the frogs had less water available to them in 2005, even though 2005 was a wetter year. However, more adult males were able to move into the adjacent tributary, Dexter Creek, during 2005. Marijuana cultivation on the Sheep Ridge tributary likely caused a decline in observed frogs. Dexter Creek did not have marijuana gardens during the study, but other tributaries utilized for illegal marijuana gardens on this watershed are likely to exhibit the same effect on foothill yellow-legged frog abundance. The number of breeding female frogs (based upon egg masses) in the lower reach was only 6 in 2010 (J. Smith, personal communication). This is compared with 41 in 2004 and 59 in 2005, with the drastic decline possibly due to effects of the 2007 drought and/or to expansion of marijuana operations to Dexter Creek watershed during 2006-2009. However, no evidence of marijuana cultivation in the tributary was seen in 2010 . The upper site had 13 egg masses in two pools that were checked versus 31 and 44 in eight pools checked in 2004 and 2005. It does not appear there has been a population collapse on the upper site as has happened for the lower site.

There has been an explosive increase in illegal marijuana growing in California in the past fifteen years. Drug trafficking organizations from Mexico are primarily responsible for this trend. They utilize tributaries and headwaters which are occupied by remnant populations of sensitive aquatic species such as foothill yellow-legged frogs or those with the potential to support these animals. Small, isolated foothill yellow-legged frog populations are likely to be susceptible to these illegal marijuana gardens. 


\section{Management Implications}

The results of this study may aid resource managers within the southern part of the distribution of the foothill yellow-legged frog. Many watersheds in the Diablo Range and farther south have a mixture of perennial, intermittent, and ephemeral reaches and have not been studied. Almost all of these streams lack snow runoff, and instead receive flashy runoff from rain. These conditions are in contrast to the streams of the Sierra Nevada and North Coast Range, which have been studied relatively extensively. As a result, the ecology of foothill yellow-legged frogs in the southern part of their range differs in breeding, movement, habitat use/ preference, and growth. This study was conducted during one moderate and two relatively wet years in central California. Studies should be conducted in this region during dry years to determine population responses to less water, shorter duration of it's availability, and pattern of population recovery after drought. Water availability is a limiting factor on upper Coyote Creek from at least mid-summer to late fall, even during wet years. All water diversions, whether legal or illegal, are likely to be the most serious threat to the continued persistence of this species on Coyote Creek and other similar watersheds. In addition, construction of impoundments on these streams is sure to have impacts on breeding success, encroachment by non-native predators, and habitat degradation as has been demonstrated on studied watersheds in the central and northern parts of the foothill yellow-legged frogs' range. 


\section{REFERENCES}

Ashton, D.T., A. J. Lind, and K. E. Schlick. 1998. Foothill yellow-legged frog (Rana boylii) natural history. USDA Forest Service, Pacific Southwest Service station, Arcata, California. 18 pp.

Ashton, D.T., and R. J. Nakomoto. 2007. Rana boylii predation. Herpetological Review. 38 (4): 442.

Blaustein, A. R., P. D. Hoffman, D. G. Hokit, J. M. Keisecker, S. C. Walls, and J. B. Hays. 1994a. UV repair and resistance to solar uv-b in amphibian eggs: A link to population declines? Proceedings of the National Academy of Sciences 91(5):1791-1795.

Blaustein, A. R., D. G. Hokit, R. K. O’Hara, and R. A. Holt. 1994b. Pathogenic fungus contributes to amphibian losses in the Pacific Northwest. Biological Conservation 67(3):251-254.

Bourque, R. M. 2008. Spatial ecology of an inland population of the foothill yellowlegged frog (Rana boylii) in Tahama County, California. Masters Thesis. Humboldt State University. Arcata, California.

Brown, L. M. 1982. Age, growth, feeding and behavior of Sacramento squawfish (Ptychocheilus grandis) in Bear Creek, Colusa County, California. Master's Thesis. University of California, Davis, California.

Bury, R. B., and P. S. Corn. 1991. Sampling methods for amphibians in streams in the Pacific Northwest. USDA Forest Service, Pacific Northwest Research Station, Portland, Oregon. Gen. Tech. Rep. PNWGTR275.

Cattenazi, A., and S. J. Kupferberg. 2009. Growth, development, and susceptibility to parasites of larval foothill yellow-legged frogs (Rana boylii) in relation to water temperature: implications for management of California's hydroelectric dams. Presentation to Declining Amphibian Populations Task Force, California and Nevada Working Group.

Chelgren, N. D. 2003. Effects of body size on the survival and timing of emigration of newly metamorphosed northern red-legged frogs. Masters Thesis. Oregon State University. Corvallis, Oregon.

Colborn, T., and C. Clement, eds. 1992. Chemically-induced alterations in sexual and functional development. Advances in Environmental Toxicology. Vol. XXI. Princeton Scientific Publ. Co., Inc. 
Davidson, C., Bradley, H., and M. R. Jennings. 2002. Spatial tests of the pesticide drift, habitat destruction, uv-b, and climate-change hypotheses for California amphibian declines. Conservation Biology: 16(6):1588-1601.

Dever, J. A. 2007. Fine-Scale Genetic Structure in the Threatened foothill yellowlegged frog (Rana boylii). Journal of Herpetology: 41(1)168-173.

Drennan, J., R. E. Jackman, K. R. Marlow, K. D. Wiseman, J. S. Minton and J. J. Kim. 2005. Crayfish predation on foothill yellow-legged frog (Rana boylii) egg masses in the northern Sierra Nevada. Garcia and Associates, San Francisco, CA. Presentation to Declining Amphibian Populations Task Force, California and Nevada Working Group.

Drennan, J., R. E Jackman, K. R. Marlow, and K. D. Wiseman. 2006. Climatic and water flow triggers associated with breeding and movement in a foothill yellowlegged frog (Rana boylii) population on the North Fork Feather River, California. Garcia and Associates, San Francisco, CA. Presentation to Declining Amphibian Populations Task Force, California and Nevada Working Group.

Drost, A. D., and G. M. Fellers. 1996. Collapse of a regional frog fauna in the Yosemite area of the California Sierra Nevada. Conservation Biology 10:414-425.

Duellman, W. E., and L. Trueb. 1986. Biology of the Amphibians. McGraw-Hill Publishing Company. New York, NY.

Ellis, M. J., and J. D. Cook, Spring River Ecological Services. 2004. Pulsed flows effects on foothill yellow-legged frog egg masses, filamentous green algae, and fish stranding in the Pit River. Presentation given at the annual meeting of The Wildlife Society, Western Section

Evendon, F. G., Jr. 1948. Food habits of Triturus granulosa in western Oregon. Copia (3):219-220.

Fellers, G. M. 2001. Recent observations of Chytridiomycosis among amphibians in California. Presentation to Declining Amphibian Populations Task Force, California and Nevada Working Group.

Fellers, G. M., P. M. Kleeman, D. W. Sparling, and L. L. McConnell. 2007. Possible factors in the decline of California amphibians: contaminants and disease.

Presentation to Declining Amphibian Populations Task Force, California and Nevada Working Group.

Fellers, G. M., and P. M. Kleeman. 2009. The role of pesticides in the decline of amphibians in the Sierra Nevada, California. Presentation to Declining Amphibian Populations Task Force, California and Nevada Working Group. 
Fitch, H. S. 1938. Rana Boylii in Oregon. Copeia 2:148.

Fuller, D. D., and A. J. Lind. 1991. Implications of fish habitat improvement structures for other stream vertebrates. Pages 96-104 in H.M Kerner (Editor) and R.R Harris and D.C. Erman (Technical Coordinators). Proceedings of the Symposium on Biodiversity of Northwestern California, October 28-30, 1991. Wildlands Resource Center, University of California, Technical Report (29).

Garcia and Associates (GANDA). 2002. Results of 2001 surveys for northern leopard frog (Rana pipiens), cascades frog (Rana cascadae), foothill yellow-legged frog (Rana boylii), mountain yellow-legged frog, (Rana muscosa), California redlegged frog (Rana aurora draytonii) and western pond turtles (Clemmys marmorata) within the upper North Fork Feather River Project area. Prepared for Pacific Gas and Electric Company. Poe Project FERC No. 2105 draft application for new license.

Garcia and Associates (GANDA). 2008. Identifying microclimatic and water flow triggers associated with breeding activities of a foothill yellow-legged frog (Rana boylii) population on the North Fork Feather River, California. California Energy Commission, PIER Energy Related Environmental Research Program. CEC-5002007-041.

Goldberg, C. S., Goode, M. J., Schwalbe, C. R., and J. L. Jarchow. 2002. External and implanted methods of radio transmitter attachment to a terrestrial anuran. Herpetological Review, 33(3):191-194.

Hayes, M. P., and M. R. Jennings. 1986. Decline of ranid frog species in western North America: are bullfrogs (Rana catesbeiana) responsible? Journal of Herpetology 20:490-509.

Hayes M. P., and M. R. Jennings. 1988. Habitat correlates and distribution of the California red-legged frog (Rana aurora draytonii) and foothill yellow-legged frog (Rana boylii): implications for management. Pages 144-158 in R.C Scaro, K.E. Severson, D.R Patton, technical coordinators. Management of amphibians, reptiles and small mammals in North America. USDA Forest Service, Rocky Mountain Forest and Range Experiment Station, Gen. Technical Report RM-166, Fort Collins, CO, USA.

Hayes, T., K. Haston, M. Tsui, A. Hoaung, C. Haeffle, and A. Vonk. 2002. Atrizine induced hermaphroditism at $0.1 \mathrm{pbb}$ in American frogs (Rana pipiens): laboratory and field evidence. Environmental Health Perspectives, October 23. 
Hawkins, C. P., J. F. Kershner, P. A. Bisson, M. D. Bryant, L. M. Decker, S. V Gregory, D. A. McCullough, C. K. Overton, G. H. Reeves, R. J. Steedman, and M. K Young. 1993. A hierarchival approach to classifying stream habitat features. Fisheries 18(6):3-12.

Hothem, R. L., A. M. Mekstroth, K. E. Wegner, M. R. Jennings, and J. J. Crayon. 2009. Diets of three anurans from Cache Creek watershed, California, USA. Journal of Herpetology 43(2):275-285

Ibis Environmental, Inc. 2002. Results of 2001 surveys for foothill yellow-legged frog (Rana boylii) in the Mokelumne River Project area. Prepared for Pacific Gas and Electric Company.

Jackman, R. E., J. E. Drennan, K. R. Marlow, and K. D. Wiseman, Garcia and Associates. 2004. Some effects of spring and summer pulsed flows on riverbreeding foothill yellow-legged frogs (Rana boylii) along the North Fork Feather River. Presentation given at the annual meeting of The Wildlife Society, Western Section.

Jennings, M. R., and M. P. Hayes. 1988. Natural history and decline of native ranids in California. Pages 61-72 in H. F. De Lisle, P. R. Brown, B. Kaufman, and B. M. McGurty (editors). Proceedings of the Conference on California Herpetology. Southwestern Herpetologists Society.

Jennings, M. R., and M. P. Hayes. 1994. Amphibian and reptile species of concern in California. Final report submitted to the California Department of Fish and Game Inland Fisheries Division. 1701 Nimbus Rd. Rancho Cordova, California.

Johnson, P., and R. Saulino. 2007. Investigating chytrid fungus in and around Pinnacles National Monument. National Park Service, Pinnacles National Monument. Presentation to Declining Amphibian Populations Task Force, California and Nevada Working Group.

Kupferberg, S. J. 1996a. The ecology of native tadpoles (Rana boylii and Hyla regilla) and the impacts of invading bullfrogs (Rana catesbeiana) in a northern California river. Dissertation, Department of Integrative Biology, University of California, Berkeley.

Kupferberg, S. J. 1996b. Hydrologic and geomorphic factors affecting conservation of a river breeding frog (Rana boylii). Ecological Applications 6(4):1322-1344.

Kupferberg, S. J., A. J. Lind., J. Mount, and S. M. Yarnell. 2009. Pulsed flow effects on the foothill yellow-legged frog (Rana boylii): integration of empirical, experimental and hydrodynamic modeling approaches. Final Report. California Energy Commission. Publication number TBD. 
Lind, A.J., H. H. Welsh Jr., and R. A. Wilson. 1996. The effects of a dam on breeding habitat and egg survival of the foothill yellow-legged frog (Rana boylii) in northwestern California. Herpetological Review. 27(2):62-67.

Lind, A. J. 2005. Reintroduction of a declining amphibian: determining an ecologically feasible approach for foothill yellow-legged frog (Rana boylii). Unpublished PhD. Dissertation. University of California, Davis.

Lind, A. J., S. M. Yarnell, and S. J. Kupferberg. 2008. Development of habitat suitability criteria for the foothill yellow-legged frog (Rana boylii) in the Northern Sierra Nevada, and Coast Ranges of California. Presentation to Declining Amphibian Populations Task Force, California and Nevada Working Group.

Lind, A. J., S. J. Kupferberg, and W. J. Palen. 2009. Assessing effects of altered hydrologic regimes on Rana boylii using a population projection model. Presentation to Declining Amphibian Populations Task Force, California and Nevada Working Group.

Lowe, J. 2007. Chytrid distribution in foothill yellow-legged frogs and Pacific tree frogs in the Diablo Mountains and San Joaquin Valley Foothills of central coastal California. Bureau of Land Management, Hollister, CA. Presentation to Declining Amphibian Populations Task Force, California and Nevada Working Group.

MacTeague, L., and P.T. Northern. 1993. Underwater vocalizations by the foothill yellow-legged frog (Rana boylii). Transactions of the Western Section of the Wildlife Society 29:1-7.

Mathews, K. R., and K. L. Pope. 1999. A telemetric study of the movement patterns and habitat use of Rana Muscosa, the mountain yellow-legged frog, in a high elevation basin in Kings Canon National Park. Journal of Herpetology 33(4): 615-624.

Morey, S. 2000. Foothill yellow-legged frog Rana boylii. California Wildlife Habitat Relationships System, California Department of Fish and Game, California Interagency Wildlife Task Group. Available on the internet at: http://www.dfg.ca.gov/whdab/cwhr/A043.html.

Moyle, P. B. 1973. Effects of introduced bullfrogs, Rana catesbeiana, on native frogs of the San Joaquin Valley, California. Copeia 1973 (1):18-22.

Moyle, P. B. and J. J. Cech Jr. 1996. Fishes; An Introduction to Ichthyology, $3^{\text {rd }}$ Edition. Prentice Hall. New Jersey. 
Nussbaum, R. A., E. D. Brodie, and R. M. Storm. 1983. Amphibians \& reptiles of the Pacific Northwest. University Press of Idaho.

PacifiCorp. 2002. Klamath River hydroelectric project foothill yellow-legged frog surveys draft survey protocol.

Peek, R., and S. Khandwala. 2006. Rana boylii plasticity and management under damcontrolled flows in the northern west-slope Sierra Nevada. Stillwater Sciences, Berkeley, CA. Presentation to Declining Amphibian Populations Task Force, California and Nevada Working Group.

Placer County Water Agency. 2008. AQ 12-special-status amphibian and aquatic reptile technical study report-2007. Final report. Placer County Water Agency Middle Fork American River Project (FERC No. 2079).

Poch, J. A., and J. A. Dever. 2008. Determining Genetic Structure of the foothill yellow-legged frog (Rana boylii) using RAPD markers. University of San Francisco. A poster presentation at the Evolution Meeting 2008.

Ritson, P. I., and M. P. Hayes. 2000. Late season activity and overwintering in the northern red-legged frog (Rana aurora aurora). Final report to US Fish and Wildlife Service.

Rosgen, D. L. 1996. Applied River Morphology. Wildland Hydrology. Pagosa Springs, Colorado.

Seltenrich, C. P., and A. C. Pool. 2002. A standardized approach for habitat assessments and visual encounter surveys for the foothill yellow-legged frog (Rana boylii). Pacific Gas and Electric Company.

Seltenrich, C. P., and A. C. Pool. 2006. Habitat variability observed at foothill yellowlegged frog (Rana boylii) breeding locations in several large river drainages along the west slope of the Sierra Nevada: implications for developing survey strategies. ECORP Consulting, Inc. American Fisheries Society CaliforniaNevada Chapter Annual Meeting.

Sparling, D. W., and G. Fellers. 2007. Comparative toxicity of chlorpyrifos, diazinon, malathion and their oxon derivatives to larval Rana boylii. Environmental Pollution 147:535-539.

Stebbins, R. C. 2003. A Field Guide to Western Reptiles and Amphibians, 3rd Edition, Revised. Houghton Mifflin Company, Boston.

Storer, T. I. 1925. A synopsis of the amphibians of California. University of California Publications in Zoology 27:1-342. 
Van Wagner, T. J. 1996. Selected life history and ecological aspects of a population foothill yellow-legged frogs (Rana boylii) from Clear Creek, Nevada County, California. Masters Thesis, Department of Biological Sciences, California State University, Chico.

Vollmar, J. E. (ed.). 2002. Wildlife and rare plant ecology of eastern Merced County's vernal pool grasslands. Vollmar Consulting, Berkeley, CA.

Vredenburg, V. T., R. Knapp, T. Tate, and C. Briggs. 2009. Rapid spread of Batrachochytrium dendrobatidis causes Chytridiomycosis outbreaks and extinctions in yellow-legged frogs of the Sierra Nevada. Presentation to Declining Amphibian Populations Task Force, California and Nevada Working Group

Watson, W. W., McAllister, K. R., and D. J. Pierce. 2003. Home ranges, movements, and habitat selection of Oregon spotted frogs (Rana pretiosa). Journal of Herpetology 37(2):292-300.

Wheeler, C. A., and H. H. Welsh, Jr. 2008. Mating strategy and breeding patterns of the foothill yellow-legged frog (Rana boylii). Herpetological Conservation and Biology 3(2):128-142.

Yarnell, S. M. 2000. The influence of sediment supply and transport capacity on foothill yellow-legged frog habitat, South Yuba River, California. Masters Thesis. University of California, Davis.

Zeiner, D. C., W. F. Laudenslayer, Jr., and K. E. Mayer, eds. 1988. California's wildlife, volume 1, amphibians and reptiles. California Department of Fish and Game.

Zweifel, R. G. 1955. Ecology, distribution and systematics of frogs in the Rana boylii group. University of California Publications in Zoology 54:207-292.

\section{Personal Communications}

Drennan, J. 2008. Personal communication.

Kupferberg, S. J. 2008. Personal communication

Smith, J. J. 2010. Personal communication 
FIGURES 


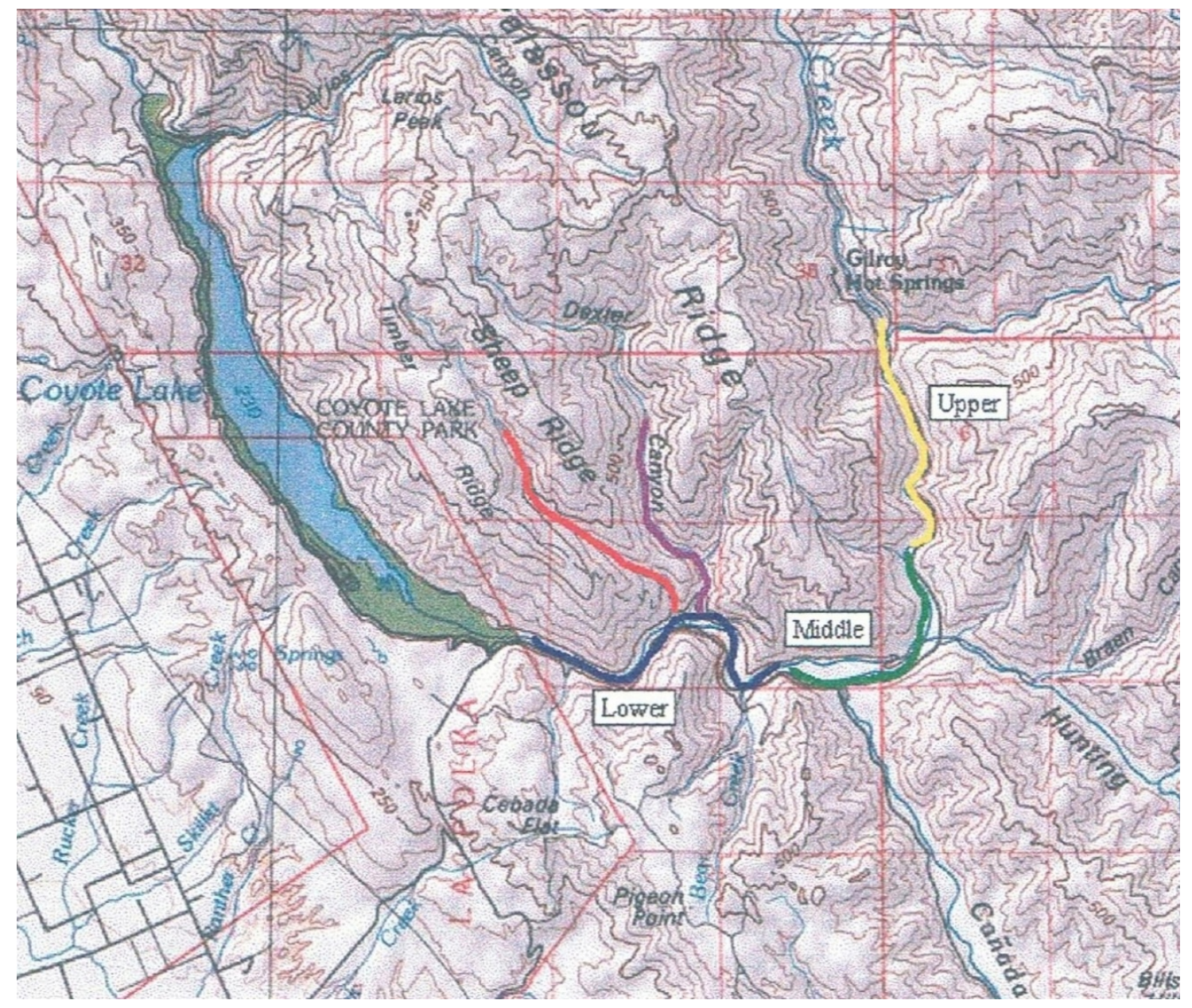

FIGURE 1.-Map of study area. Data collection occurred on upper Coyote Creek between the high water mark of the reservoir and Gilroy Hot Springs. 


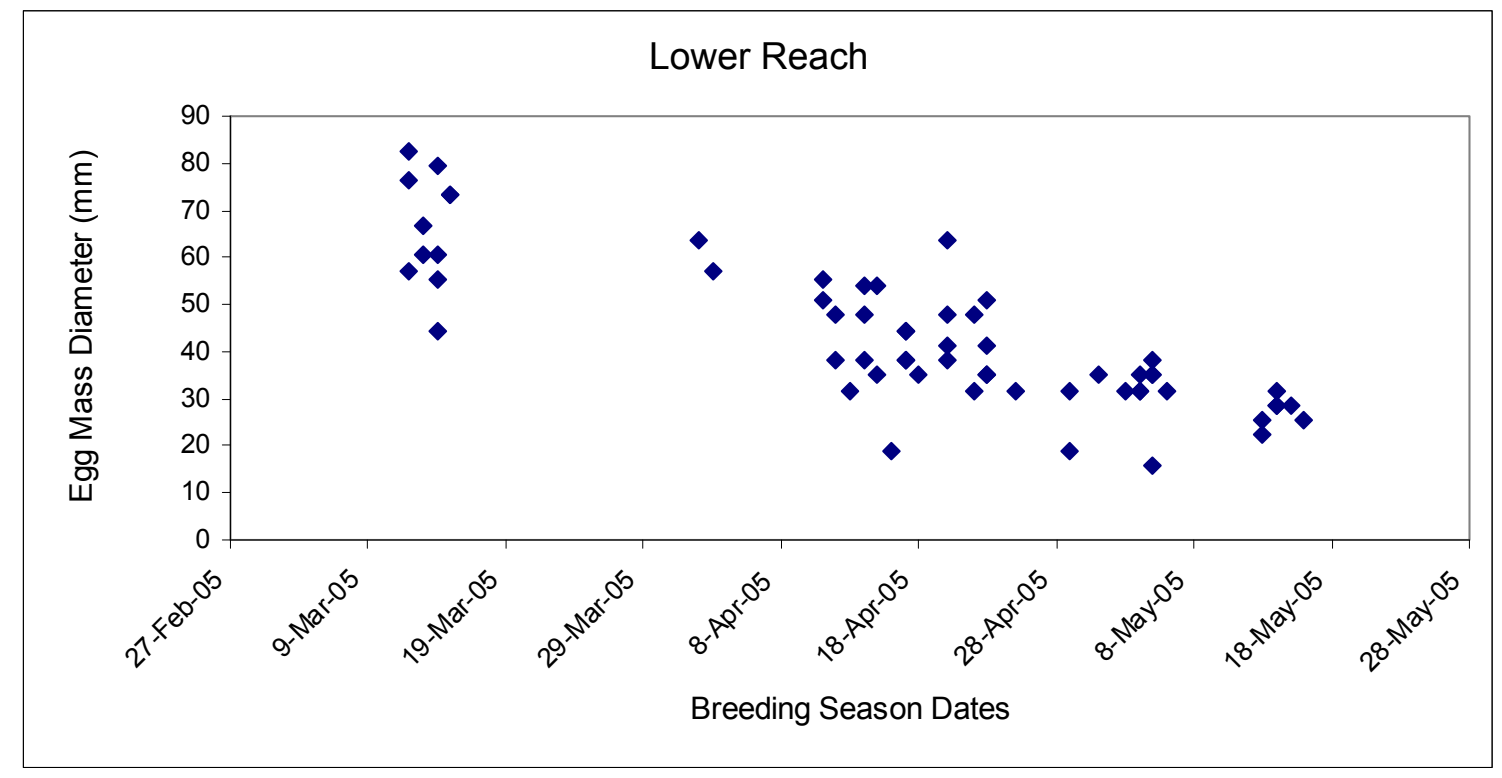

FIGURE 2.-Egg mass diameter through the breeding season on the lower reach of Coyote Creek in 2005.

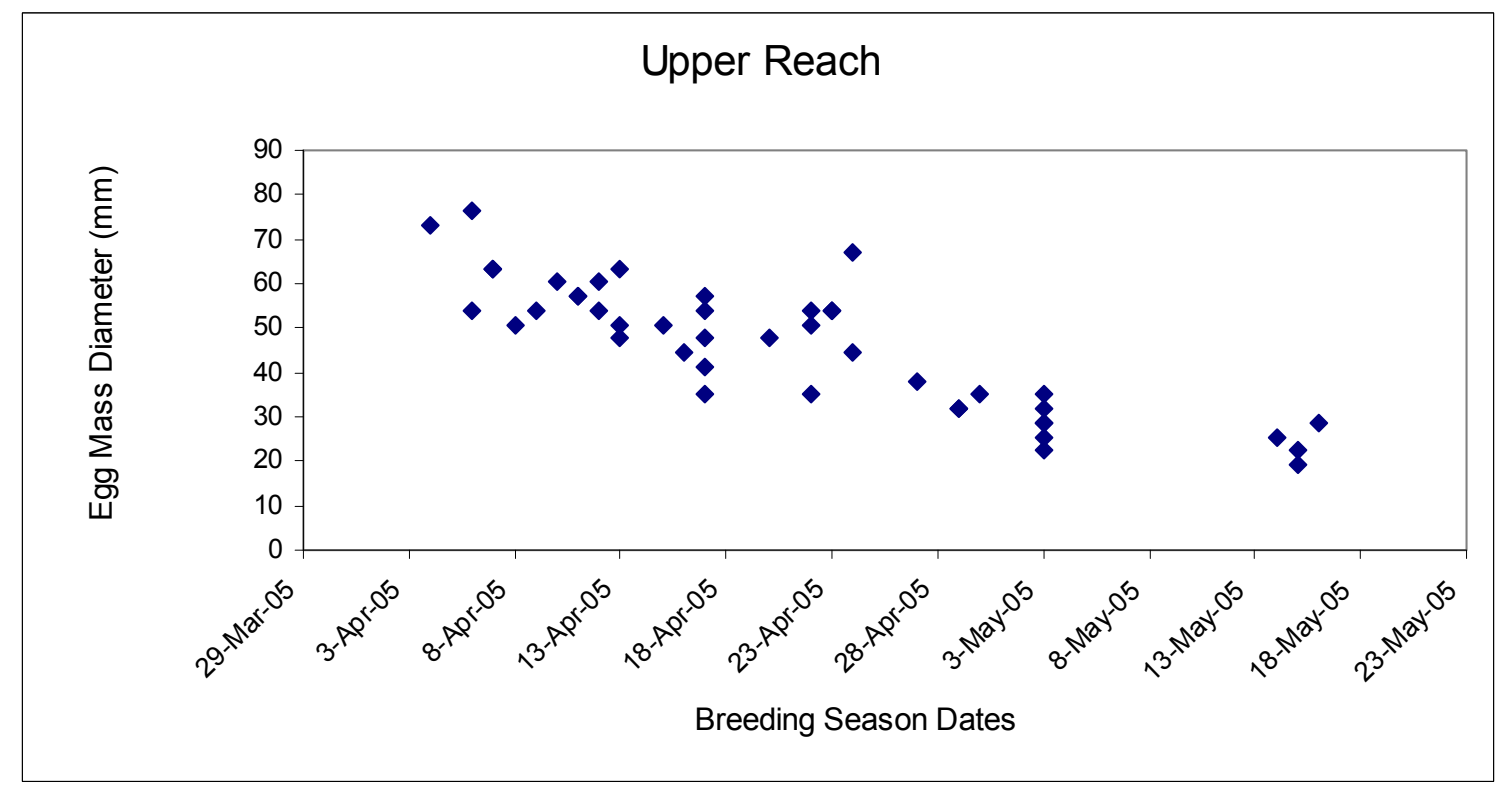

FIGURE 3.-Egg mass diameter through the breeding season on the upper reach of Coyote Creek in 2005. 


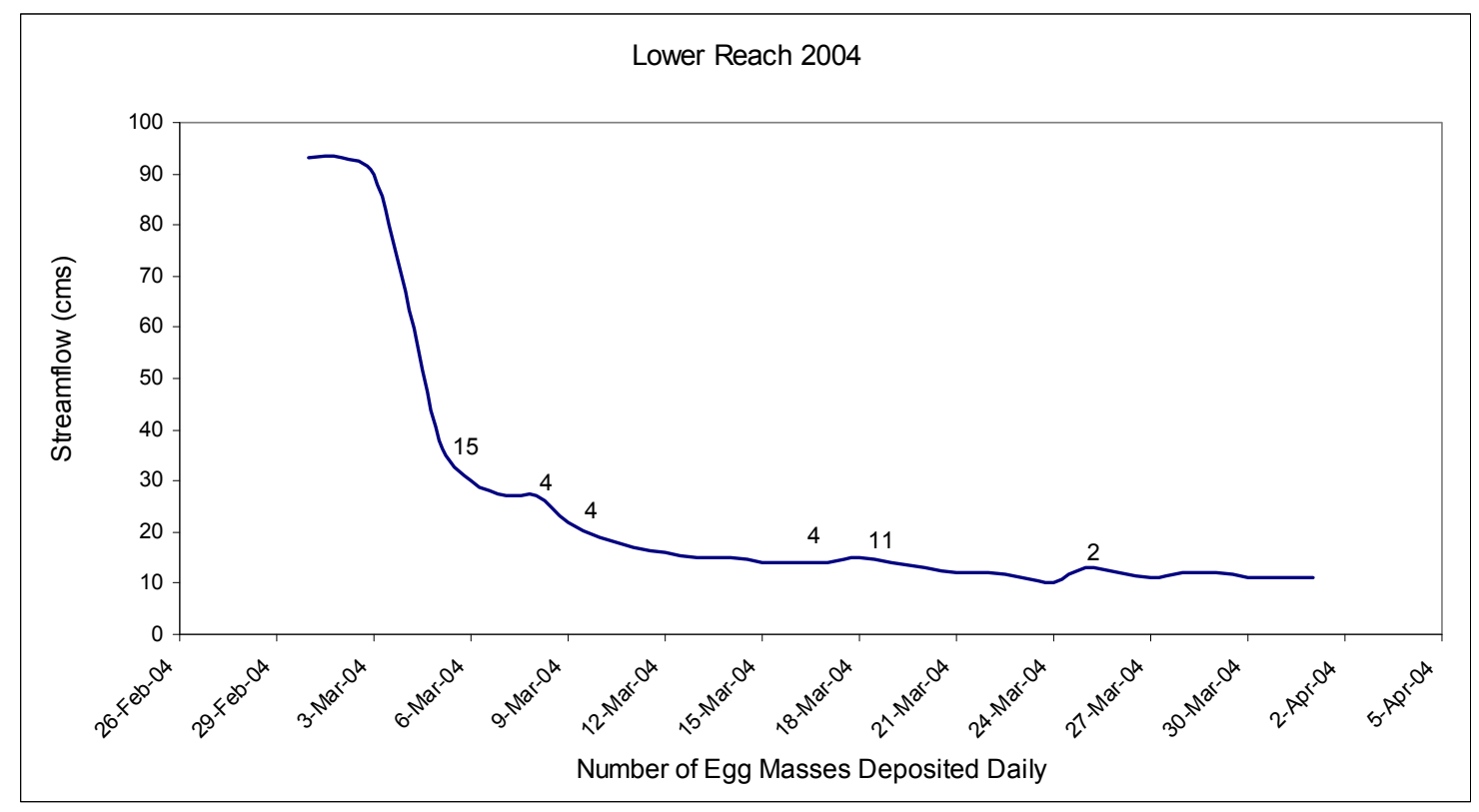

FIGURE 4.-Stream flow in association with daily oviposition on the lower reach of Coyote Creek in 2004. Numbers indicate the number of new egg masses observed during surveys.

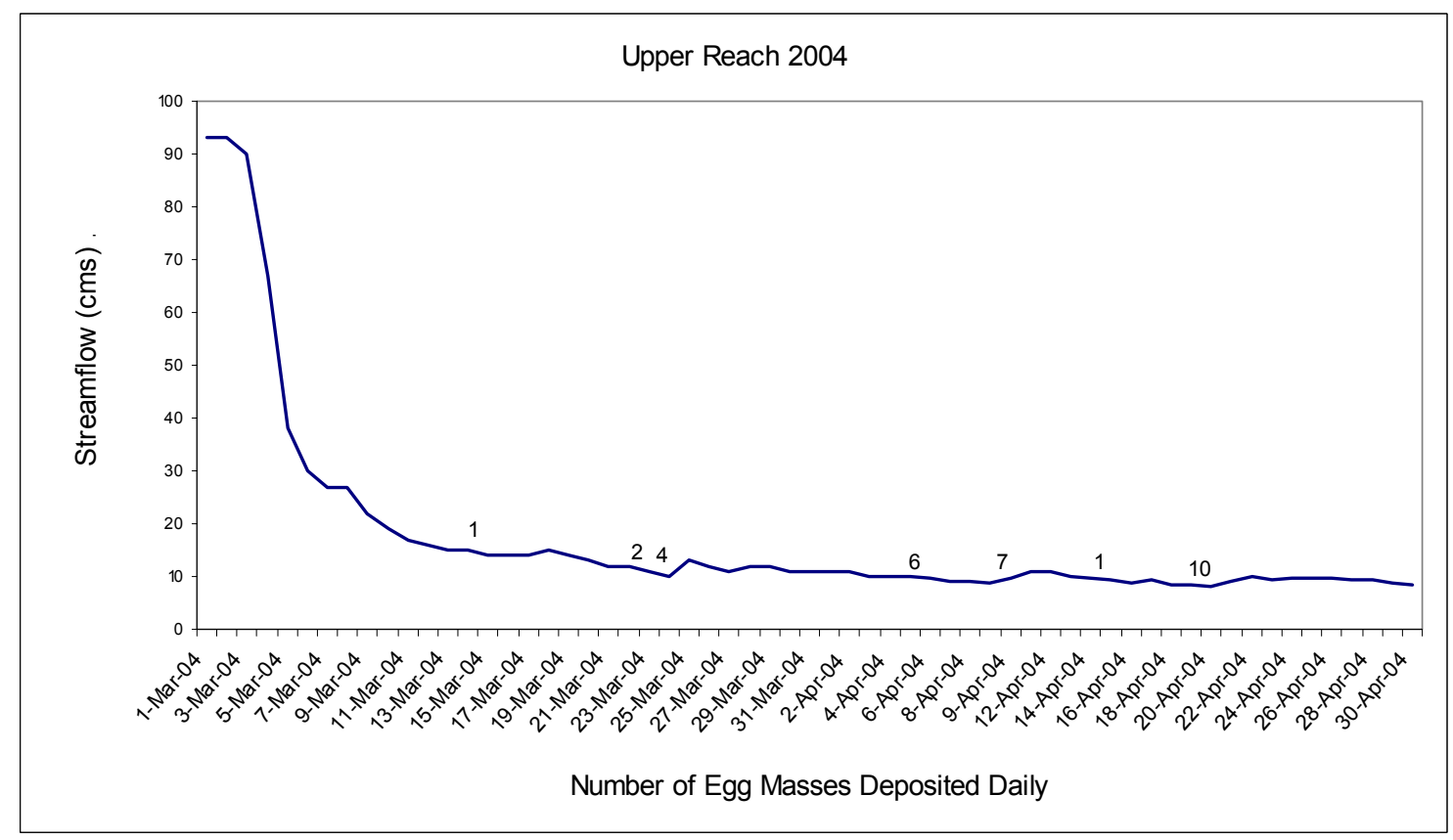

FIGURE 5.-Stream flow in association with daily oviposition on the upper reach of Coyote Creek in 2004. Numbers indicate the number of new egg masses observed during surveys. 


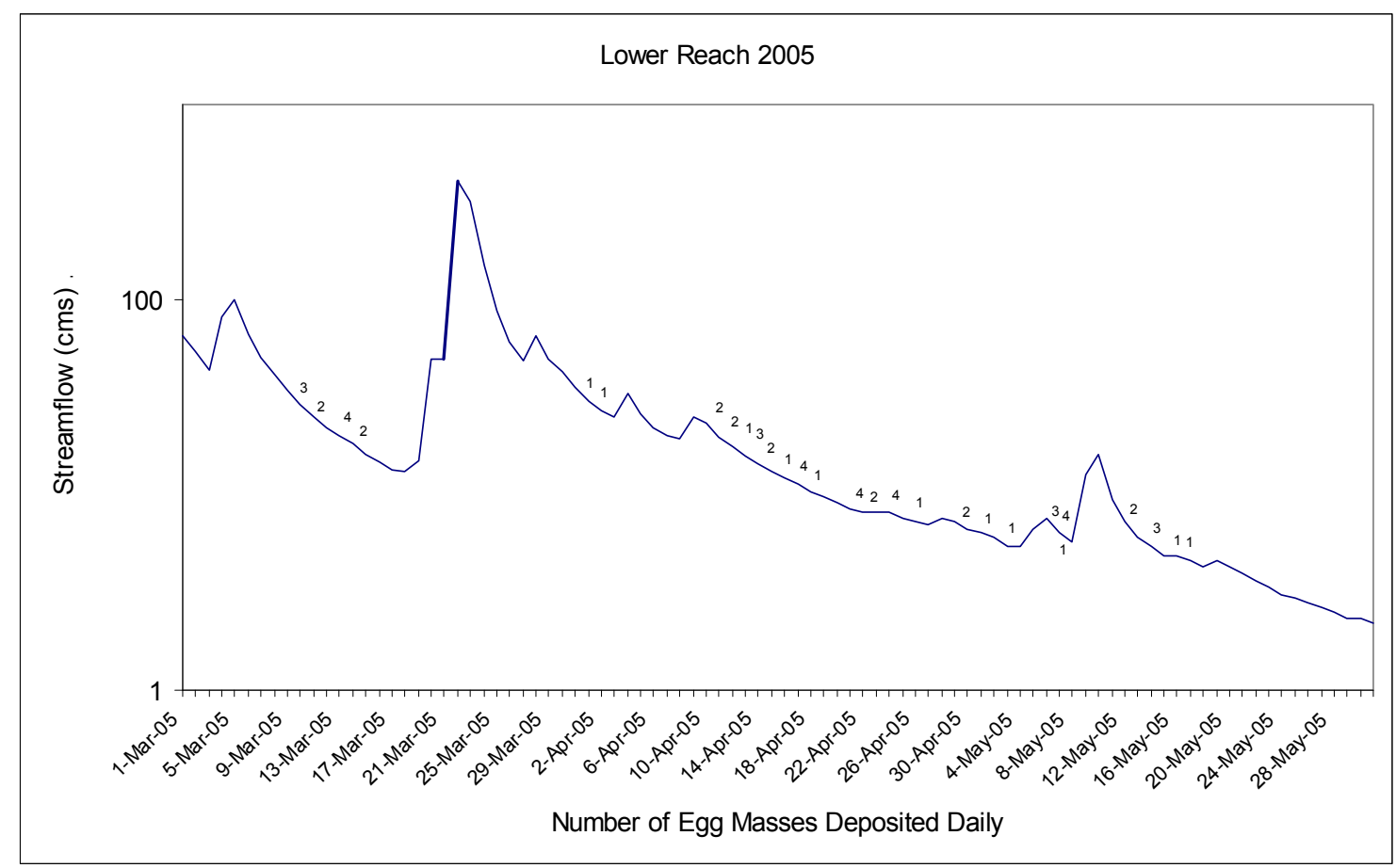

FIGURE 6.-Stream flow in association with daily oviposition on the lower reach of Coyote Creek in 2005. Numbers indicate the number of new egg masses observed during Upper Reach 2005

FIGURE 7.- Stream flow in association with daily oviposition on the upper reach of Coyote Creek in 2005. Numbers indicate the number of new egg masses observed during surveys. 


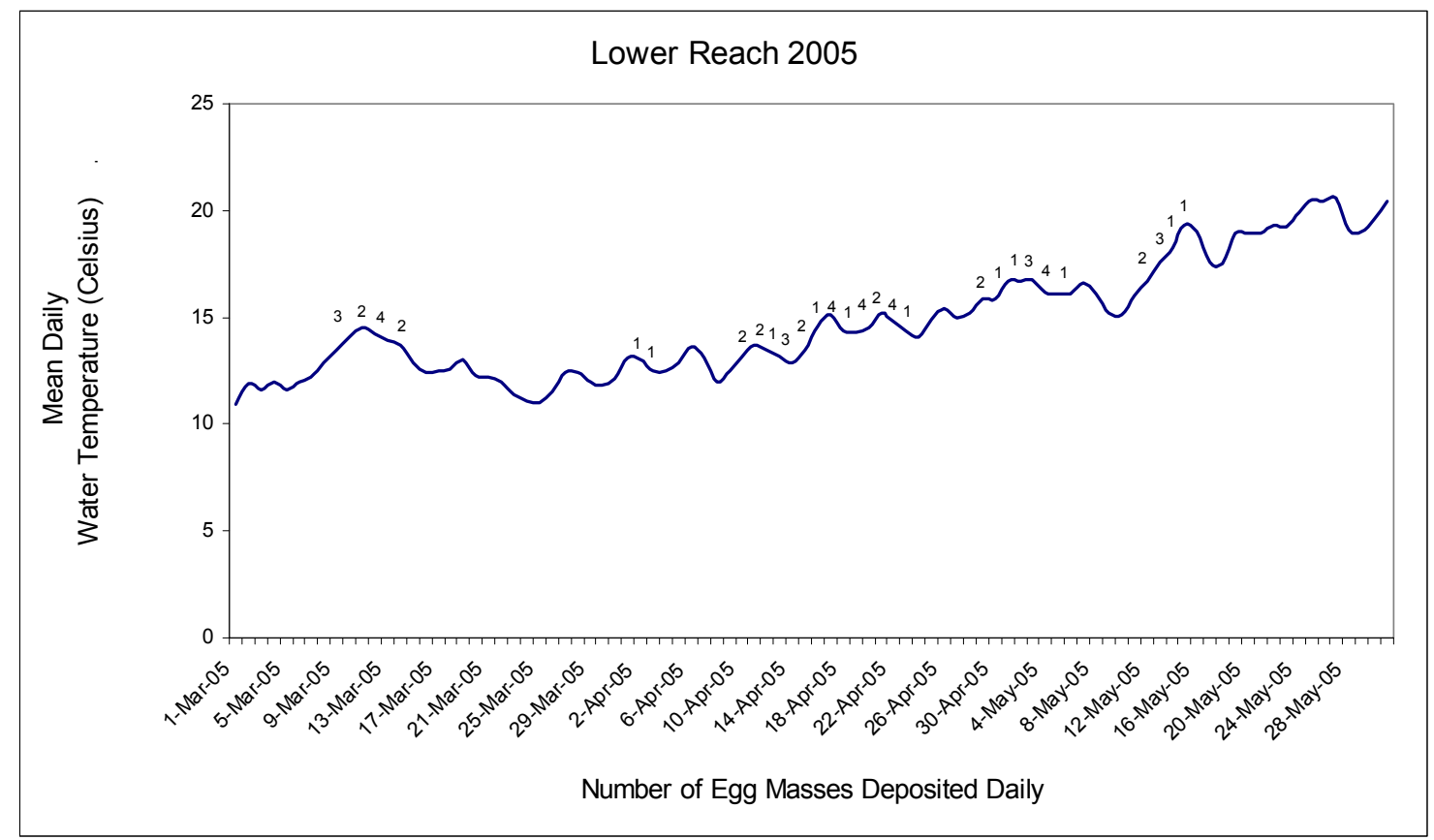

FIGURE 8.-Water temperature in association with daily oviposition on the lower reach of Coyote Creek in 2005.

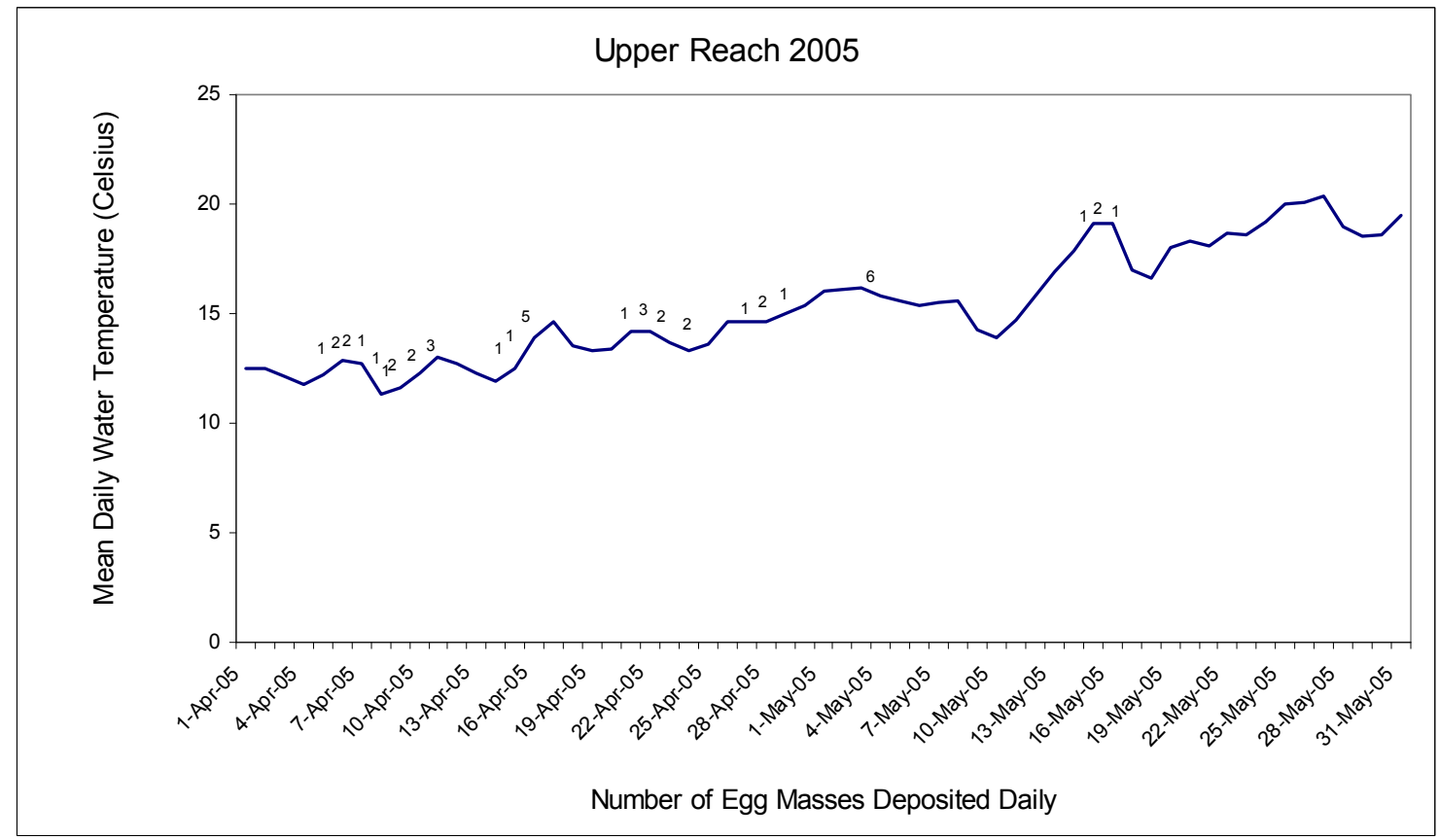

FIGURE 9.-Water temperature in association with daily oviposition on the upper reach of Coyote Creek in 2005. 


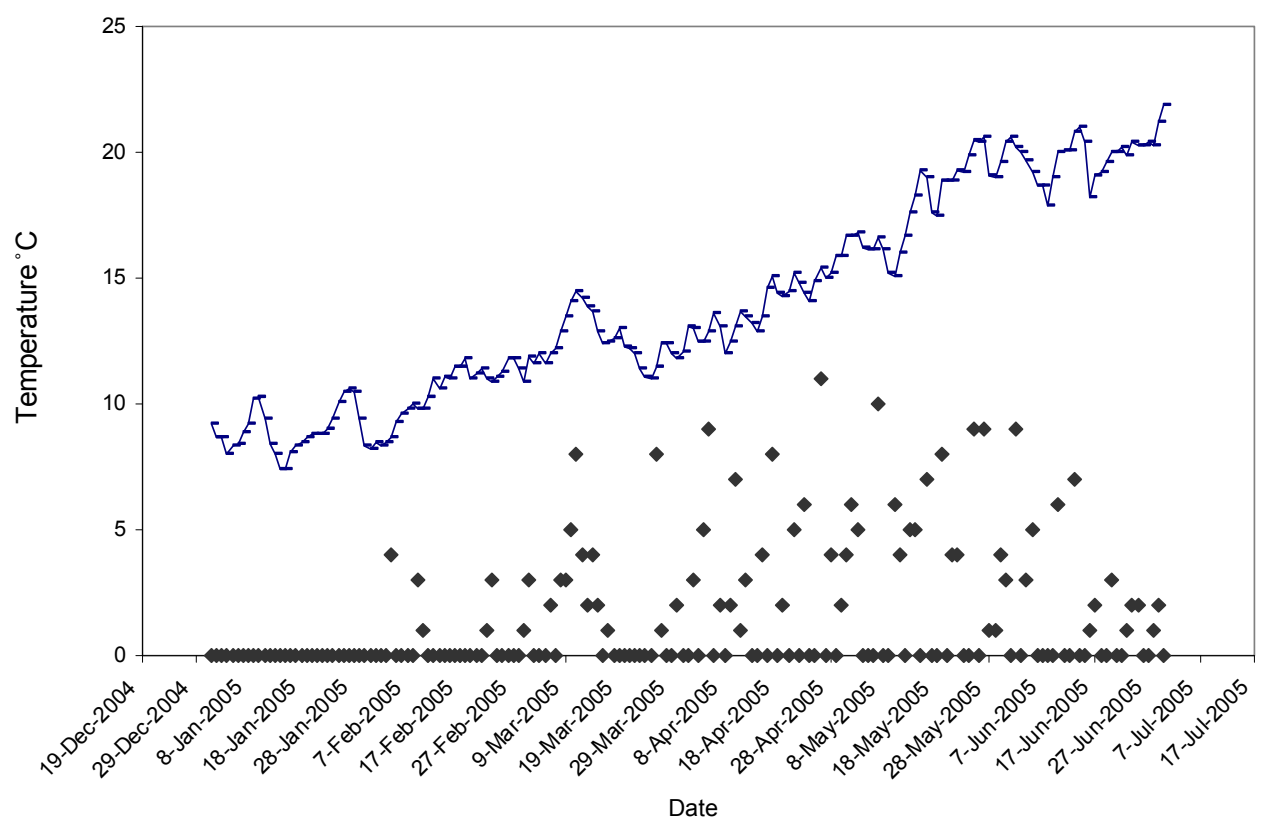

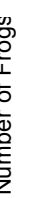

FIGURE 10.- Number of frogs observed during lower reach main stem site surveys and recorded daily mean water temperatures during the pre-breeding/breeding season in 2005.

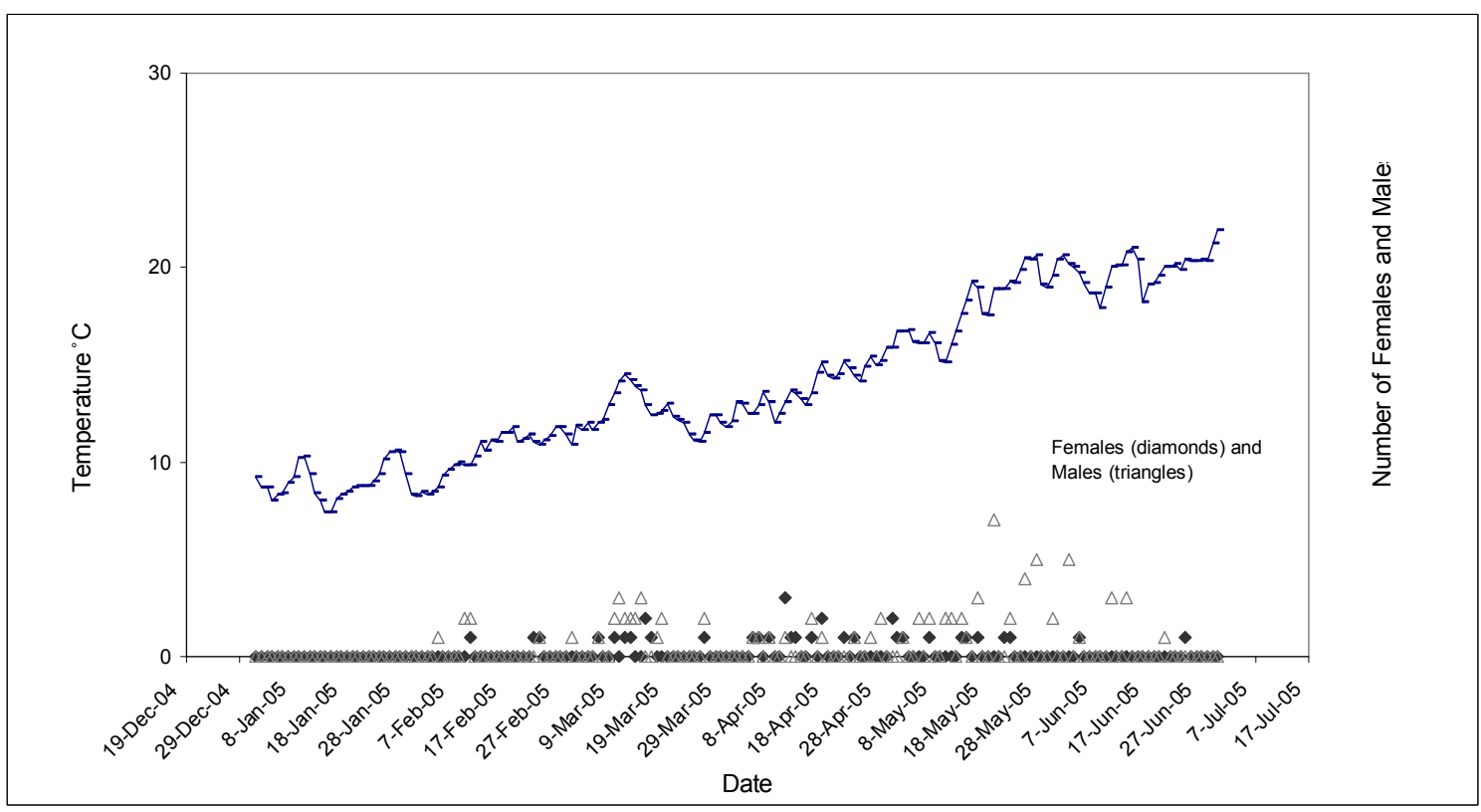

FIGURE 11.-Number of female and male frogs observed during surveys and recorded mean daily water temperatures during the pre-breeding/breeding season in 2005 . 


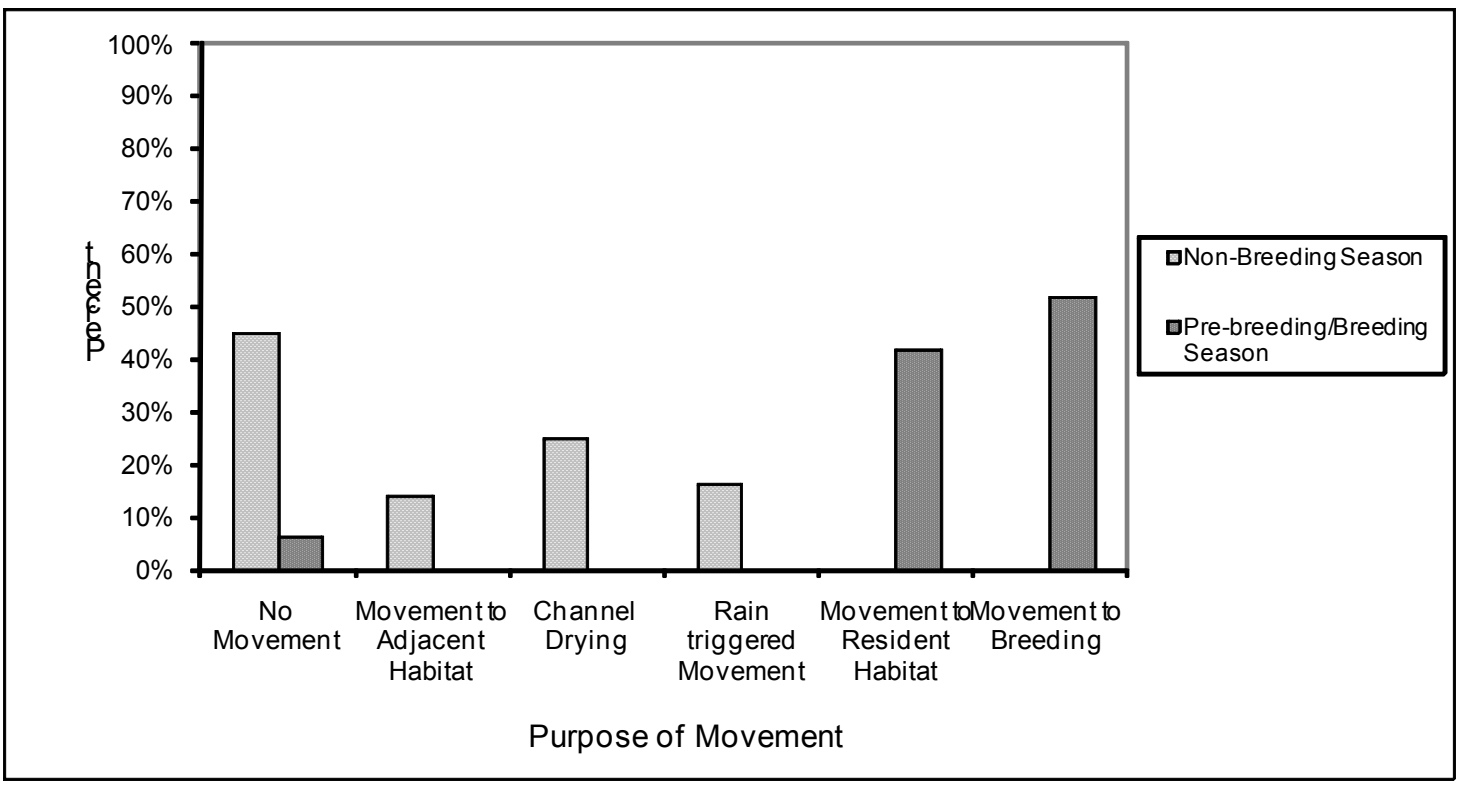

FIGURE 12.--Purpose for maximum movement of recaptured frogs during different seasons.

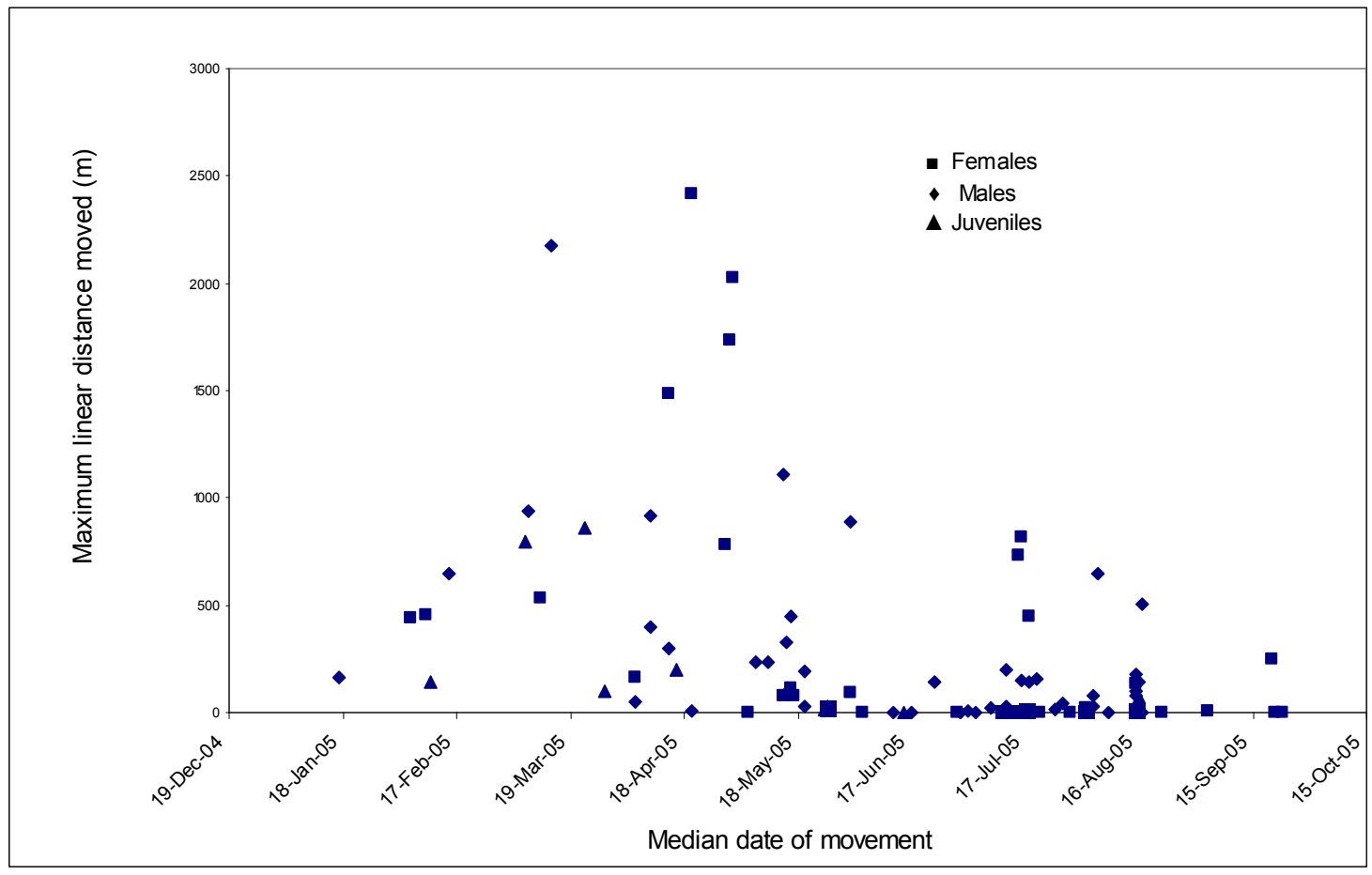

FIGURE 13.- Maximum distances traveled for individual frogs during the prebreeding/breeding and non-breeding seasons. 


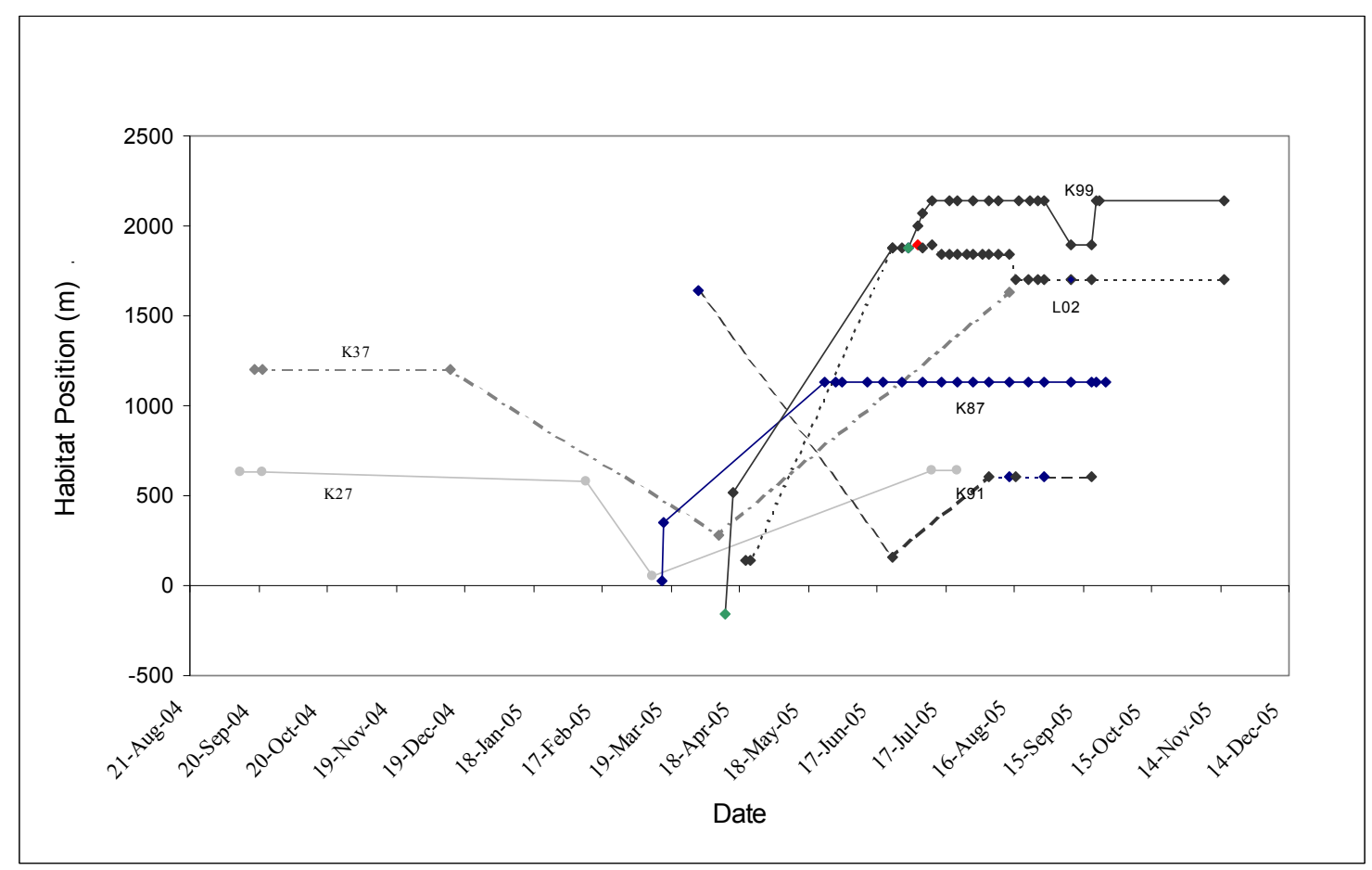

FIGURE 14.-Movement histories of individual females that resided in Dexter Creek during the non-breeding season. Negative y axis movements were distances traveled on the main stem from the confluence with Dexter Creek.

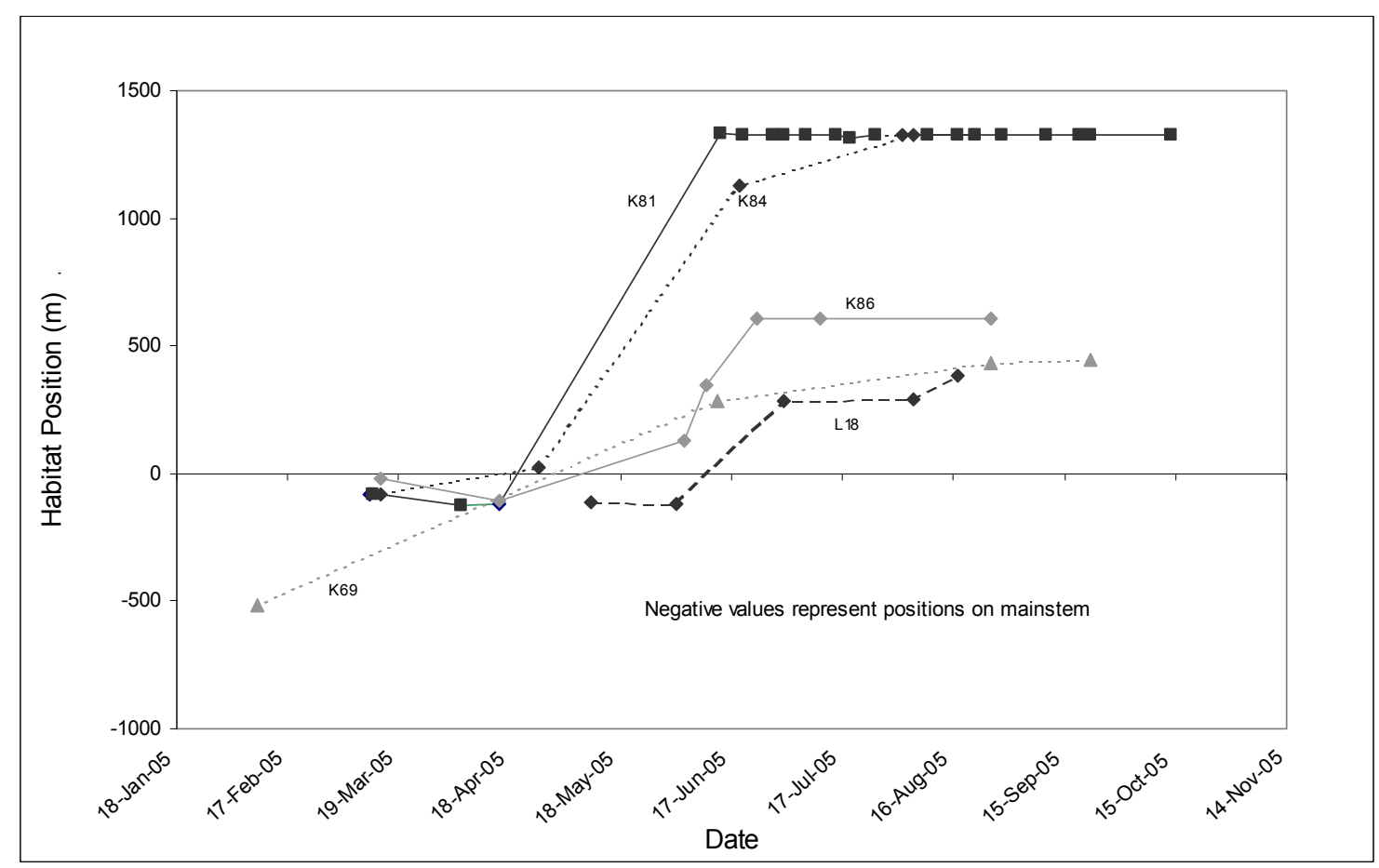

FIGURE 15.--Movement histories of individual males that resided in Dexter Creek during the non-breeding season. Negative y axis movements were distances traveled on the main stem from the confluence with Dexter Creek. 


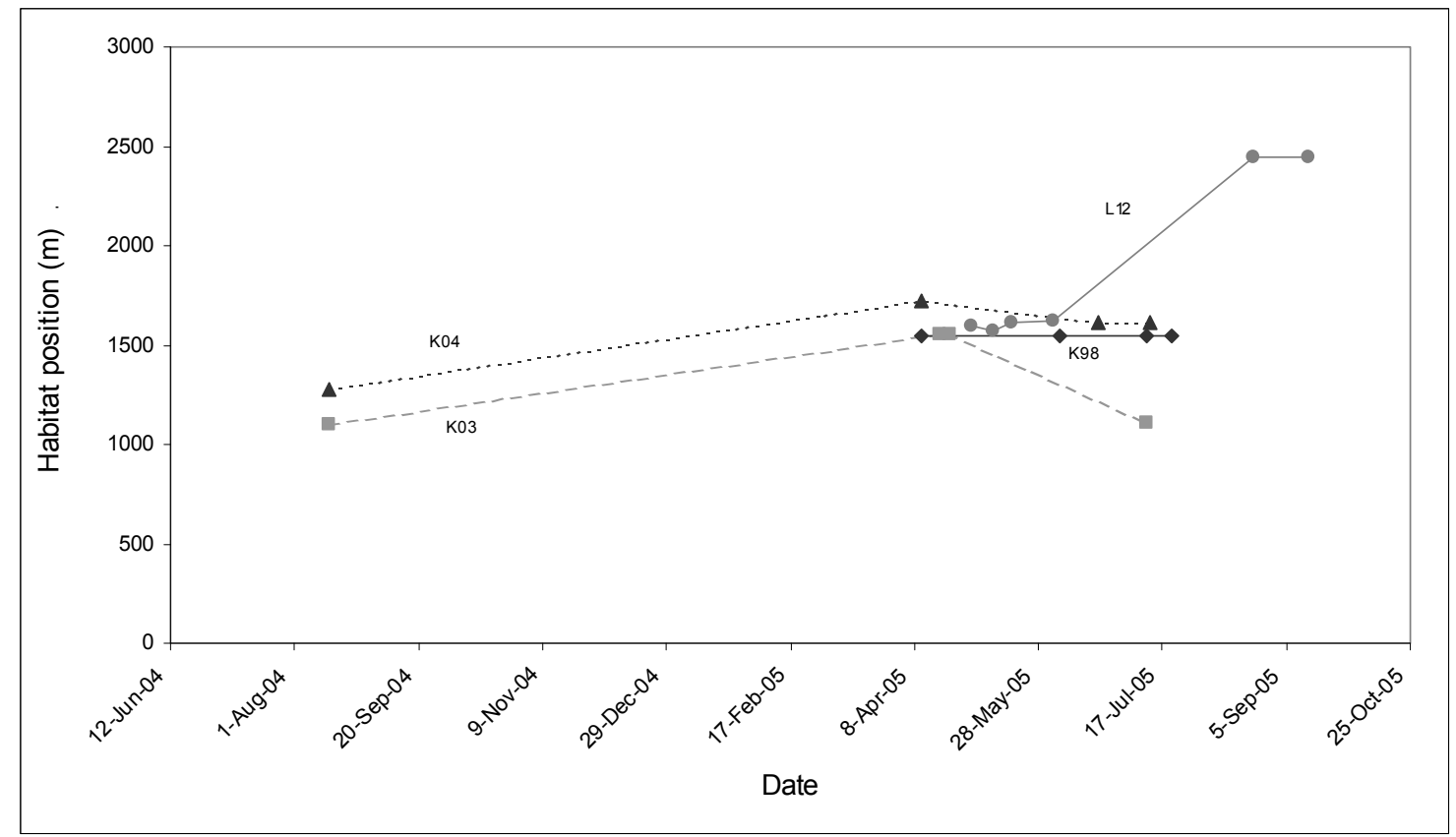

FIGURE 16.-Movement histories of individual main stem resident females on Coyote Creek.

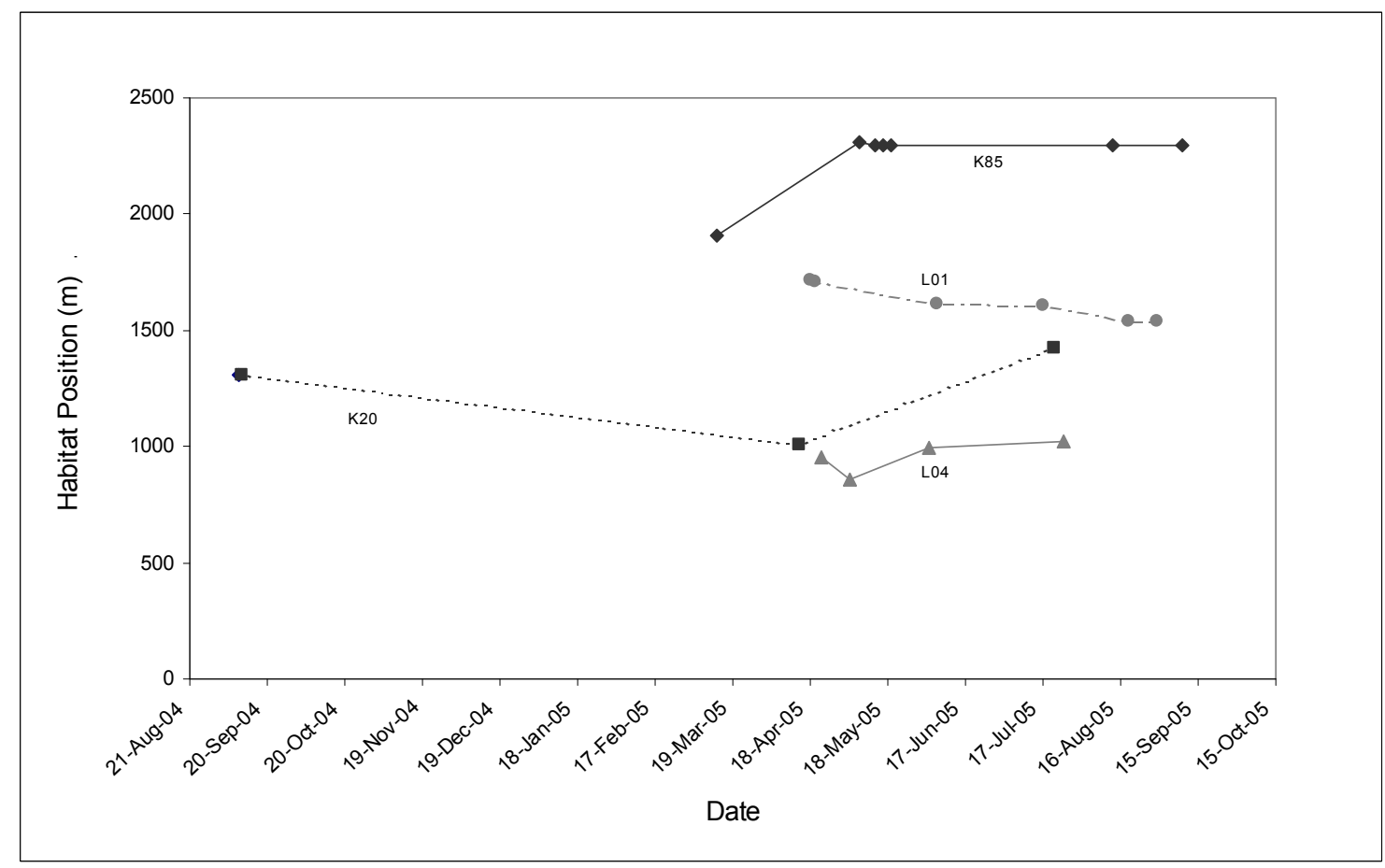

FIGURE 17.- Movement histories of individual main stem resident males on Coyote Creek. 


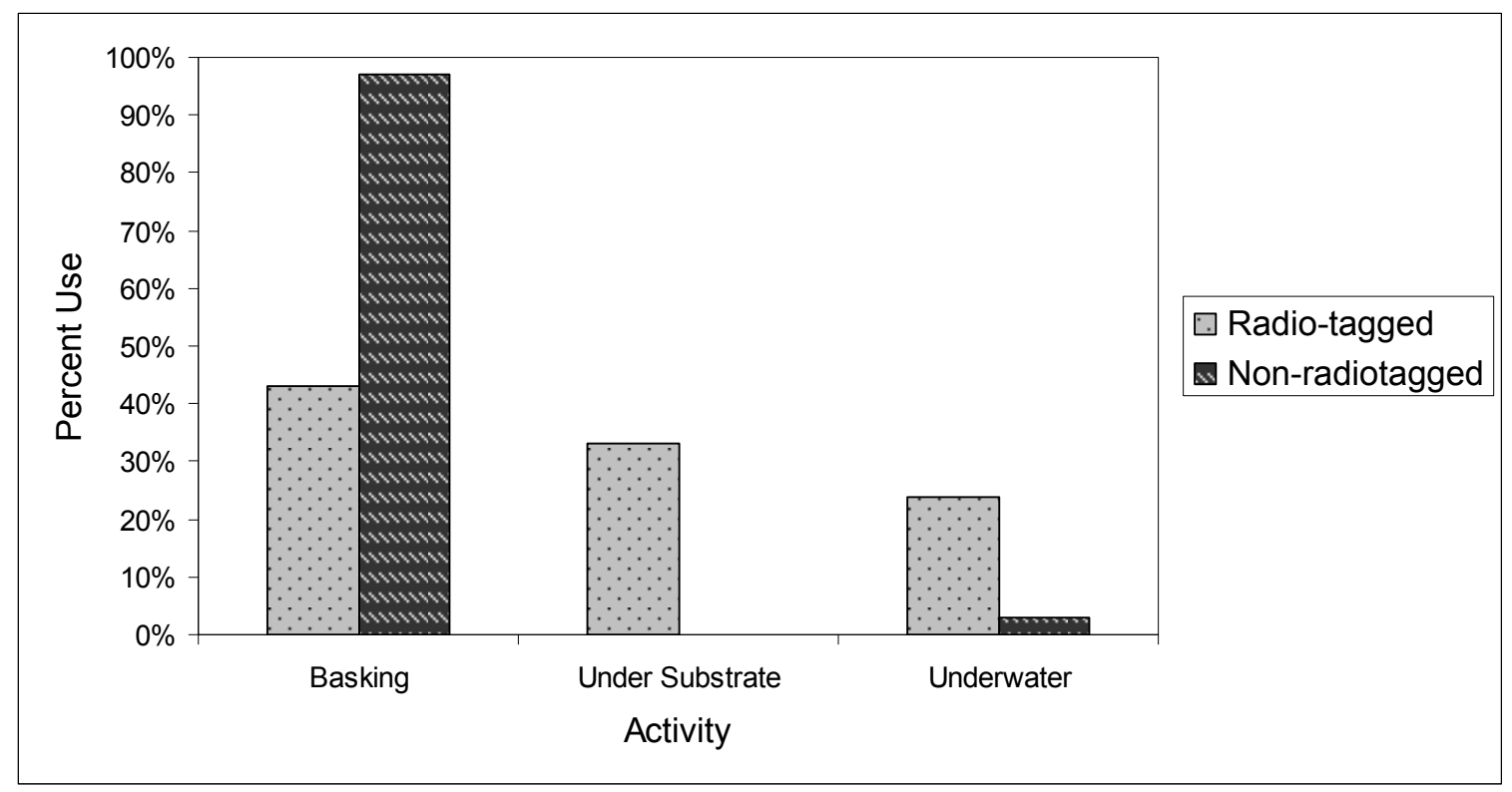

FIGURE 18.- Observed activities of radiotagged versus non-radiotagged frogs on Dexter Creek in 2005.

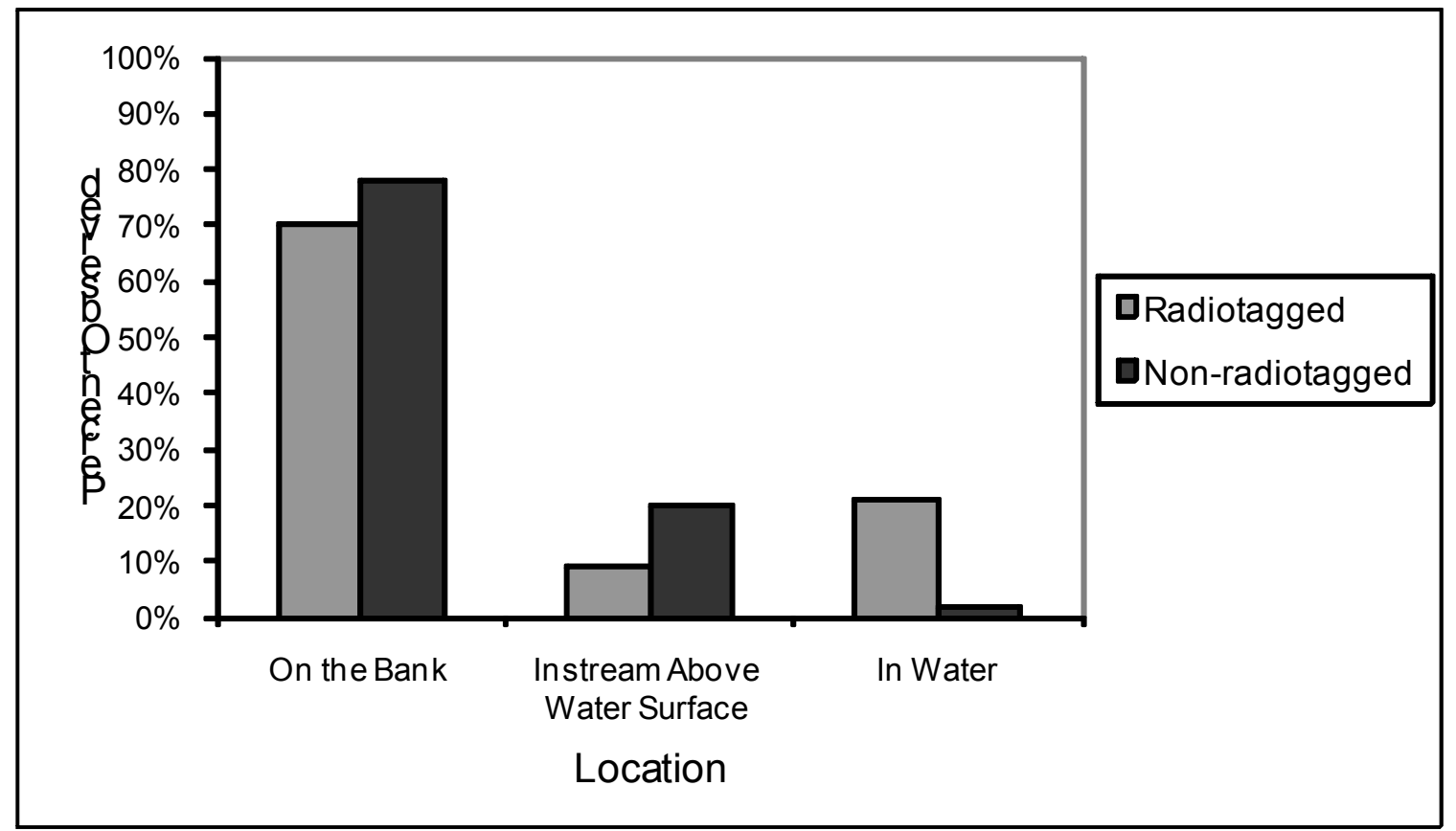

FIGURE 19.- - Location of radiotagged versus non-radiotagged frogs in relation to the active channel on Dexter Creek. 


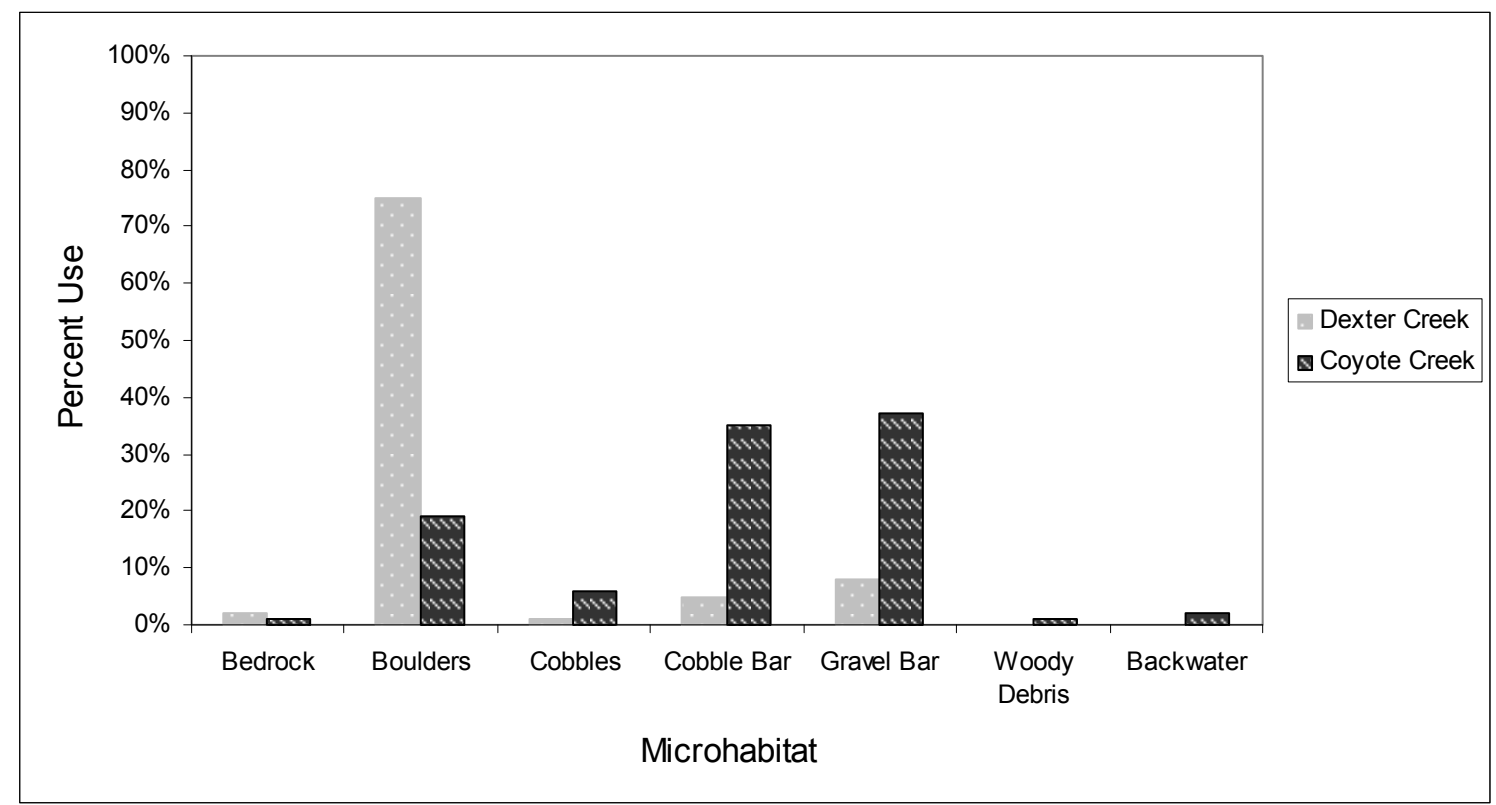

FIGURE 20.-Microhabitat use by observed non-radiotagged foothill yellow-legged frogs on Coyote and Dexter Creeks.

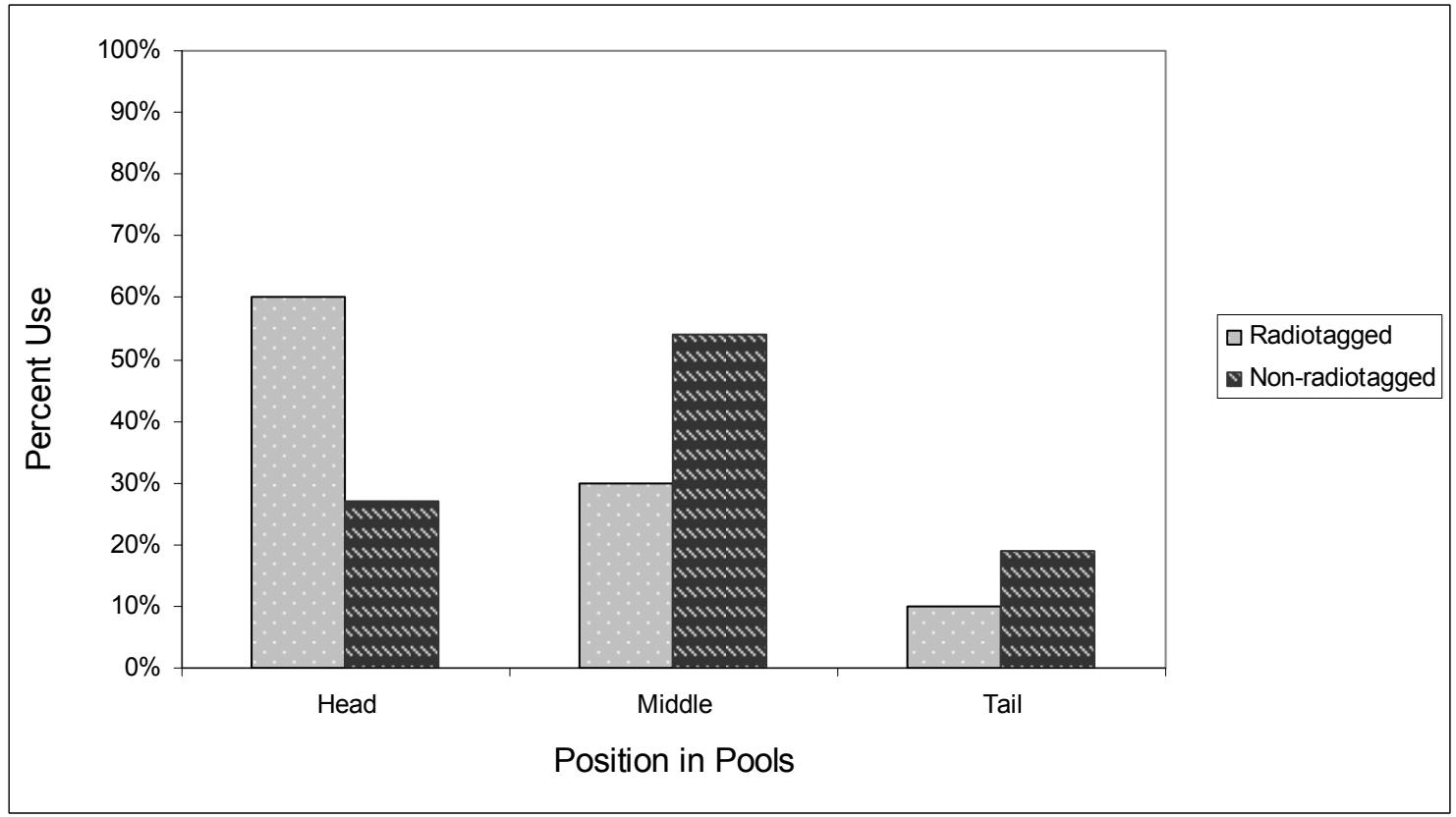

FIGURE 21.-Position in pools for radiotagged versus non-radiotagged foothill yellowlegged frogs on Dexter Creek. 


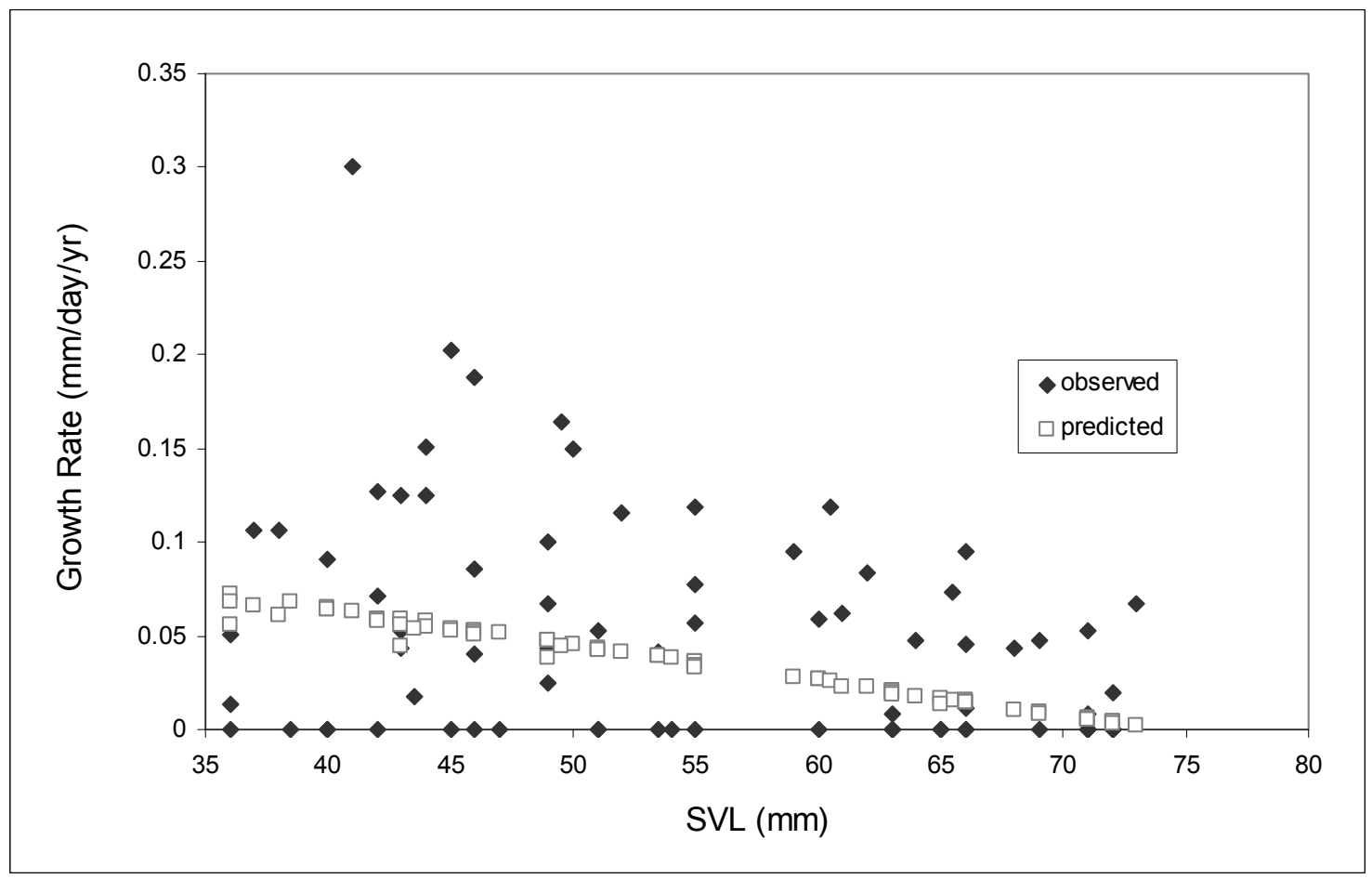

FIGURE 22.-Daily observed and predicted adult female growth rates.

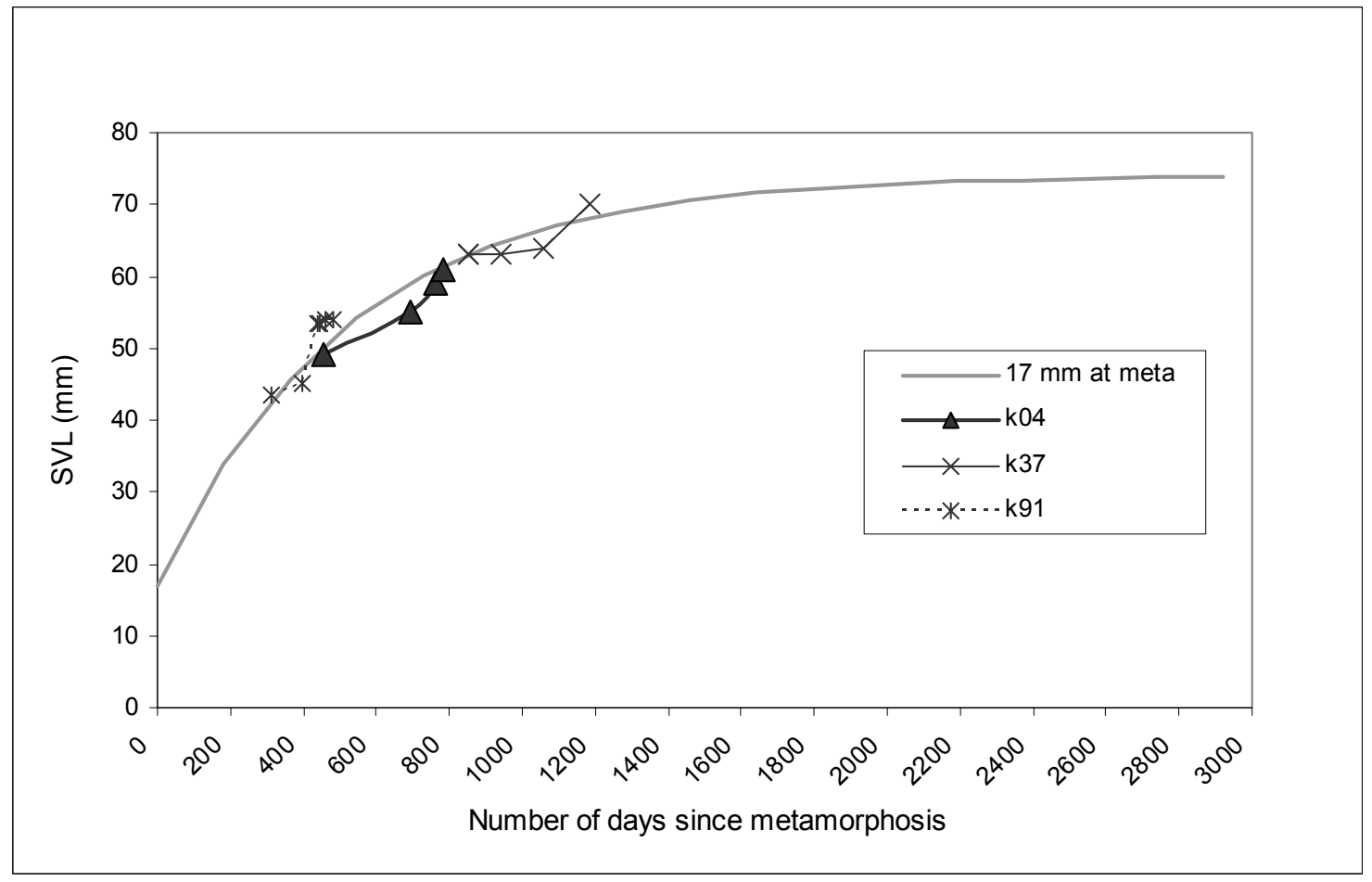

FIGURE 23.- Observed individual female growth rates versus growth curves for small metamorphs. 


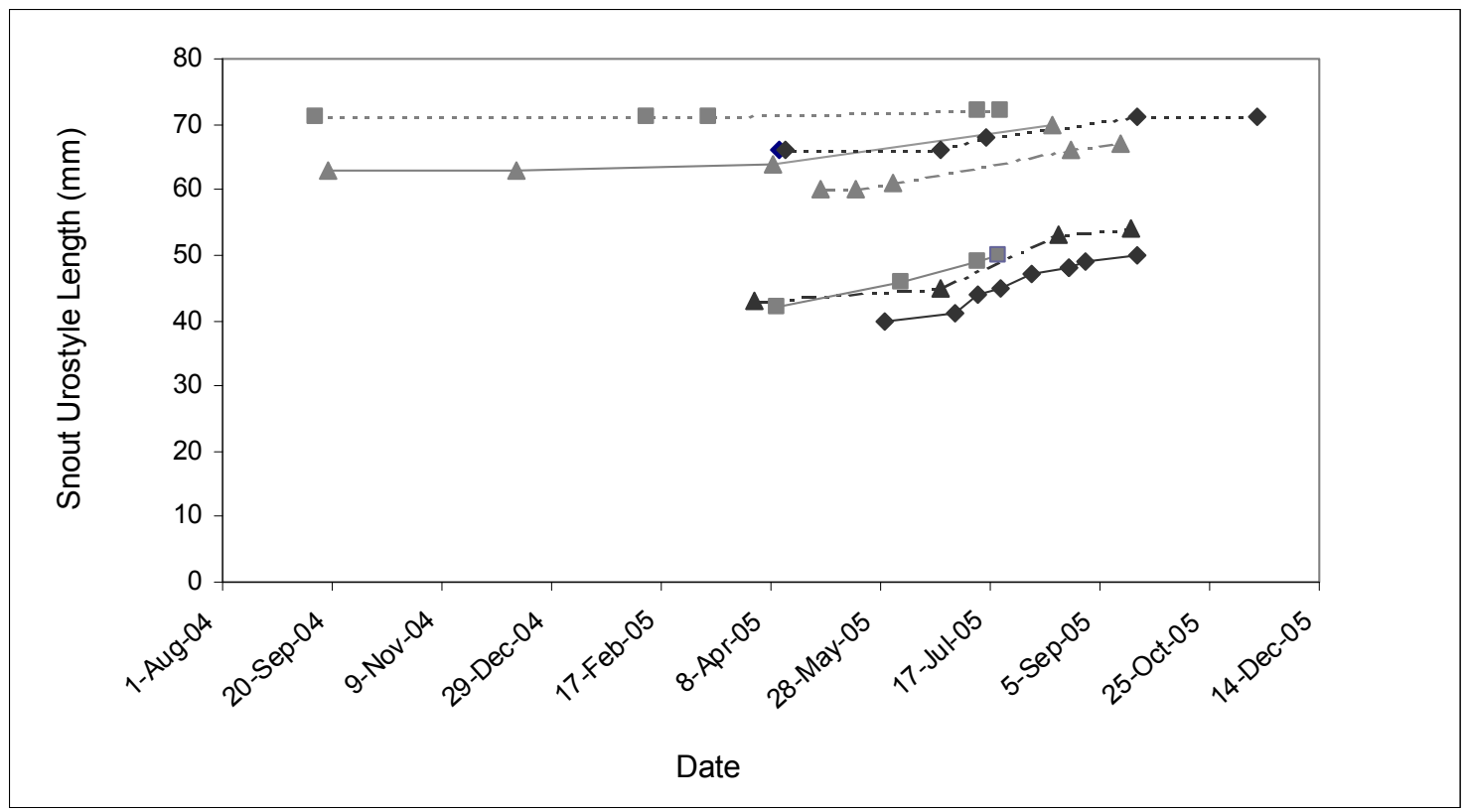

FIGURE 24.- Growth curves for selected female foothill yellow-legged frogs during 2004-2005.

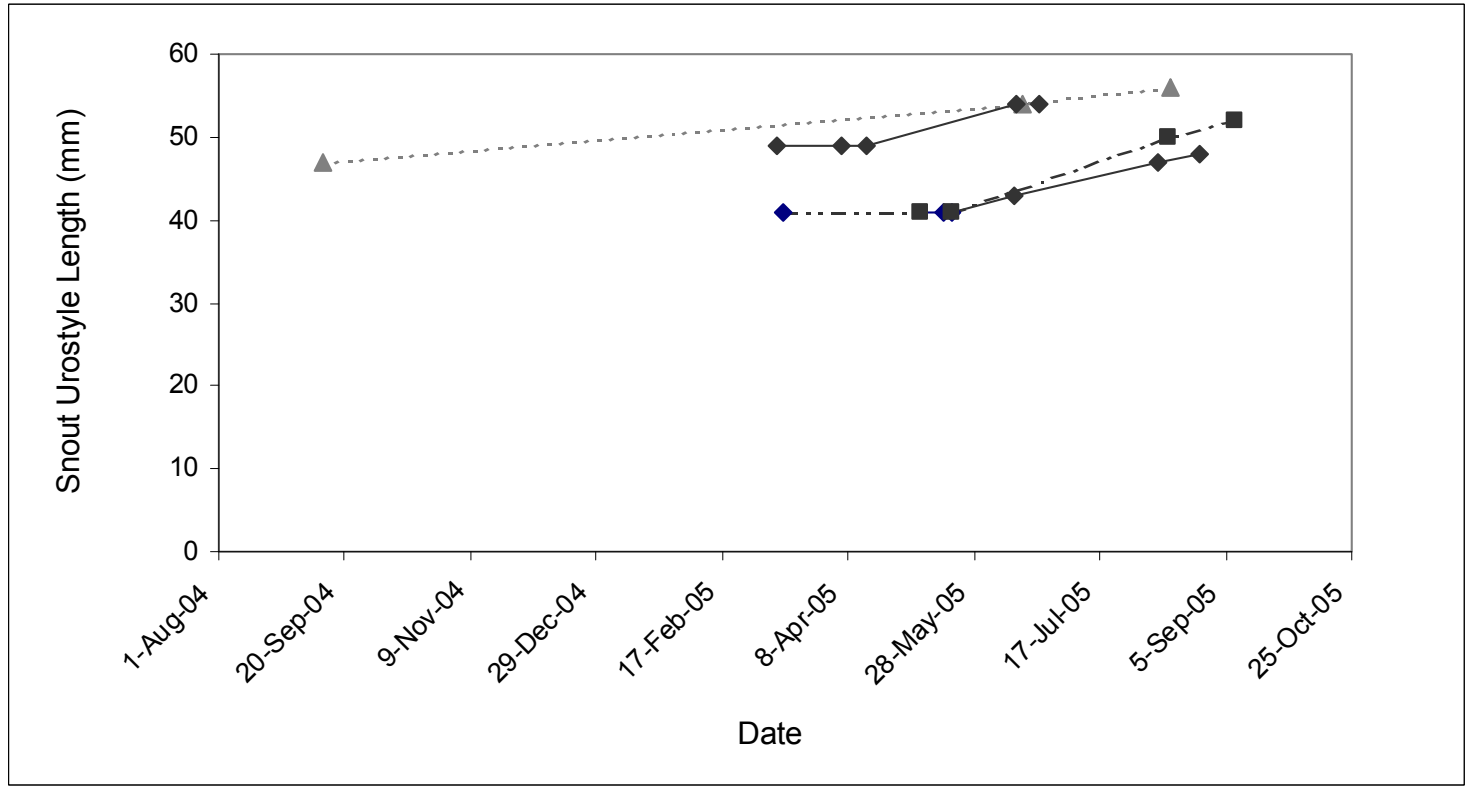

FIGURE 25.- Growth curves for selected male frogs during 2004-2005. 


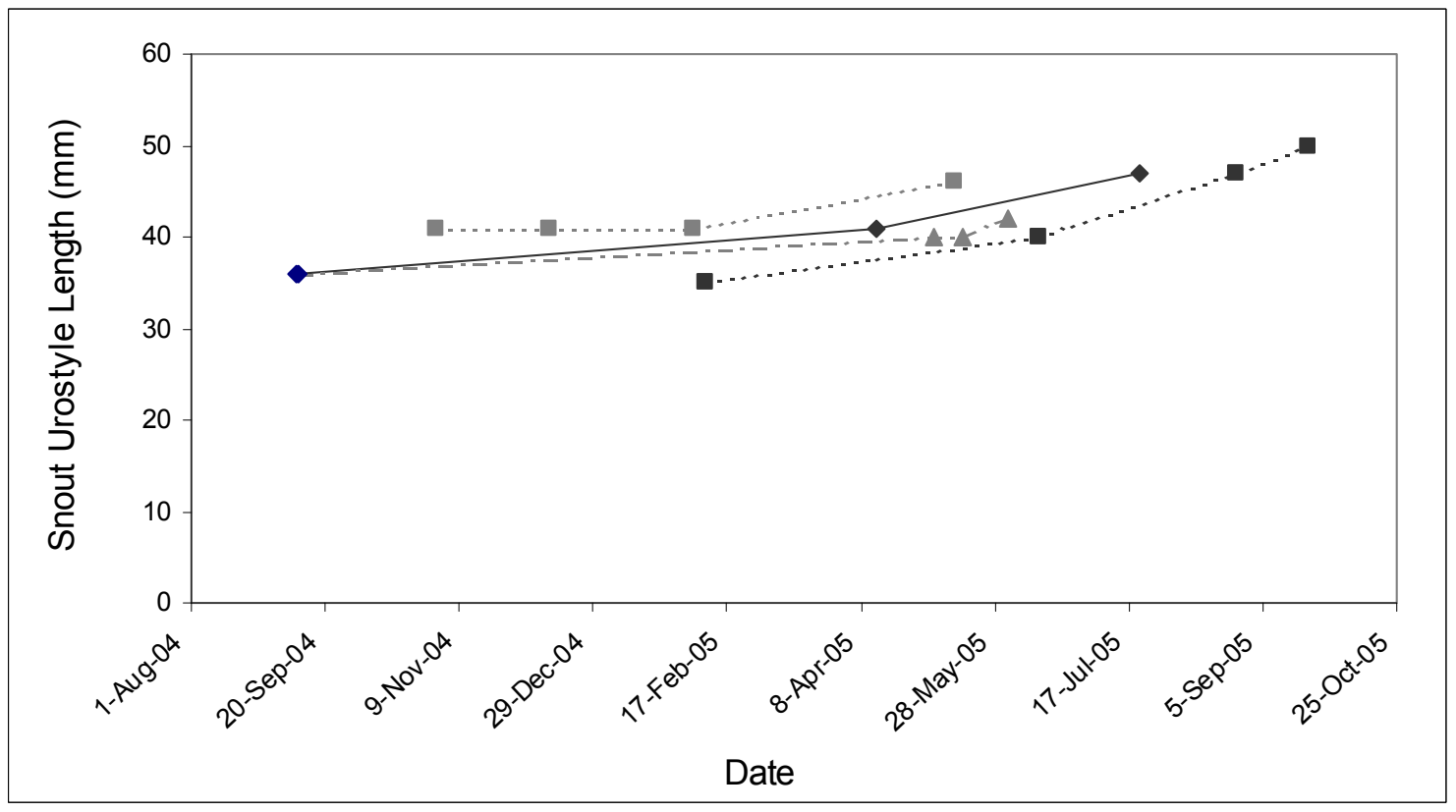

FIGURE 26.- Growth curves for selected male frogs during 2004-2005.

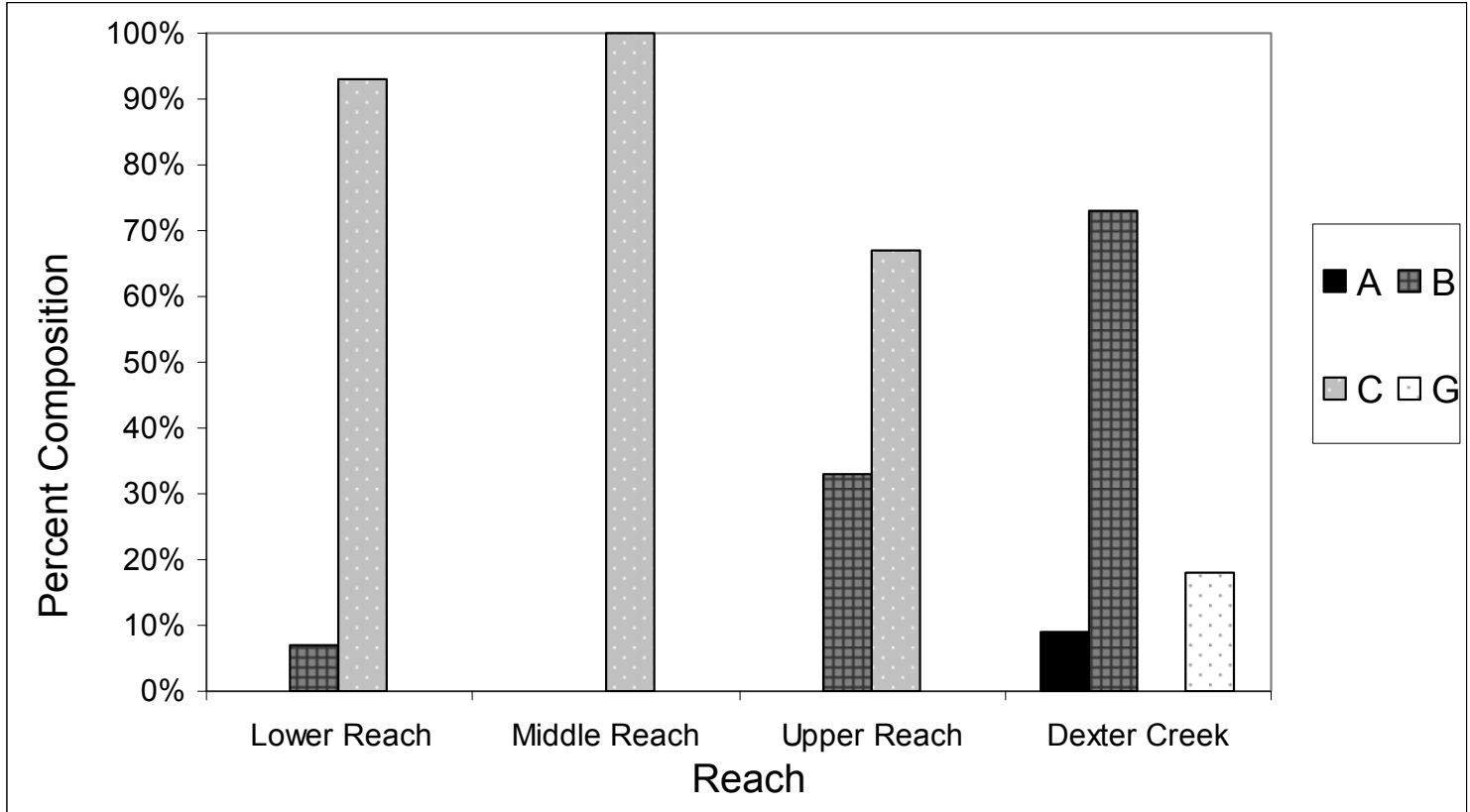

FIGURE 27.--Rosgen Level II Channel morphology composition by reach for the Coyote Creek study area. 


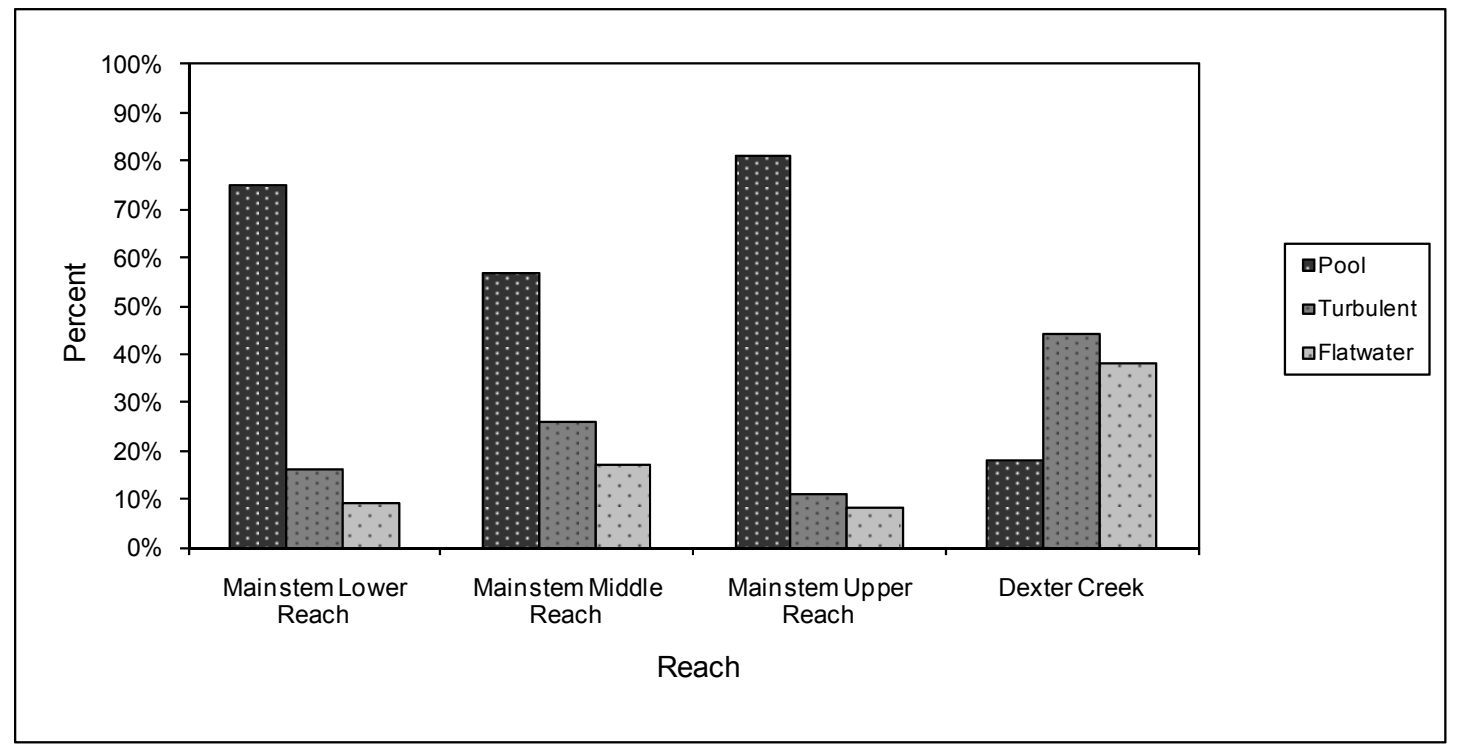

FIGURE 28.-Mesohabitat composition for the Coyote Creek study area.

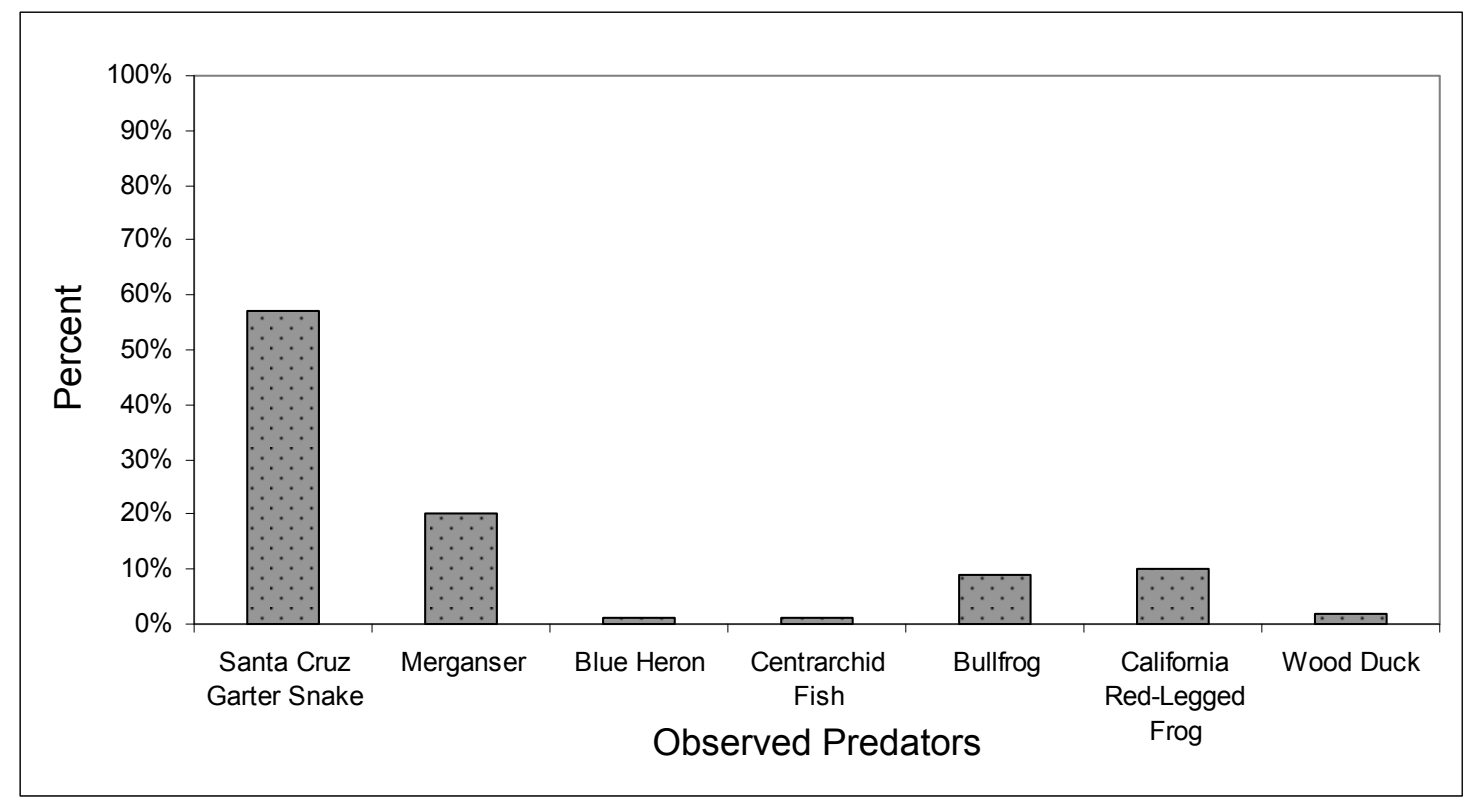

FIGURE 29.- Observed diurnal predator composition on the main stem of upper Coyote Creek during 2004-2005. 


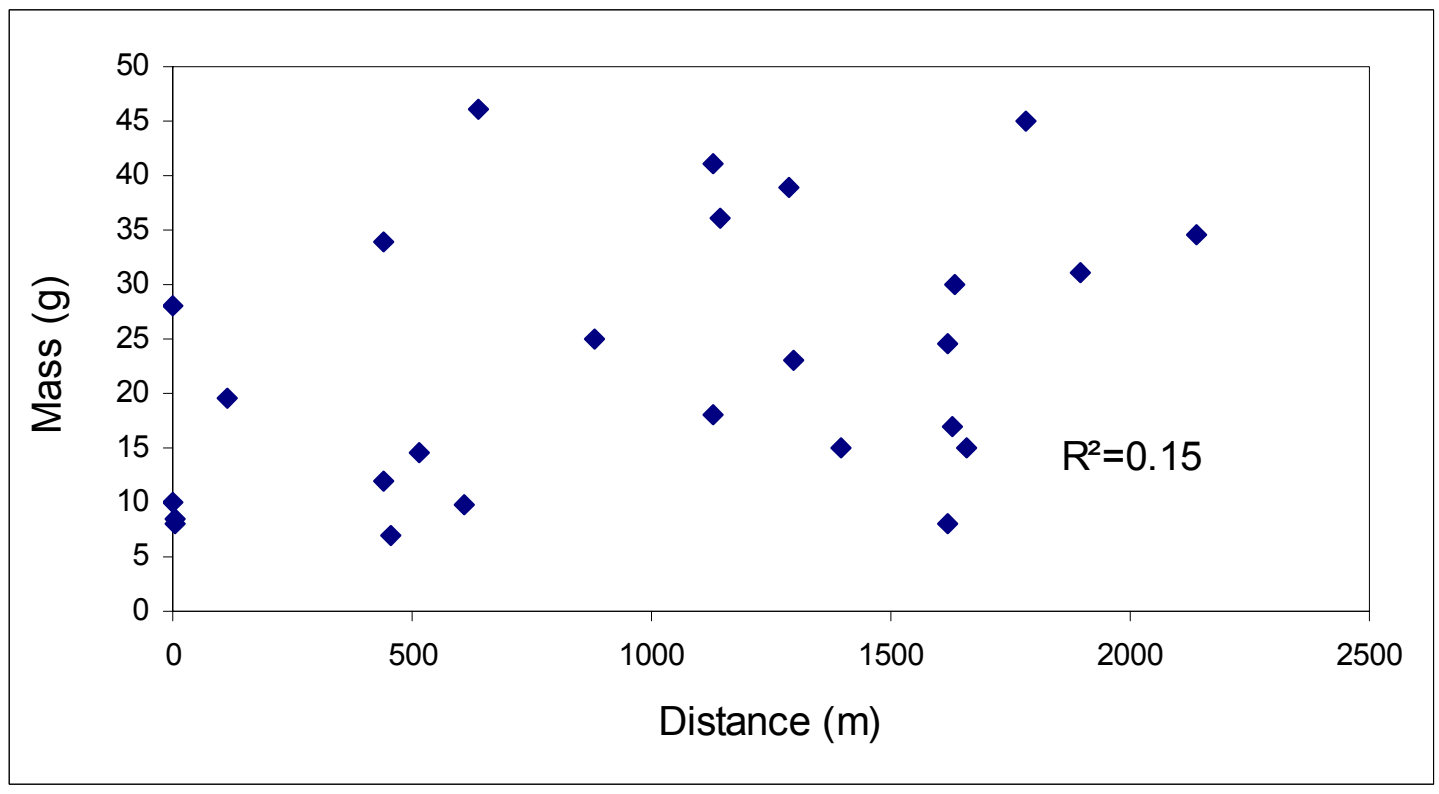

FIGURE 30.-Female body mass of resident frogs versus distance from the breeding area.

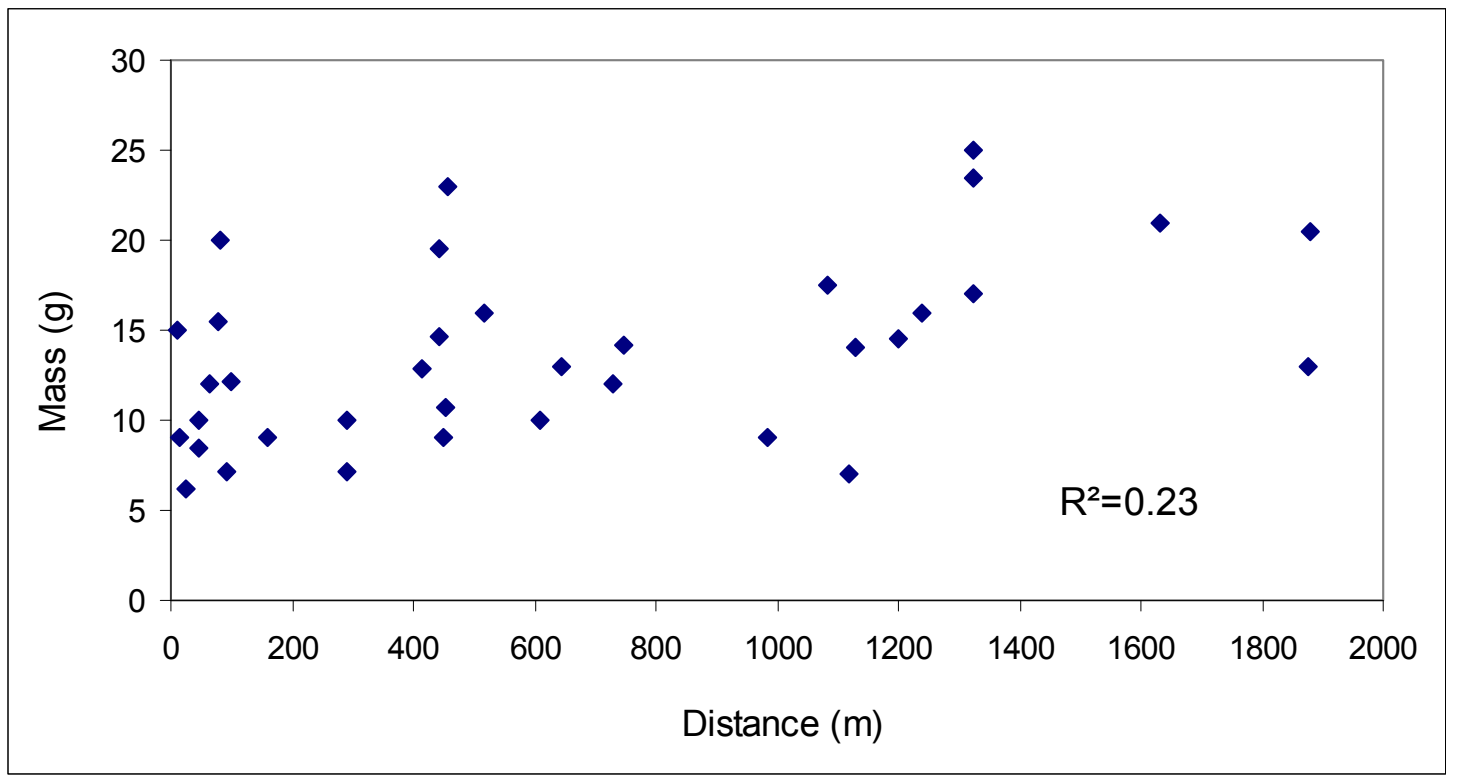

FIGURE 31.-Male body mass of resident frogs versus distance from the breeding area. 


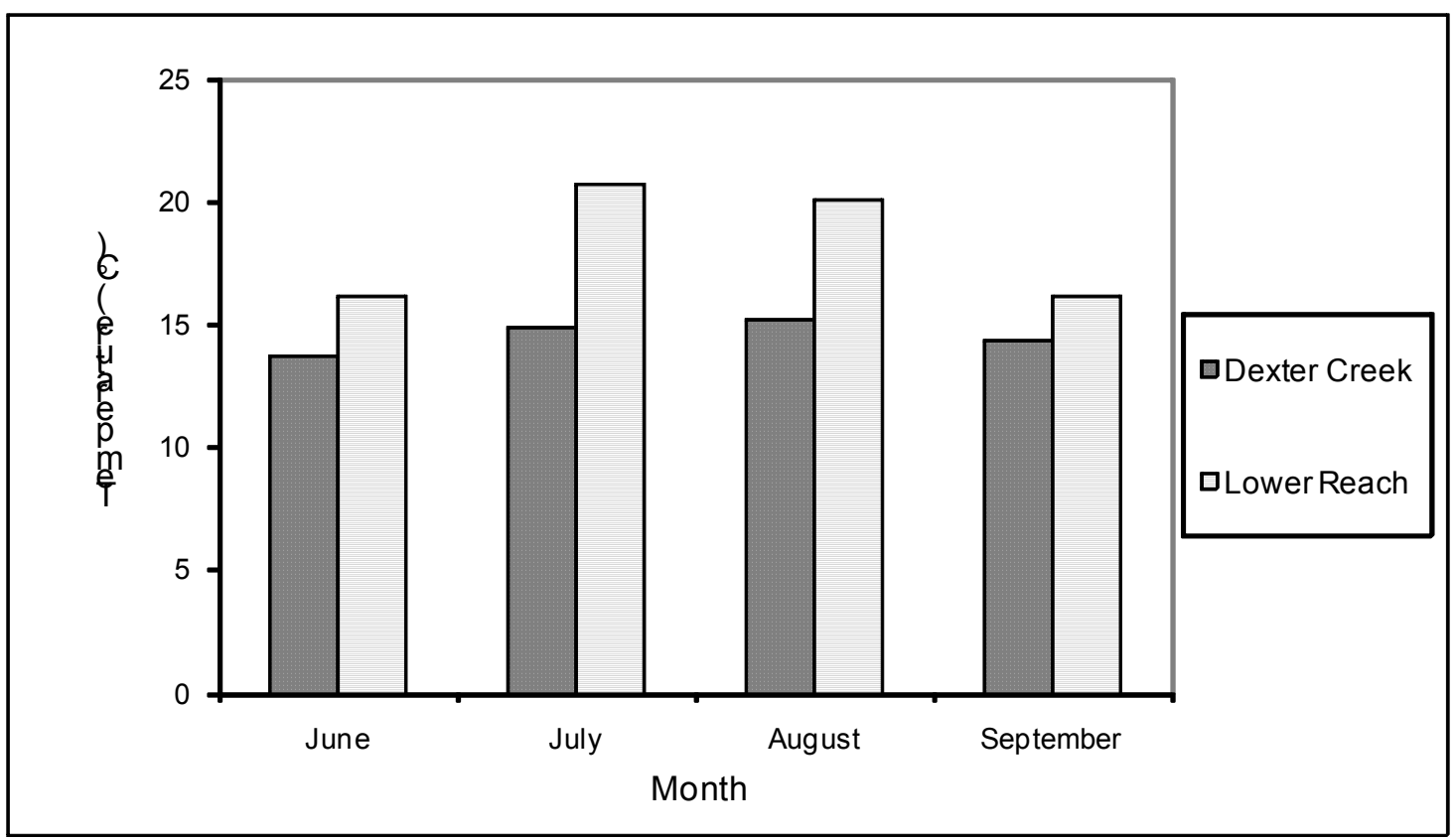

FIGURE 32.-Comparison of monthly daily mean air temperatures during summer 2005, between the lower reach of Coyote Creek and Dexter Creek.

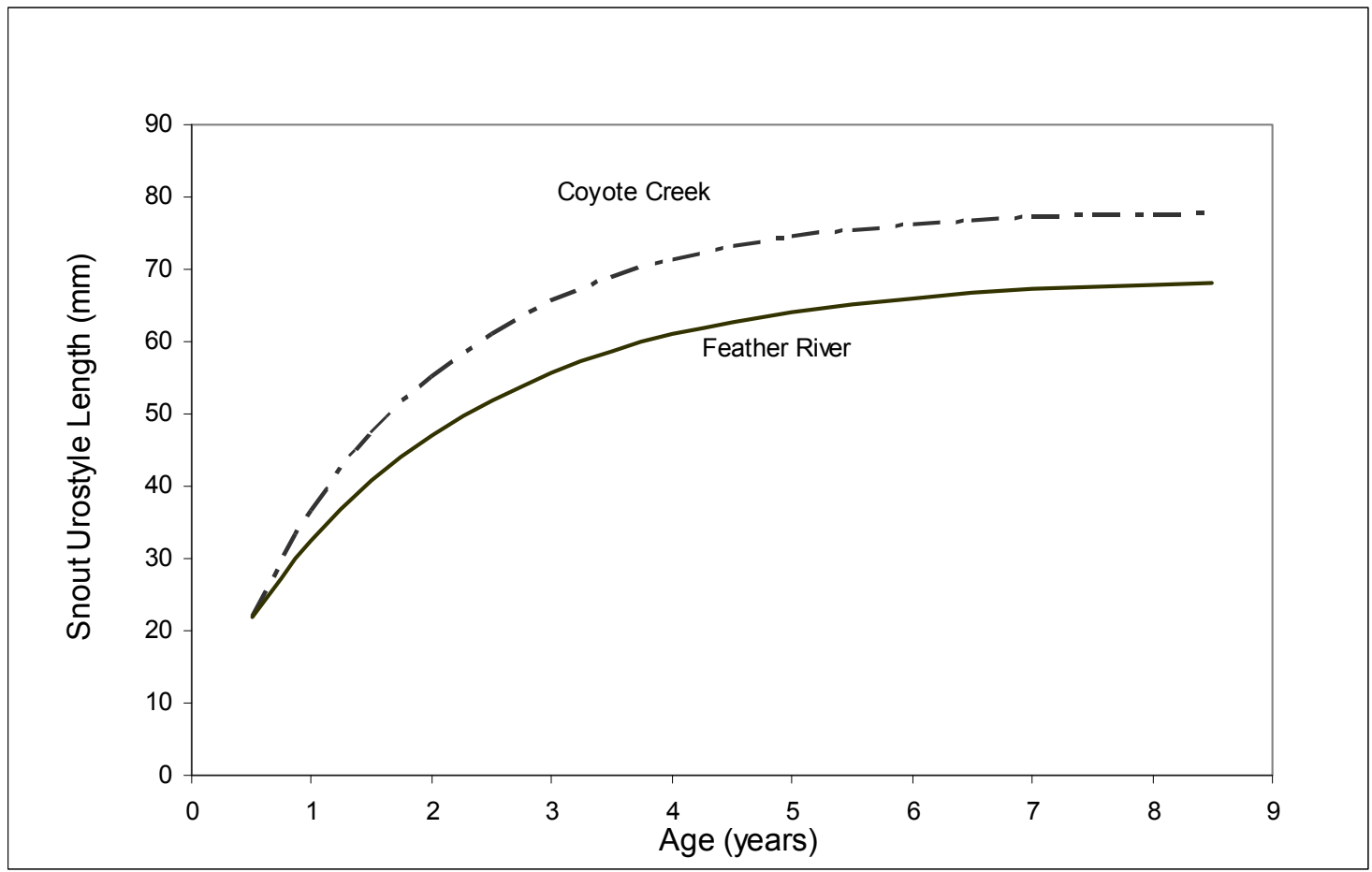

FIGURE 33.- Comparison of growth rate predicted by VBGE for Coyote Creek and Feather River setting metamorphosis at $22 \mathrm{~mm}$. 
TABLES 
TABLE 1.-Foothill yellow-legged frog 2004 and 2005 breeding season summary on Coyote Creek upstream of Coyote Reservoir in Santa Clara County, CA.

\begin{tabular}{cccccc}
\hline & $\begin{array}{c}\text { Start Date } \\
\text { of Breeding }\end{array}$ & $\begin{array}{c}\text { Finish Date } \\
\text { of Breeding }\end{array}$ & $\begin{array}{c}\text { Breeding Season } \\
\text { Length (Days }\end{array}$ & $\begin{array}{c}\text { Total Egg Mass } \\
\text { Number }\end{array}$ & $\begin{array}{c}\text { Egg Mass } \\
\text { Density (mass/m) }\end{array}$ \\
\hline $\begin{array}{c}\text { 2004 } \\
\text { Lower Reach }\end{array}$ & $3 / 7 / 2004$ & $3 / 31 / 2004$ & 24 & & \\
Upper Reach & $3 / 24 / 2004$ & $4 / 20 / 2004$ & 27 & 31 & 0.0172 \\
$\quad$ Total & $\mathrm{n} / \mathrm{a}$ & $\mathrm{n} / \mathrm{a}$ & 44 & 72 & 0.0126 \\
2005 & & & & & 0.0149 \\
Lower Reach & $3 / 12 / 2005$ & $5 / 14 / 2005$ & 63 & 59 & 0.0248 \\
Upper Reach & $4 / 4 / 2005$ & $5 / 16 / 2005$ & 42 & 44 & 0.0179 \\
Total & $\mathrm{n} / \mathrm{a}$ & $\mathrm{n} / \mathrm{a}$ & 65 & 103 & 0.0214 \\
2006 & & & & & \\
Lower Reach & $3 / 9 / 2006$ & $\mathrm{n} / \mathrm{a}$ & $\mathrm{n} / \mathrm{a}$ & $\mathrm{n} / \mathrm{a}$ & $\mathrm{n} / \mathrm{a}$ \\
Upper Reach & $\mathrm{n} / \mathrm{a}$ & $\mathrm{n} / \mathrm{a}$ & $\mathrm{n} / \mathrm{a}$ & $\mathrm{n} / \mathrm{a}$ & $\mathrm{n} / \mathrm{a}$ \\
\hline
\end{tabular}

TABLE 2.- Hatching success (egg mass survival) of egg masses on Coyote Creek 20042005.

\begin{tabular}{cccccc}
\hline & $\begin{array}{c}\text { Number of Egg } \\
\text { Masses }\end{array}$ & Scoured/Missing & Hatching Success & $\begin{array}{c}\text { Mean Number } \\
\text { of Days to } \\
\text { Hatch }\end{array}$ & Range \\
\hline $\begin{array}{c}2004 \\
\text { Lower Reach }\end{array}$ & 41 & & & & \\
Upper Reach & 31 & 0 & $100 \%$ & 13 & $10-14$ \\
$\quad$ Total & 72 & 0 & $100 \%$ & no data & no data \\
2005 & & 0 & $100 \%$ & & \\
Lower Reach & 59 & 16 & $73 \%$ & 12 & $6-26$ \\
Upper Reach & 44 & 0 & $100 \%$ & 14 & $8-19$ \\
Total & 103 & 16 & $85 \%$ & & \\
\hline
\end{tabular}


TABLE 3.-Mesohabitat use percentages for 176 foothill yellow-legged frog egg masses laid within the study area on Coyote Creek in 2004-2005.

\begin{tabular}{ccccc}
\hline & $\begin{array}{c}\text { Proportion of Egg } \\
\text { Masses in Pools }\end{array}$ & $\begin{array}{c}\text { Proportion of Egg } \\
\text { Masses in } \\
\text { Flatwater }\end{array}$ & $\begin{array}{c}\text { Number of } \\
\text { Mesohabitats } \\
\text { Utilized }\end{array}$ & $\begin{array}{c}\text { Percentage of } \\
\text { same } \\
\text { Mesohabitats used } \\
\text { in 2005 from 2004 }\end{array}$ \\
\hline $\begin{array}{c}\text { 2004 } \\
\text { Lower Reach }\end{array}$ & $97.5 \%$ & $2.5 \%$ & 8 & $\mathrm{n} / \mathrm{a}$ \\
Upper Reach & $100 \%$ & $0 \%$ & 8 & $\mathrm{n} / \mathrm{a}$ \\
2005 & $95 \%$ & $5 \%$ & 9 & $70 \%$ \\
Lower Reach & $100 \%$ & $100 \%$ & 8 & $60 \%$ \\
Upper Reach & & & & \\
\hline
\end{tabular}

TABLE 4.-Microhabitat parameter utilization for egg masses deposited within the study area on Coyote Creek in 2004-2005.

\begin{tabular}{|c|c|c|c|c|c|c|}
\hline Position in Pool & Head & Middle & Tail & & & \\
\hline \multicolumn{7}{|l|}{$\underline{2004}$} \\
\hline Lower Reach & $5 \%$ & $40 \%$ & $55 \%$ & & & \\
\hline Upper Reach & $0 \%$ & $23 \%$ & $77 \%$ & & & \\
\hline \multicolumn{7}{|l|}{2005} \\
\hline Lower Reach & $4 \%$ & $43 \%$ & $53 \%$ & & & \\
\hline Upper Reach & $2 \%$ & $75 \%$ & $23 \%$ & & & \\
\hline Microhabitat & $\begin{array}{l}\text { Submerged } \\
\text { Gravel Bar }\end{array}$ & $\begin{array}{l}\text { Submerged } \\
\text { Cobble Bar }\end{array}$ & Edgewater & Glide & $\begin{array}{l}\text { Deep } \\
\text { Water }\end{array}$ & Thalweg \\
\hline \multicolumn{7}{|l|}{$\underline{2004}$} \\
\hline Lower Reach & $76 \%$ & $2 \%$ & $22 \%$ & $0 \%$ & $0 \%$ & $0 \%$ \\
\hline Upper Reach & $81 \%$ & $19 \%$ & $0 \%$ & $0 \%$ & $0 \%$ & $0 \%$ \\
\hline \multicolumn{7}{|l|}{$\underline{2005}$} \\
\hline Lower Reach & $53 \%$ & $20 \%$ & $24 \%$ & $3 \%$ & $0 \%$ & $0 \%$ \\
\hline Upper Reach & $70 \%$ & $0 \%$ & $0 \%$ & $23 \%$ & $5 \%$ & $2 \%$ \\
\hline
\end{tabular}


TABLE 5.-Attachment substrate of egg masses on Coyote Creek in 2004-2005.

\begin{tabular}{cccccc}
\hline & $\begin{array}{c}\text { Stone } \\
\text { Use (\%) }\end{array}$ & $\begin{array}{c}\text { Vegetation/Roots } \\
\text { Use (\%) }\end{array}$ & $\begin{array}{c}\text { Av. Diameter of } \\
\text { Stone (mm) }\end{array}$ & $\begin{array}{c}\text { Gravel } \\
\text { Use (\%) }\end{array}$ & $\begin{array}{c}\text { Cobble } \\
\text { Use (\%) }\end{array}$ \\
\hline$\underline{2004}$ & & & & $83 \%$ & $17 \%$ \\
Lower Reach & $100 \%$ & $0 \%$ & 73 & & \\
Upper Reach & $100 \%$ & $0 \%$ & 43 & $70 \%$ & $30 \%$ \\
$\underline{2005}$ & & $8 \%$ & 71 & & \\
Lower Reach & $92 \%$ & $0 \%$ & 52 & & \\
Upper Reach & $100 \%$ & & & & \\
\hline
\end{tabular}


TABLE 6.-Breeding habitat parameter values measured at egg mass locations along Coyote Creek in 2004-2005.

\begin{tabular}{|c|c|c|c|}
\hline & Mean/Total (n) & SE & Range \\
\hline \multicolumn{4}{|l|}{$\underline{\underline{2004}}$} \\
\hline \multicolumn{4}{|l|}{ Lower Reach } \\
\hline Distance from shore $(\mathrm{m})$ & $2.23(41)$ & 0.212 & $0.610-6.08$ \\
\hline Water Temperature $\left({ }^{\circ} \mathrm{C}\right)$ & no data & no data & no data \\
\hline Canopy coverage (\%) & $27 \%(41)$ & 3.666 & $2 \%-96 \%$ \\
\hline Egg mass diameter (mm) & $57(5)$ & 5.418 & $38-70$ \\
\hline Water depth at egg mass (m) & $0.131(41)$ & 0.009 & $0.60-0.320$ \\
\hline \multicolumn{4}{|l|}{ Upper Reach } \\
\hline Distance from shore (m) & $3.178(31)$ & 0.16 & $0.78-4.53$ \\
\hline Water Temperature $\left({ }^{\circ} \mathrm{C}\right)$ & no data & no data & no data \\
\hline Canopy coverage (\%) & $32 \%(31)$ & 3.586 & $5 \%-85 \%$ \\
\hline Egg mass diameter (mm) & $51.4(29)$ & 2.441 & $38-79$ \\
\hline Water depth at egg mass (m) & $0.191(31)$ & 0.013 & $0.08-0.46$ \\
\hline \multicolumn{4}{|l|}{$\underline{2005}$} \\
\hline \multicolumn{4}{|l|}{ Lower Reach } \\
\hline Distance from shore (m) & $1.91(59)$ & 0.178 & $0.100-6.52$ \\
\hline Water Temperature $\left({ }^{\circ} \mathrm{C}\right)$ & $14.9(59)$ & 0.215 & $12.5-19.3$ \\
\hline Canopy coverage (\%) & $31 \%(59)$ & 3.011 & $2 \%-96 \%$ \\
\hline Egg mass diameter $(\mathrm{mm})$ & $43(59)$ & 2.046 & $16-83$ \\
\hline Water depth at egg mass (m) & $0.237(59)$ & 0.027 & $0.06-1.14$ \\
\hline \multicolumn{4}{|l|}{ Upper Reach } \\
\hline Distance from shore (m) & $2.59(44)$ & 0.182 & $0.27-5.61$ \\
\hline Water Temperature $\left({ }^{\circ} \mathrm{C}\right)$ & $14.3(44)$ & 0.297 & 11.3-19.1 \\
\hline Canopy coverage (\%) & $18 \%(44)$ & 1.41 & $6 \%-48 \%$ \\
\hline Egg mass diameter (mm) & $46(44)$ & 2.196 & $19-76$ \\
\hline Water depth at egg mass (m) & $0.238(44)$ & 0.035 & $0.10-1.66$ \\
\hline
\end{tabular}


TABLE 7.- Juvenile frogs marked and recaptured from 2004 to 2005.

\begin{tabular}{|c|c|c|c|c|c|}
\hline & $\begin{array}{l}\text { Number } \\
\text { Marked }\end{array}$ & $\begin{array}{c}\text { Recaptured } \\
\text { Once }(\%)\end{array}$ & $\begin{array}{l}\text { Recaptured } \\
\text { Two or More } \\
\text { Times (\%) } \\
\end{array}$ & $\begin{array}{c}\text { Number } \\
\text { Recaptured as } \\
\text { Adult Females } \\
\end{array}$ & $\begin{array}{c}\text { Number } \\
\text { Recaptured as } \\
\text { Adult Males } \\
\end{array}$ \\
\hline \multicolumn{6}{|l|}{2004} \\
\hline Lower & 14 & 29 & 14 & 2 & 1 \\
\hline Middle & 0 & 0 & 0 & 0 & 0 \\
\hline Upper & 25 & 32 & 12 & 0 & 3 \\
\hline Dexter Creek & 0 & 0 & 0 & 0 & 0 \\
\hline \multicolumn{6}{|l|}{ Sheep Ridge } \\
\hline Creek & 0 & 0 & 0 & 0 & 0 \\
\hline $\begin{array}{l}\text { Total } \\
2005\end{array}$ & 39 & 31 & 13 & 2 & 1 \\
\hline Lower & 11 & 73 & 36 & 1 & 3 \\
\hline Middle & 0 & 0 & 0 & 0 & 0 \\
\hline Upper & 2 & 100 & 50 & 0 & 2 \\
\hline Dexter Creek & 4 & 75 & 50 & 1 & 0 \\
\hline \multicolumn{6}{|l|}{ Sheep Ridge } \\
\hline Creek & 2 & 50 & 0 & 0 & 0 \\
\hline Total & 19 & 74 & 37 & 2 & 5 \\
\hline
\end{tabular}

TABLE 8.- Size ranges of adult foothill yellow-legged frogs captured within the study area during 2004-2005.

\begin{tabular}{|c|c|c|c|c|c|c|}
\hline \multirow[b]{2}{*}{2004} & \multicolumn{3}{|c|}{ Females } & \multicolumn{3}{|c|}{ Males } \\
\hline & $\mathrm{N}$ & Weight (g) & $\mathrm{SVL}(\mathrm{mm})$ & $\mathrm{N}$ & Weight (g) & $\mathrm{SVL}(\mathrm{mm})$ \\
\hline Lower & 1 & 7.5 & 42 & 2 & $9.8-11.0$ & $41-47$ \\
\hline Middle & 1 & 7.5 & 40 & 0 & $\mathrm{n} / \mathrm{a}$ & $\mathrm{n} / \mathrm{a}$ \\
\hline Upper & 9 & $9.0-37.0$ & $45-71$ & 11 & $6.5-16.3$ & $40-55$ \\
\hline Dexter Creek & 7 & $11.2-45.0$ & $41-72$ & 1 & 20.5 & 57 \\
\hline Sheep Ridge Creek & 0 & $\mathrm{n} / \mathrm{a}$ & $\mathrm{n} / \mathrm{a}$ & 0 & $\mathrm{n} / \mathrm{a}$ & $\mathrm{n} / \mathrm{a}$ \\
\hline Total & 18 & $7.5-45.0$ & $40-72$ & 14 & $6.5-20.5$ & $40-57$ \\
\hline \multicolumn{7}{|l|}{2005} \\
\hline Lower & 4 & $7.5-43.5$ & $41-71$ & 20 & $8.0-26.0$ & $40-58$ \\
\hline Middle & 0 & $\mathrm{n} / \mathrm{a}$ & $\mathrm{n} / \mathrm{a}$ & 0 & $\mathrm{n} / \mathrm{a}$ & $\mathrm{n} / \mathrm{a}$ \\
\hline Upper & 7 & $8.5-32.5$ & $42-63$ & 9 & $8.5-18.0$ & $41-54$ \\
\hline Dexter Creek & 20 & $7.5-48$ & $40-74$ & 25 & $9.0-25.0$ & $41-59$ \\
\hline Sheep Ridge Creek & 2 & $11.0-28.5$ & $46-57$ & 1 & 8.5 & 42 \\
\hline Total & 33 & $7.5-48.0$ & $40-74$ & 55 & $8.0-26.0$ & $41-59$ \\
\hline
\end{tabular}


TABLE 9.- Number of males and females captured and sex ratios at the lower and upper reaches in 2005 and summer residence locations between lower main stem and Dexter Creek in 2004 and 2005.

2005

Lower Reach

40

27

1.48
Upper Reach

13

7

1.85

Ratio (males/females)

Residence locations for adults in the lower reach.

Mainstem (Lower Reach)

(n) $\%$

Males

2004

2005

Females

2004

2005
(2) $66 \%$

(16) $36 \%$

(1) $13 \%$

(3) $13 \%$
Dexter Creek

(n) $\%$

(1) $33 \%$

(26) $64 \%$

(7) $87 \%$

(20) $87 \%$

TABLE 10.-Detectability of non-radiotagged stationary adult foothill yellow-legged frogs on Dexter Creek concurrent with radiotracking.

\begin{tabular}{ccccc}
\hline Frog I.D & Sex & $\begin{array}{c}\text { Number of } \\
\text { radiotracking surveys }\end{array}$ & Number of detections & Detectability \\
\hline K84 & Male & 18 & 3 & $17 \%$ \\
K91 & Female & 7 & 4 & $57 \%$ \\
L44 & Female & 12 & 8 & $67 \%$ \\
L48 & Female & 26 & 3 & $12 \%$ \\
L49 & Male & 15 & 7 & $47 \%$ \\
L57 & Male & 19 & 4 & $21 \%$ \\
L64 & Male & 12 & 5 & $42 \%$ \\
L73 & Male & 8 & 3 & $38 \%$ \\
Total/Mean & & 117 & 37 & $32 \%$ \\
\hline
\end{tabular}


TABLE 11.-Mesohabitat physical parameter values by reach for the Coyote Creek study area.

\begin{tabular}{|c|c|c|c|c|c|}
\hline Physical Habitat Parameters & Length $(\mathrm{m})$ & Mean Width (m) & Mean Depth (m) & Mean Maximum Depth (m) & Mean Canopy (\%) \\
\hline \multicolumn{6}{|l|}{ Mainstem Lower Reach } \\
\hline Pool & 1788 & 7.01 & 0.27 & 0.76 & 17 \\
\hline Turbulent & 374 & 4.88 & 0.08 & 0.14 & 24 \\
\hline Flatwater & 216 & 3.05 & 0.11 & 0.21 & 21 \\
\hline Total Reach & 2377 & 5.79 & 0.18 & 0.46 & 20 \\
\hline \multicolumn{6}{|l|}{$\underline{\text { Mainstem Middle Reach }}$} \\
\hline Pool & 2150 & 7.62 & 0.40 & 0.95 & 15 \\
\hline Turbulent & 973 & 4.57 & 0.08 & 0.15 & 20 \\
\hline Flatwater & 636 & 3.96 & 0.10 & 0.21 & 16 \\
\hline Total Reach & 3704 & 5.79 & 0.22 & 0.51 & 17 \\
\hline \multicolumn{6}{|l|}{ Mainstem Upper Reach } \\
\hline Pool & 1991 & 5.79 & 0.34 & 0.67 & 41 \\
\hline Turbulent & 273 & 4.27 & 0.08 & 0.15 & 55 \\
\hline Flatwater & 195 & 4.27 & 0.11 & 0.22 & 44 \\
\hline Total Reach & 2459 & 5.18 & 0.22 & 0.44 & 46 \\
\hline \multicolumn{6}{|l|}{$\underline{\text { Dexter Creek }}$} \\
\hline Pool & 1057 & 2.04 & 0.23 & 0.41 & 91 \\
\hline Turbulent & 754 & 2.44 & 0.09 & 0.16 & 91 \\
\hline Flatwater & 329 & 2.13 & 0.08 & 0.18 & 91 \\
\hline Total Reach & 2140 & 2.20 & 0.16 & 0.29 & 91 \\
\hline
\end{tabular}


TABLE 12.-Dominant and sub-dominant substrate by reach for the Coyote Creek study area.

\begin{tabular}{ccccc}
\hline & Sand & Gravel & Cobble & Boulder \\
\cline { 2 - 5 } Lower Reach & & & & \\
Dominant & $9 \%$ & $41 \%$ & $43 \%$ & $7 \%$ \\
Sub-Dominant & $12 \%$ & $38 \%$ & $32 \%$ & $18 \%$ \\
\hline Middle Reach & & & & \\
Dominant & $1 \%$ & $34 \%$ & $64 \%$ & $1 \%$ \\
Sub-Dominant & $12 \%$ & $35 \%$ & $20 \%$ & $33 \%$ \\
\hline Upper Reach & & & & \\
Dominant & $28 \%$ & $40 \%$ & $31 \%$ & $1 \%$ \\
Sub-Dominant & $3 \%$ & $23 \%$ & $46 \%$ & $28 \%$ \\
\hline Dexter Creek & & & & \\
Dominant & $0 \%$ & $24 \%$ & $23 \%$ & $53 \%$ \\
Sub-Dominant & $1 \%$ & $13 \%$ & $48 \%$ & $38 \%$ \\
\hline
\end{tabular}


TABLE 13.-Escape cover availability by reach for adult foothill yellow-legged frogs in the Coyote Creek study area.

\begin{tabular}{|c|c|c|c|c|c|c|c|c|c|c|}
\hline & $\begin{array}{c}\text { Av. number } \\
\text { of Cover } \\
\text { Types }\end{array}$ & Substrate & $\begin{array}{c}\text { Surface } \\
\text { Turbulence }\end{array}$ & Depth & $\begin{array}{c}\text { Undercut } \\
\text { Banks }\end{array}$ & Rootwad & Wood & Trees & Grass/Sedge & $\begin{array}{c}\text { Aquatic } \\
\text { Vegetation }\end{array}$ \\
\hline \multicolumn{11}{|l|}{ Lower Reach } \\
\hline$\overline{\text { All Habitats }}$ & 3.4 & $98 \%$ & $45 \%$ & $26 \%$ & $10 \%$ & $10 \%$ & $7 \%$ & $60 \%$ & $5 \%$ & $83 \%$ \\
\hline Flatwater & 2.75 & $100 \%$ & $25 \%$ & $0 \%$ & $0 \%$ & $0 \%$ & $0 \%$ & $75 \%$ & $0 \%$ & $75 \%$ \\
\hline Pool & 3.71 & $95 \%$ & $5 \%$ & $52 \%$ & $19 \%$ & $19 \%$ & $14 \%$ & $76 \%$ & $5 \%$ & $86 \%$ \\
\hline Turbulent & 3.18 & $100 \%$ & $100 \%$ & $0 \%$ & $0 \%$ & $0 \%$ & $0 \%$ & $35 \%$ & $6 \%$ & $82 \%$ \\
\hline \multicolumn{11}{|l|}{ Middle Reach } \\
\hline All Habitats & 2.6 & $99 \%$ & $38 \%$ & $20 \%$ & $3 \%$ & $24 \%$ & $7 \%$ & $13 \%$ & $1 \%$ & $50 \%$ \\
\hline Flatwater & 1.9 & $100 \%$ & $21 \%$ & $0 \%$ & $0 \%$ & $7 \%$ & $0 \%$ & $14 \%$ & $0 \%$ & $50 \%$ \\
\hline Pool & 2.9 & $97 \%$ & $0 \%$ & $44 \%$ & $6 \%$ & $44 \%$ & $15 \%$ & $24 \%$ & $3 \%$ & $56 \%$ \\
\hline Turbulent & 2.43 & $100 \%$ & $93 \%$ & $0 \%$ & $0 \%$ & $7 \%$ & $0 \%$ & $0 \%$ & $0 \%$ & $43 \%$ \\
\hline \multicolumn{11}{|l|}{ Upper Reach } \\
\hline All Habitats & 3.4 & $100 \%$ & $45 \%$ & $23 \%$ & $3 \%$ & $0 \%$ & $2 \%$ & $64 \%$ & $63 \%$ & $24 \%$ \\
\hline Flatwater & 2.9 & $100 \%$ & $50 \%$ & $0 \%$ & $0 \%$ & $0 \%$ & $0 \%$ & $5 \%$ & $4 \%$ & $2 \%$ \\
\hline Pool & 3.8 & $100 \%$ & $47 \%$ & $44 \%$ & $6 \%$ & $0 \%$ & $3 \%$ & $94 \%$ & $97 \%$ & $94 \%$ \\
\hline Turbulent & 3.1 & $100 \%$ & $100 \%$ & $0 \%$ & $0 \%$ & $0 \%$ & $0 \%$ & $64 \%$ & $50 \%$ & $18 \%$ \\
\hline \multicolumn{11}{|l|}{ Dexter Creek } \\
\hline All Habitats & 2.4 & $99 \%$ & $73 \%$ & $47 \%$ & $9 \%$ & $2 \%$ & $1 \%$ & $5 \%$ & $0 \%$ & $0 \%$ \\
\hline Flatwater & 1.8 & $100 \%$ & $73 \%$ & $3 \%$ & $0 \%$ & $0 \%$ & $0 \%$ & $0 \%$ & $0 \%$ & $0 \%$ \\
\hline Pool & 2.8 & $99 \%$ & $59 \%$ & $87 \%$ & $16 \%$ & $4 \%$ & $2 \%$ & $8 \%$ & $0 \%$ & $1 \%$ \\
\hline Turbulent & 2.04 & $100 \%$ & $94 \%$ & $6 \%$ & $1 \%$ & $0 \%$ & $1 \%$ & $2 \%$ & $0 \%$ & $0 \%$ \\
\hline
\end{tabular}


TABLE 14.- Adult foothill yellow-legged frog mesohabitat availability and use during summer/fall in the Coyote Creek study area. Total observations includes, frogs not captured and sexed.

\begin{tabular}{ccccc}
\hline & Pool & Turbulent & Flatwater & Totals \\
\hline Mainstem Coyote Creek & & & & \\
Males (n=74) & $72 \%$ & $19 \%$ & $9 \%$ & 74 \\
Females (n=34) & $62 \%$ & $18 \%$ & $20 \%$ & 34 \\
Total Observations (n=303) & $72 \%$ & $18 \%$ & $10 \%$ & 303 \\
Available & $52 \%$ & $37 \%$ & $11 \%$ & 106 \\
\hline & & & & \\
Dexter Creek & & & & \\
Males (n=194) & $98 \%$ & $2 \%$ & $0 \%$ & 194 \\
Females (n=236) & $97 \%$ & $2 \%$ & $1 \%$ & 236 \\
Total Observations (n=613) & $97 \%$ & $2 \%$ & $1 \%$ & 613 \\
Available & $52 \%$ & $38 \%$ & $10 \%$ & 317 \\
\hline
\end{tabular}

TABLE 15.-Dominant substrate mesohabitat availability and use by adult foothill yellow-legged frogs, in the Coyote Creek study area.

\begin{tabular}{cccccc}
\hline & Sand & Gravel & Cobble & Boulder & Bedrock \\
\hline Mainstem Coyote Creek & & & & & \\
Males (n=74) & $0 \%$ & $43 \%$ & $31 \%$ & $26 \%$ & $0 \%$ \\
Females (n=34) & $0 \%$ & $31 \%$ & $19 \%$ & $50 \%$ & $0 \%$ \\
Total Observations (n=303) & $2 \%$ & $38 \%$ & $27 \%$ & $32 \%$ & $0 \%$ \\
Available & $20 \%$ & $40 \%$ & $36 \%$ & $4 \%$ & $0 \%$ \\
\hline Dexter Creek & & & & & \\
Males (n=194) & & & & & \\
Females (n=236) & $0 \%$ & $34 \%$ & $3 \%$ & $63 \%$ & $0 \%$ \\
Total Observations (n=613) & $0 \%$ & $24 \%$ & $6 \%$ & $70 \%$ & $0 \%$ \\
Available & $0 \%$ & $29 \%$ & $6 \%$ & $65 \%$ & $0 \%$ \\
\hline
\end{tabular}


TABLE 16.-Depth, canopy and cover complexity of mesohabitats available and used by adult foothill yellow-legged frogs in the Coyote Creek study area.

\begin{tabular}{cccc}
\hline & $\begin{array}{c}\text { Mean Maximum } \\
\text { Depth }(\mathrm{m})\end{array}$ & $\begin{array}{c}\text { Mean Canopy Coverage } \\
\%\end{array}$ & $\begin{array}{c}\text { Mean Number of Cover } \\
\text { Types }\end{array}$ \\
\hline $\begin{array}{c}\text { Mainstem Coyote } \\
\text { Creek }\end{array}$ & & & \\
Males (n=74) & 0.68 & $33 \%$ & 3.4 \\
Females ( $=34)$ & 0.63 & $43 \%$ & 4.3 \\
Total Observations & & & \\
$\quad(\mathrm{n}=303)$ & 0.75 & $41 \%$ & 3.5 \\
Available & 0.45 & $36 \%$ & 3.4 \\
\hline Dexter Creek & & & 3.7 \\
\hline Males (n=194) & 0.37 & $87 \%$ & 3.8 \\
Females (n=236) & 0.46 & $85 \%$ & 3.6 \\
Total Observations & & & \\
$(\mathrm{n}=613)$ & 0.40 & $85 \%$ & 2.4 \\
Available & 0.25 & $91 \%$ & \\
\hline
\end{tabular}




\section{APPENDIX A - PROJECT PHOTOS}




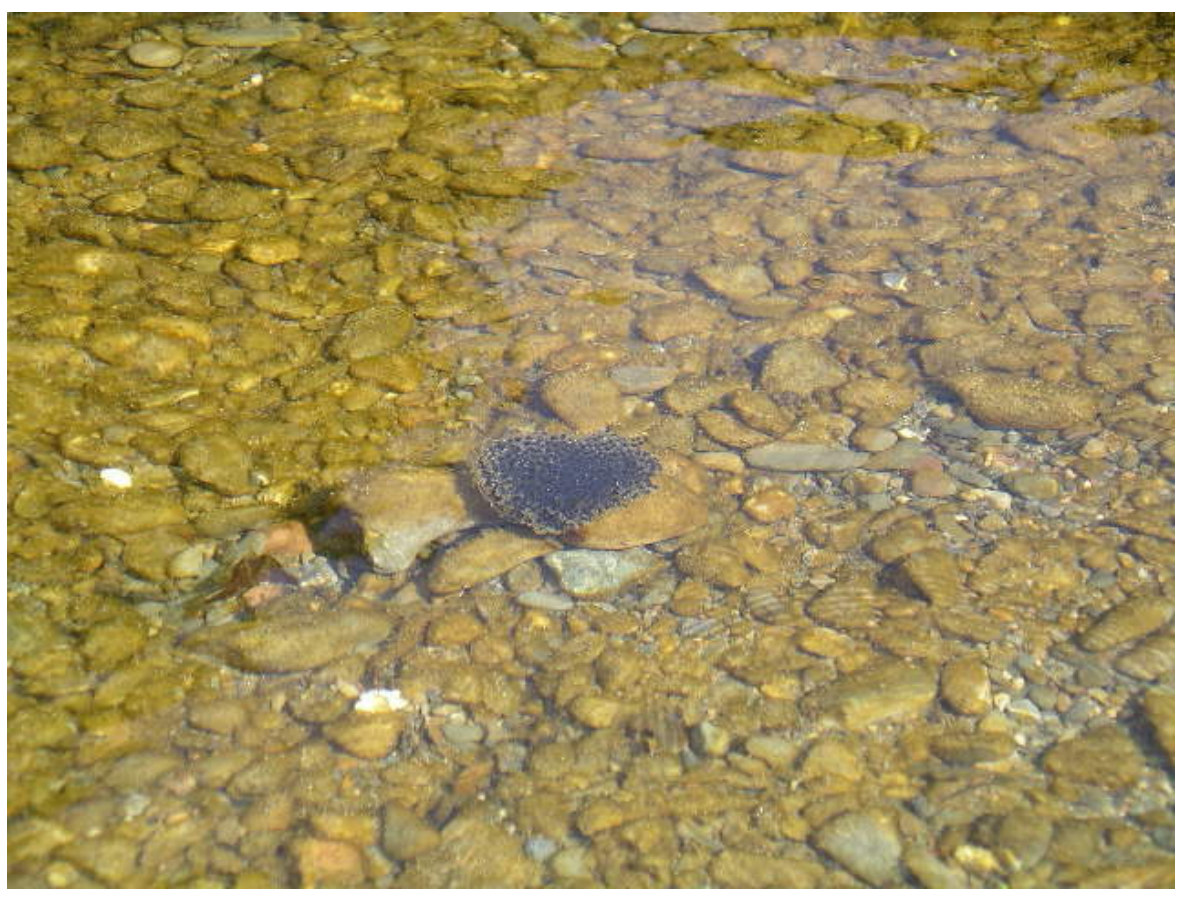

Рното 1.- A large two day old egg mass deposited in shallow, slow water and attached to small cobble substrate.

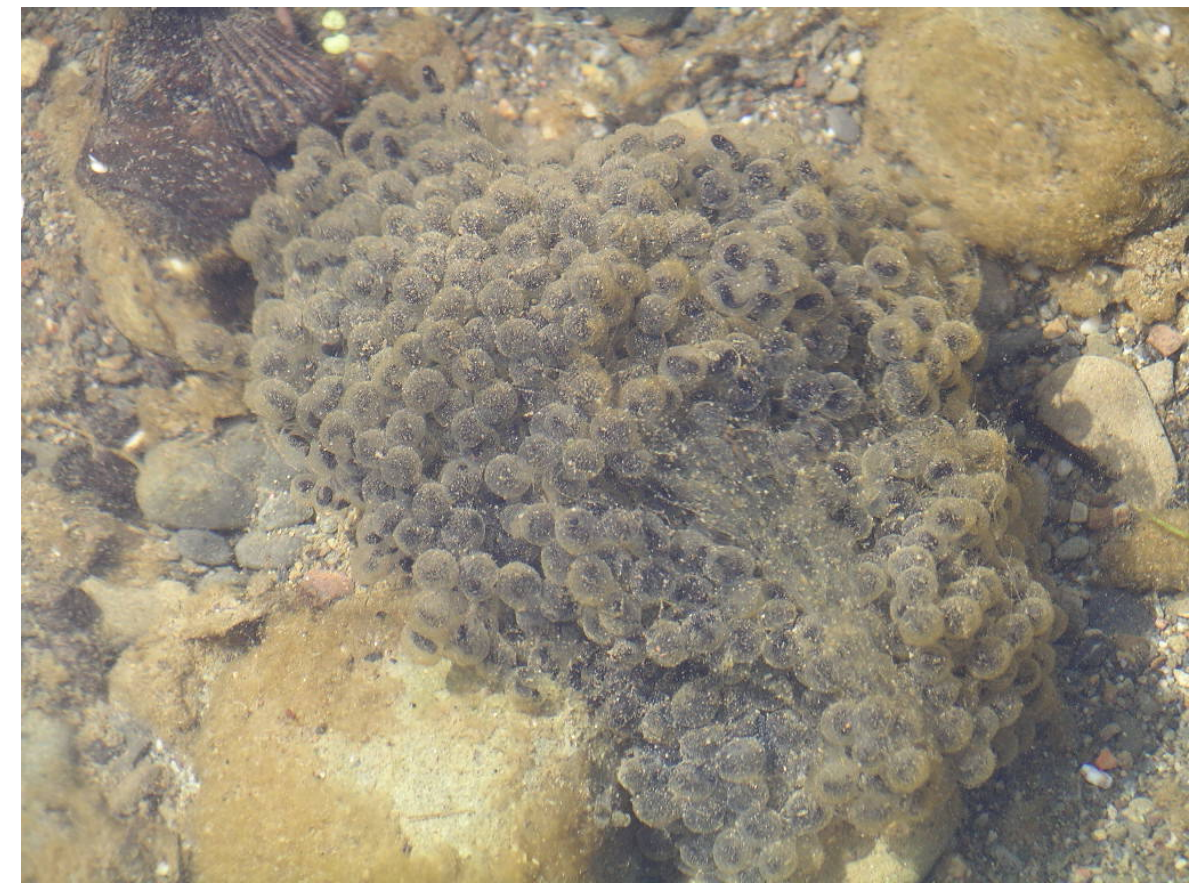

Рното 2.- This ten day old egg mass was in advanced development and covered with a film of silt and algae. 


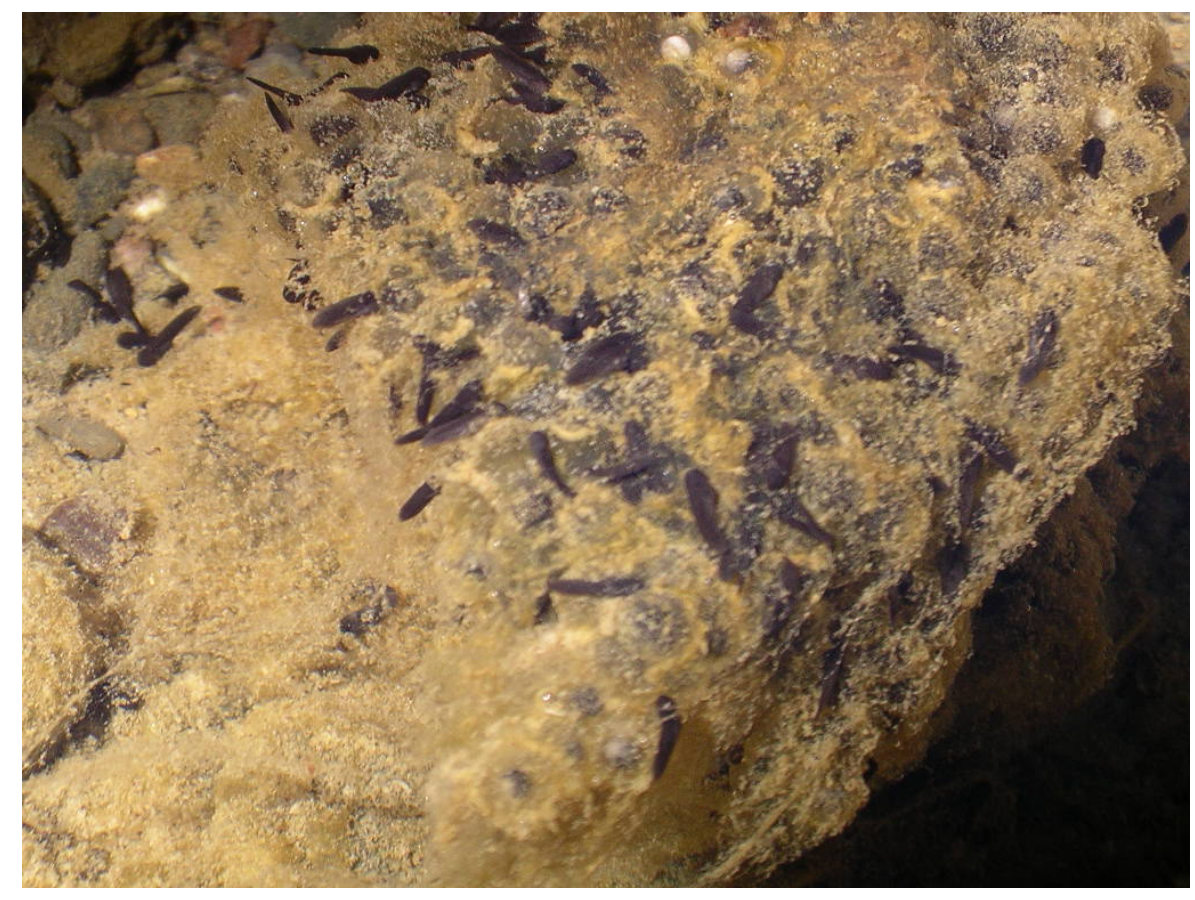

Рното 3.- Tadpoles started to hatch less than twenty four hours prior to this photo, and some are still un-hatched.

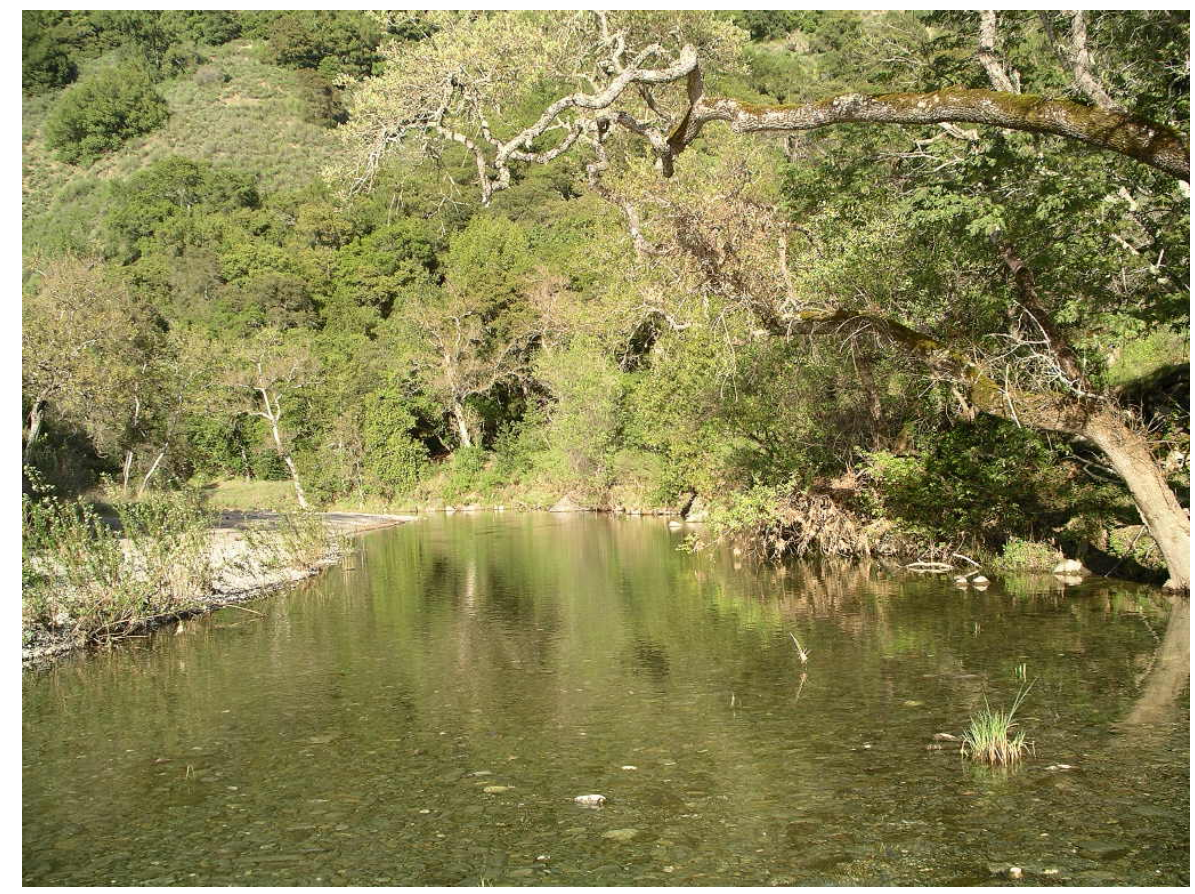

Рното 4. - A typical foothill yellow-legged frog breeding habitat that is wide, shallow and with slow water and gravel/cobble substrate. Note the cobble bar on the bank at left. 


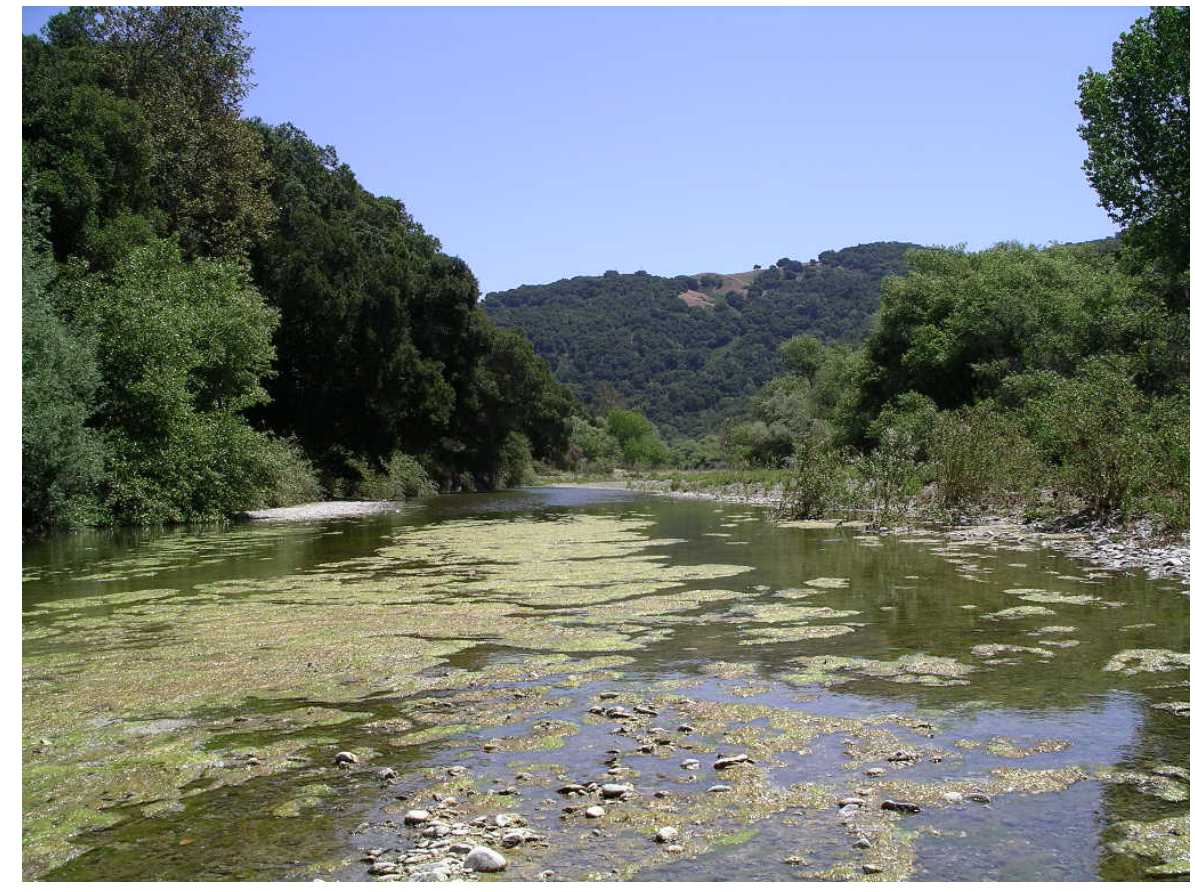

Рното 5.- A typical pool on the lower reach with a wide, shallow and glide-like tail of pool with an open canopy.

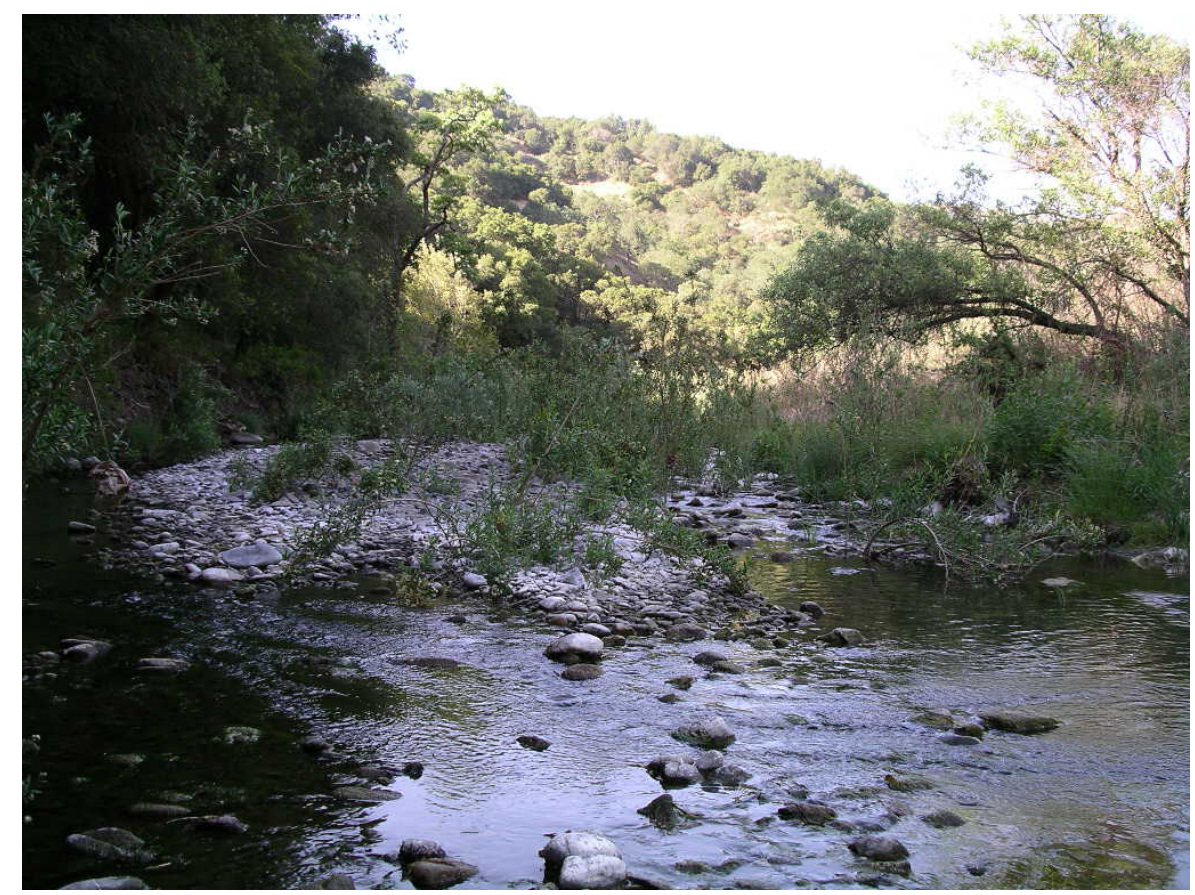

Pното 6.- A cobble and boulder-dominated riffle on the lower reach with an open canopy. 


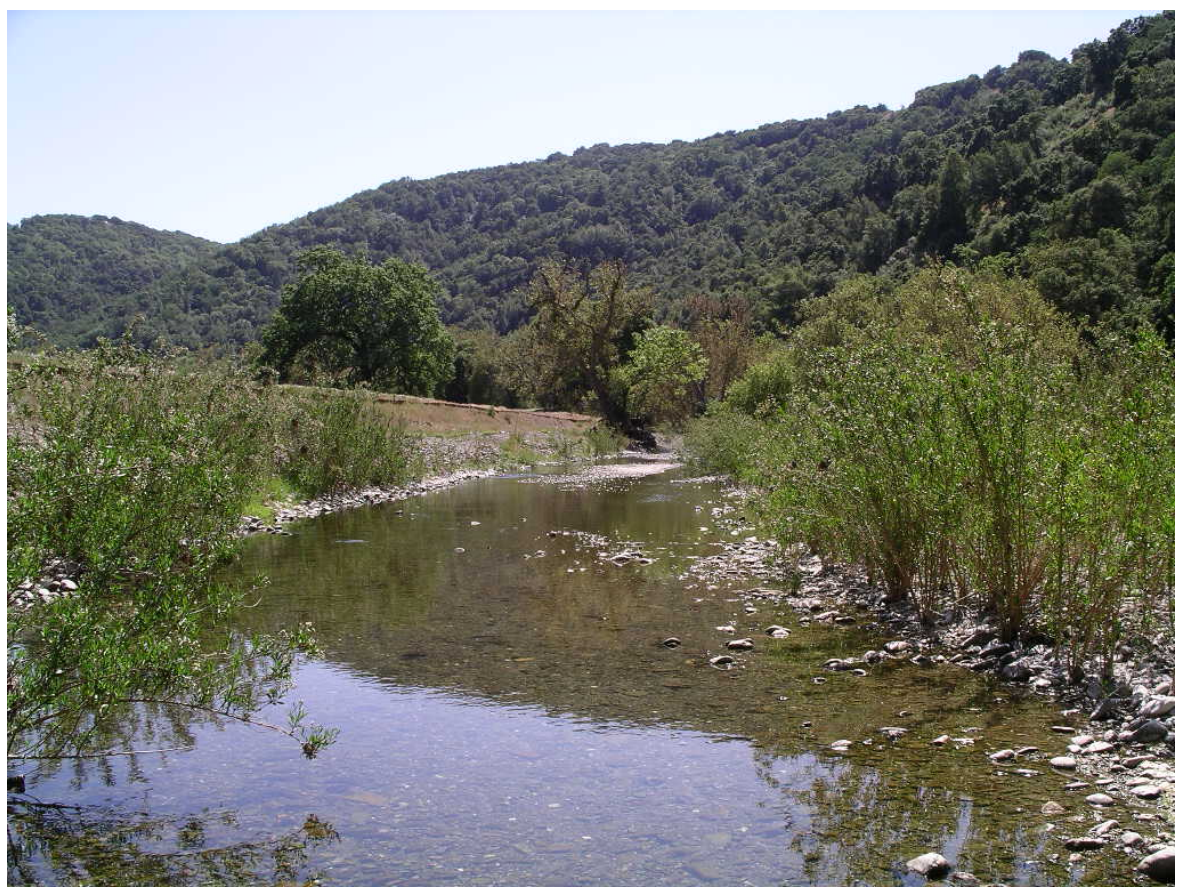

Рното 7.- A typical large pool on the middle reach that is gravel and cobble dominated and with almost no canopy.

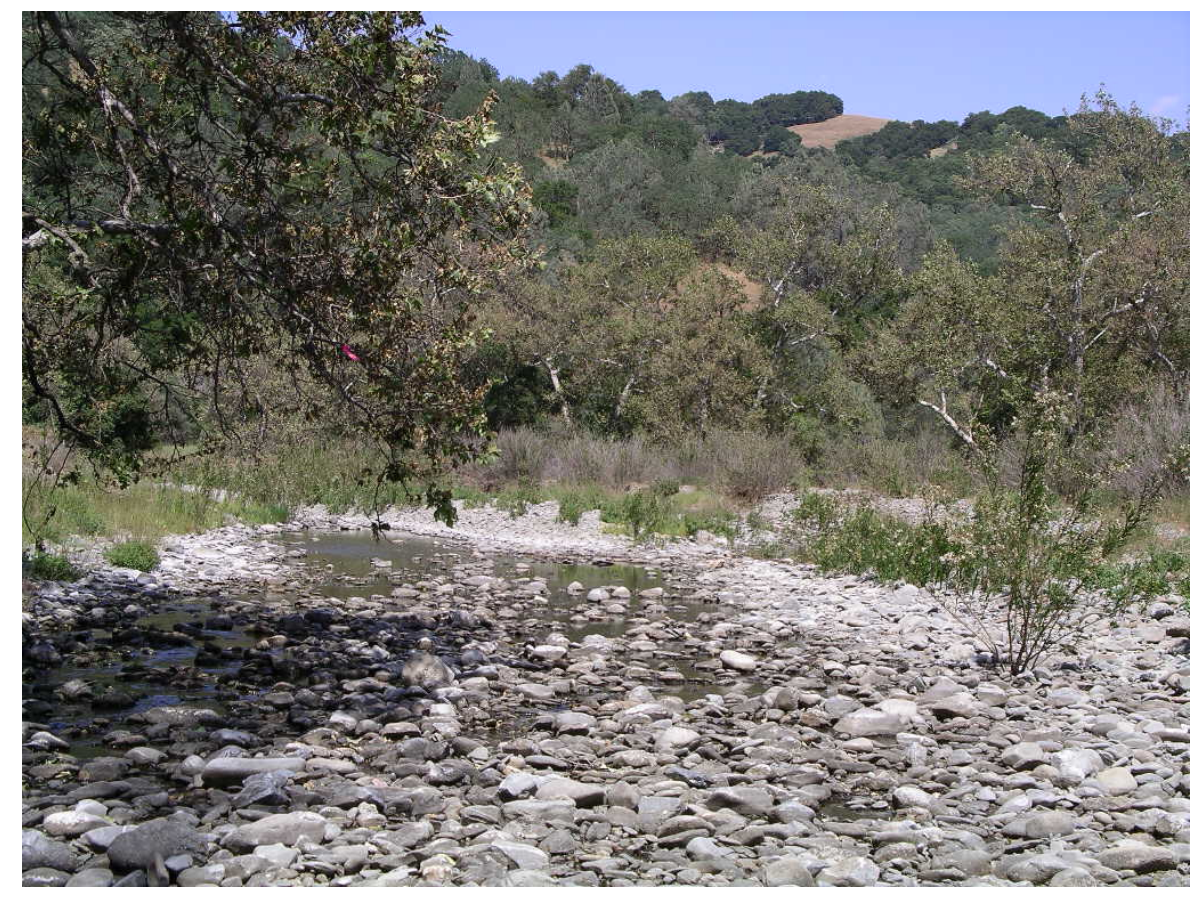

Рното 8.- A typical open-canopied riffle on the middle reach that is mostly dry in late spring, 2004. 


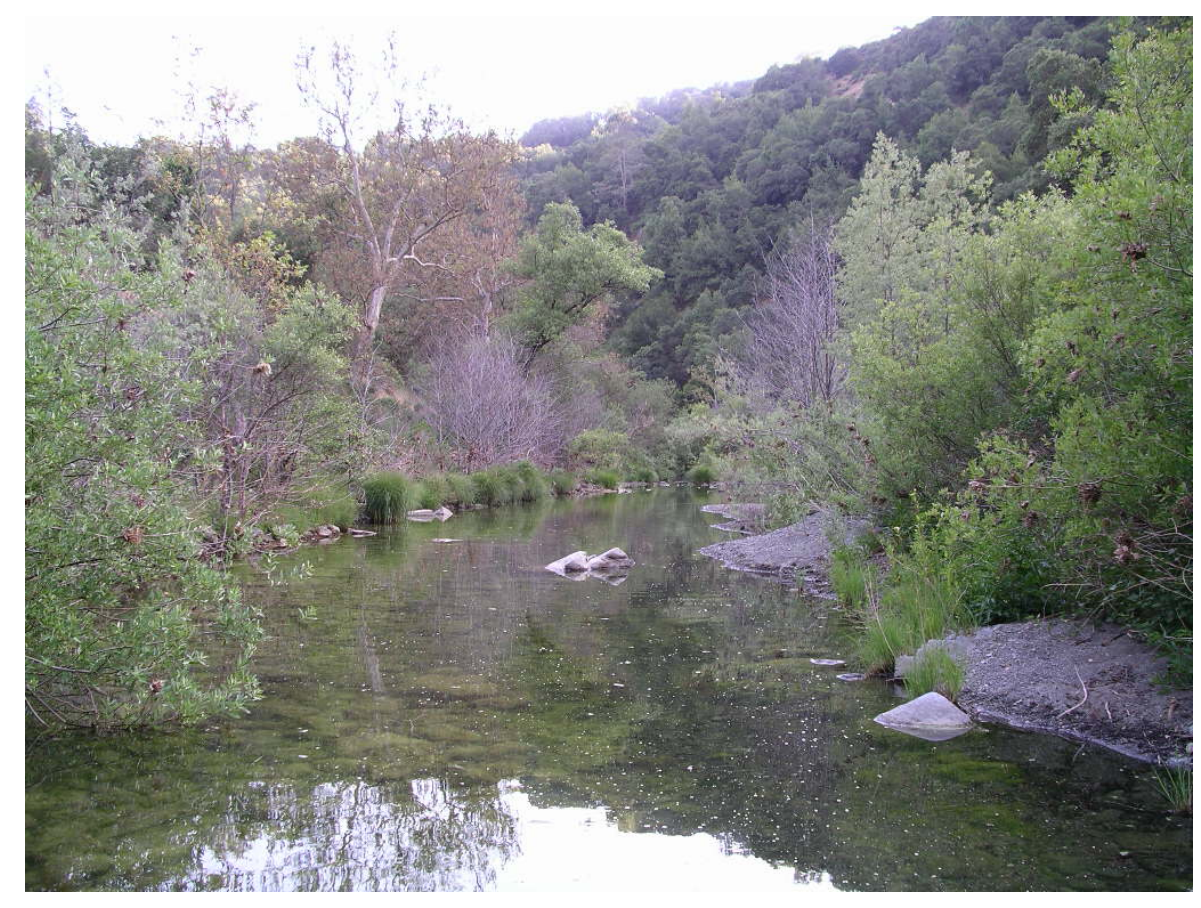

Рното 9.- The most prolific breeding habitat on the upper reach (upper breeding site) that has open canopy, gravel/cobble dominated substrate, and reliable water through early summer.

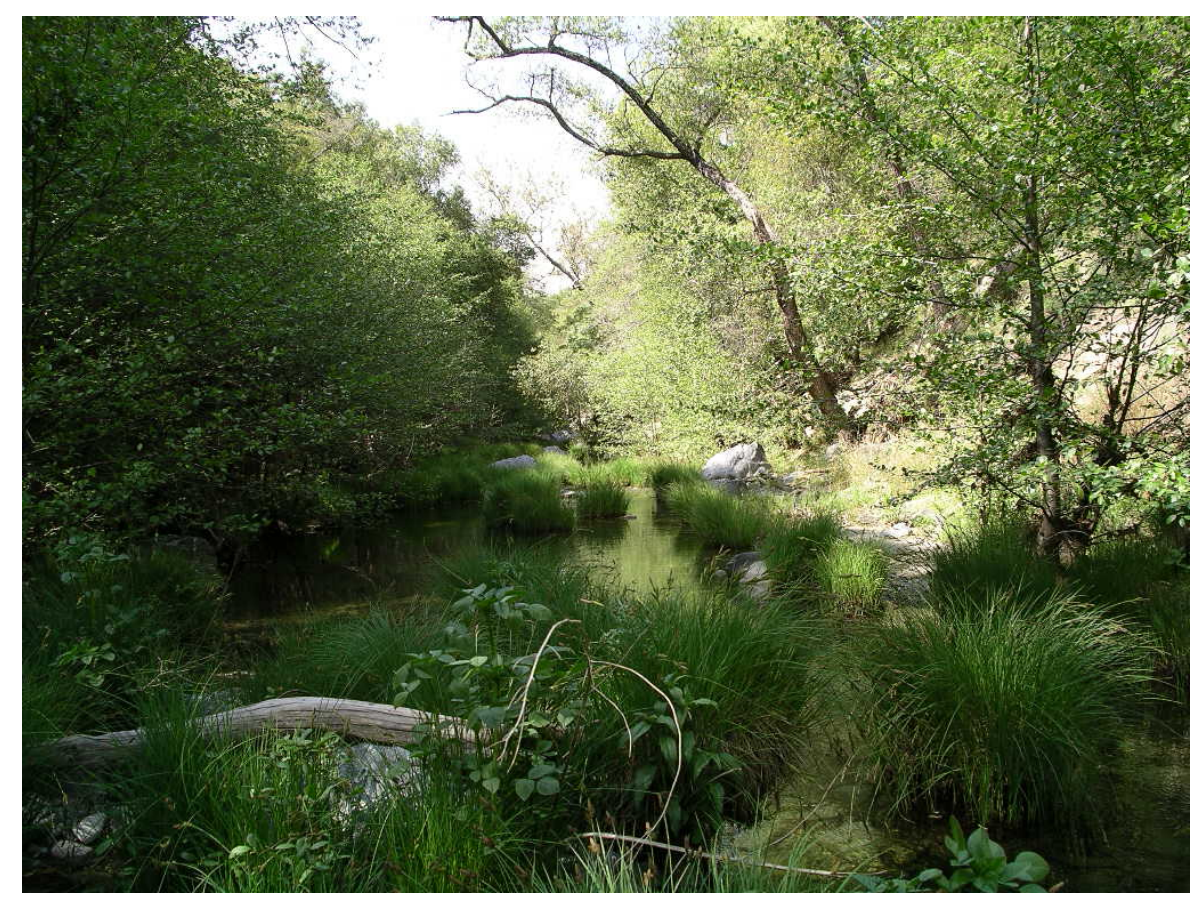

Рното 10.--Perennial run habitat on the upper reach with an abundance of instream escape cover and with moderate canopy cover. 


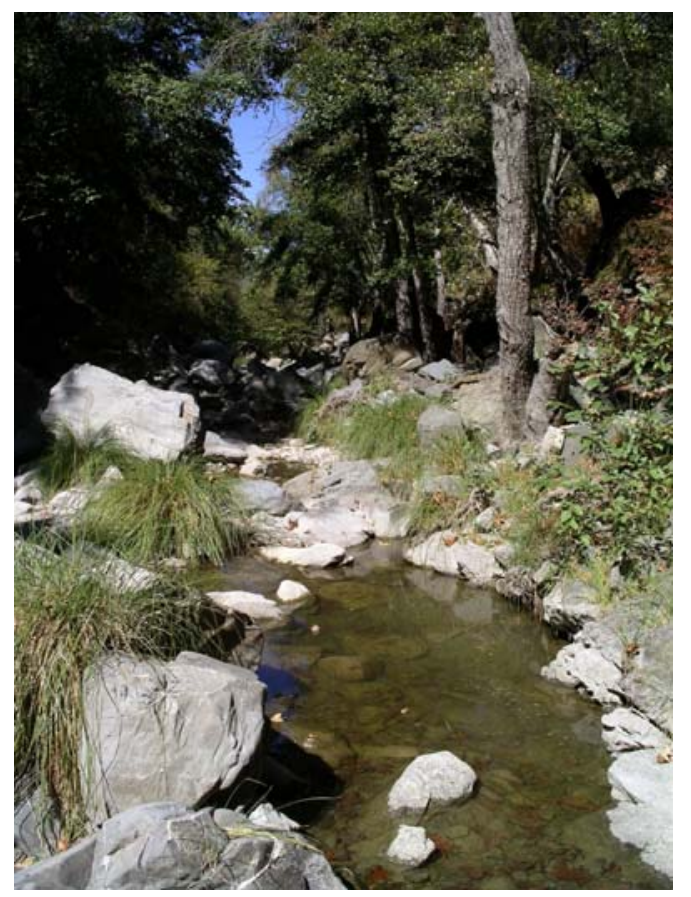

Рното 11.-A small boulder-dominated perennial pool on the upper reach with moderate canopy and reliable escape cover from predators.

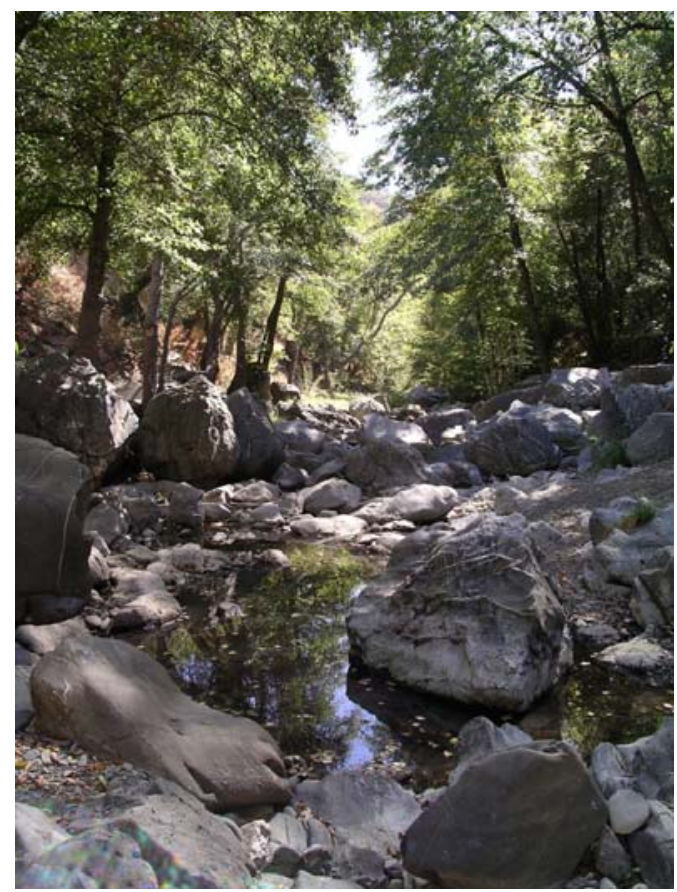

Рното 12.- Remnants of a pool on the upper reach that provided rearing habitat for young of the year frogs during fall, 2004. 


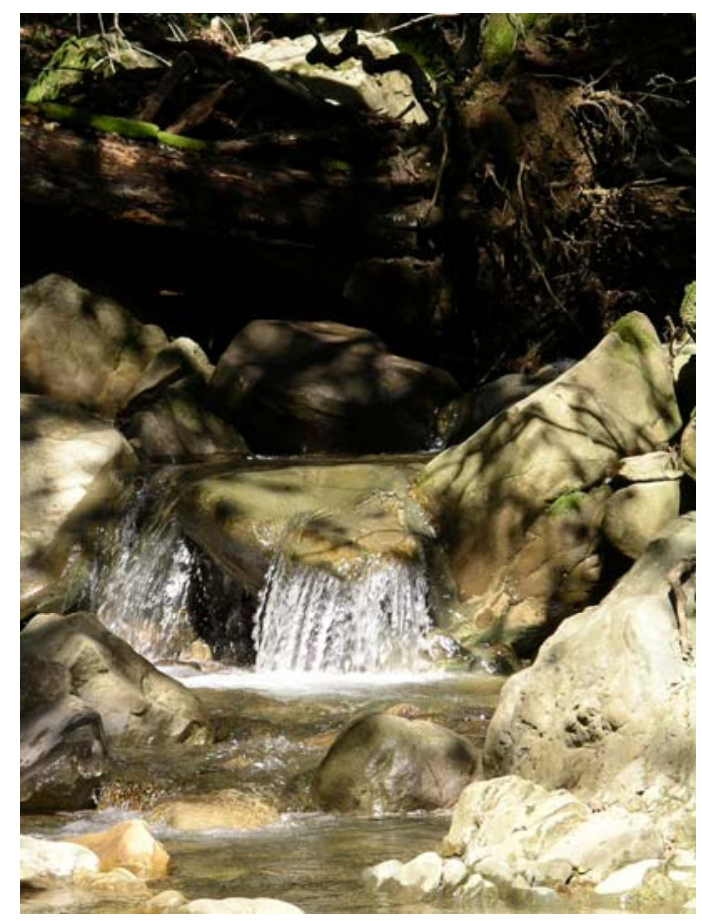

Рното 13.- A typical small plunge pool habitat alternated with short cascades and riffles on Dexter Creek.

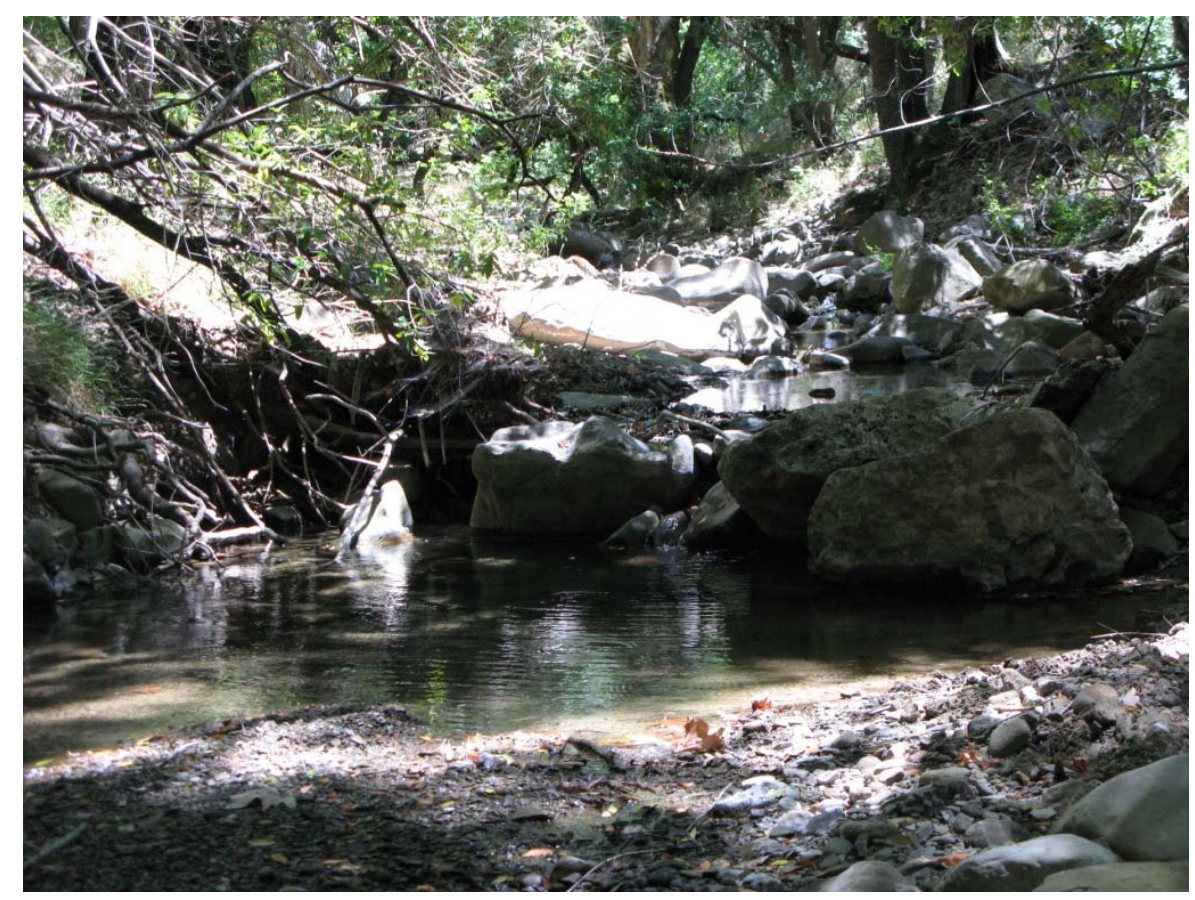

Рното 14.-A relatively large perennial pool on Dexter Creek near its confluence with main stem Coyote Creek. 


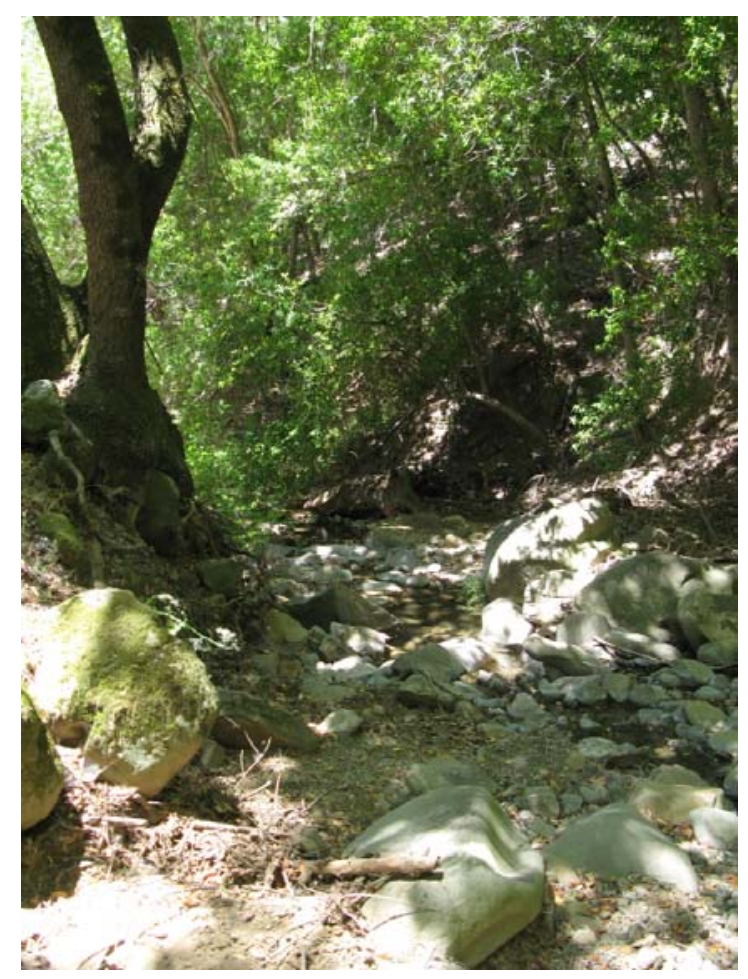

Рното 15.- An intermittent step run sequence on Dexter Creek.

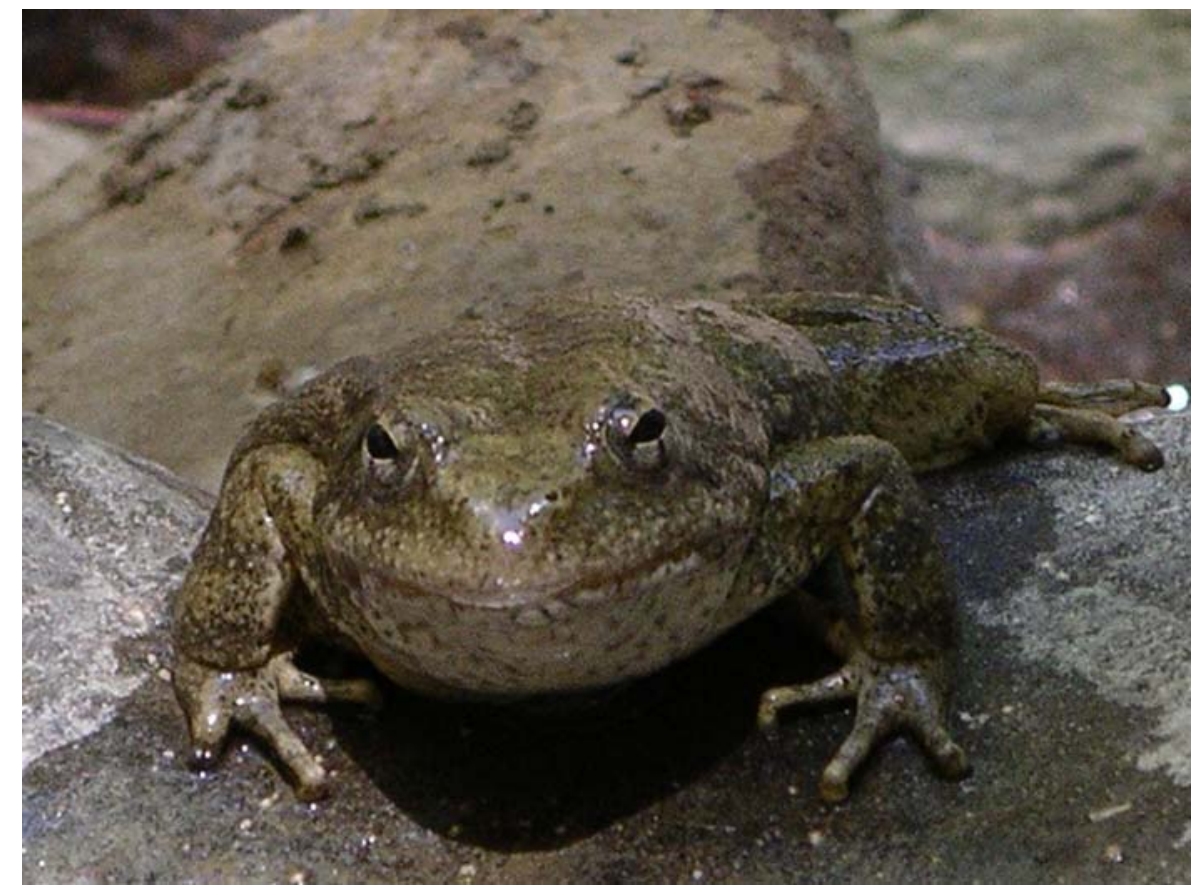

Рното 16.-A very large female foothill yellow-legged frog that had its transmitter removed prior to this photo. 


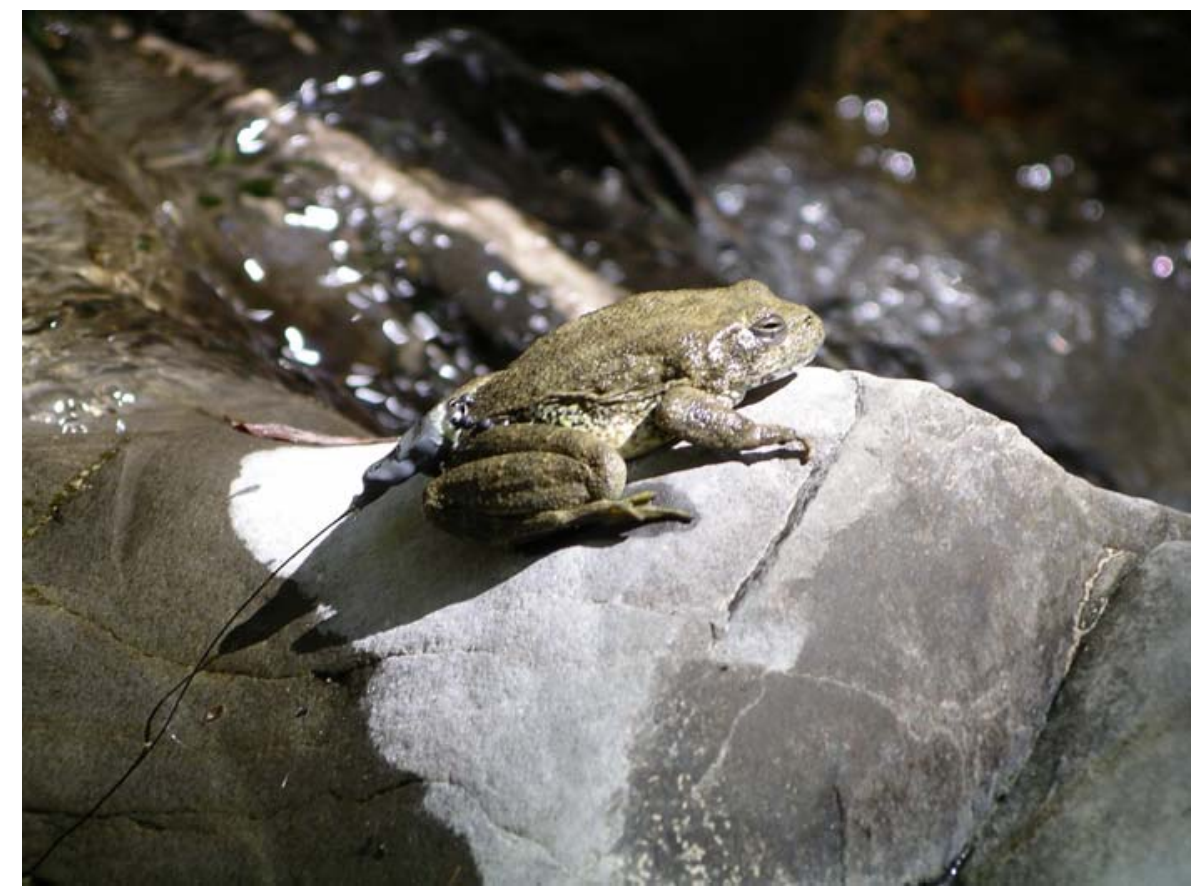

Рното 17.- A basking radiotagged frog on Dexter Creek. The frog is utilizing a sun fleck at the head of a plunge pool.

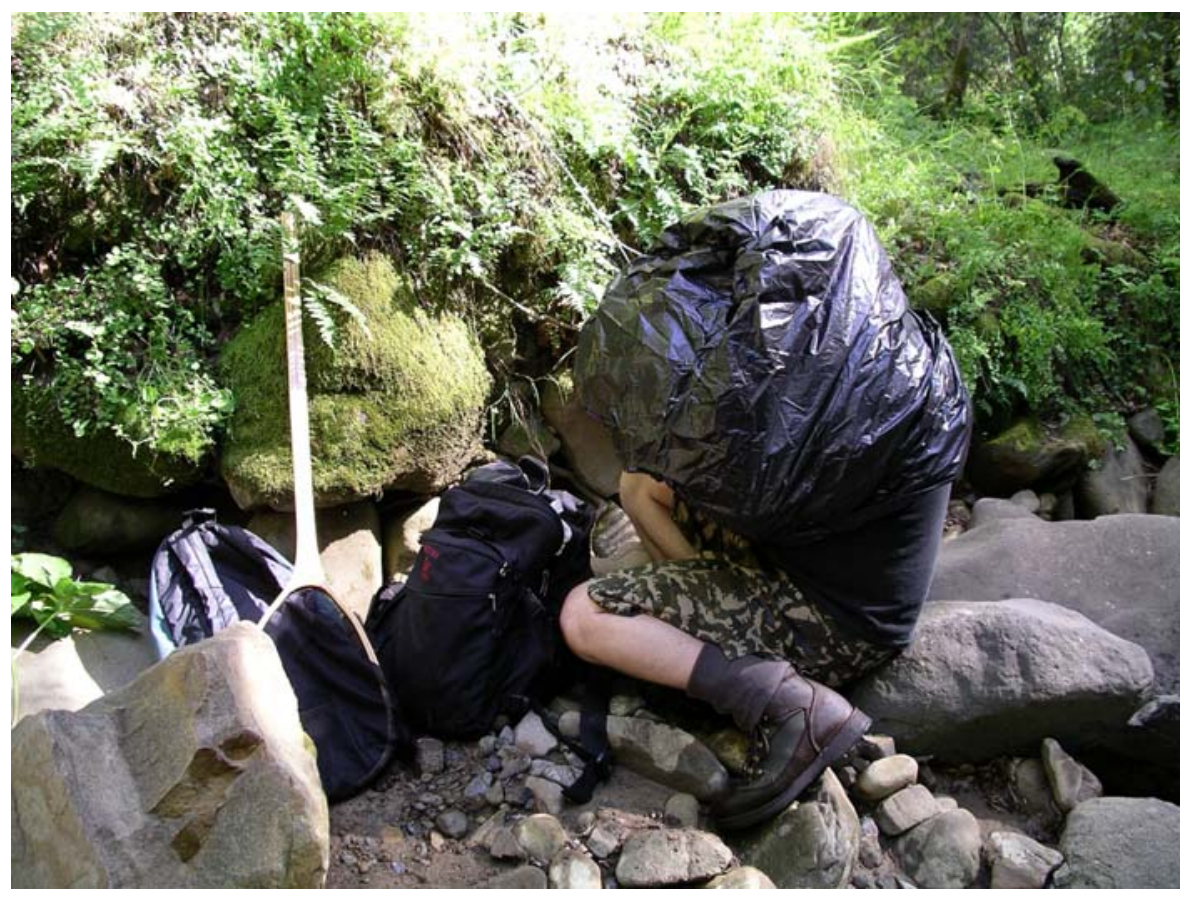

Рното 18.- Using a trash bag and an ultraviolet light lamp to read the elastomer alpha numeric tag on a recaptured frog. 


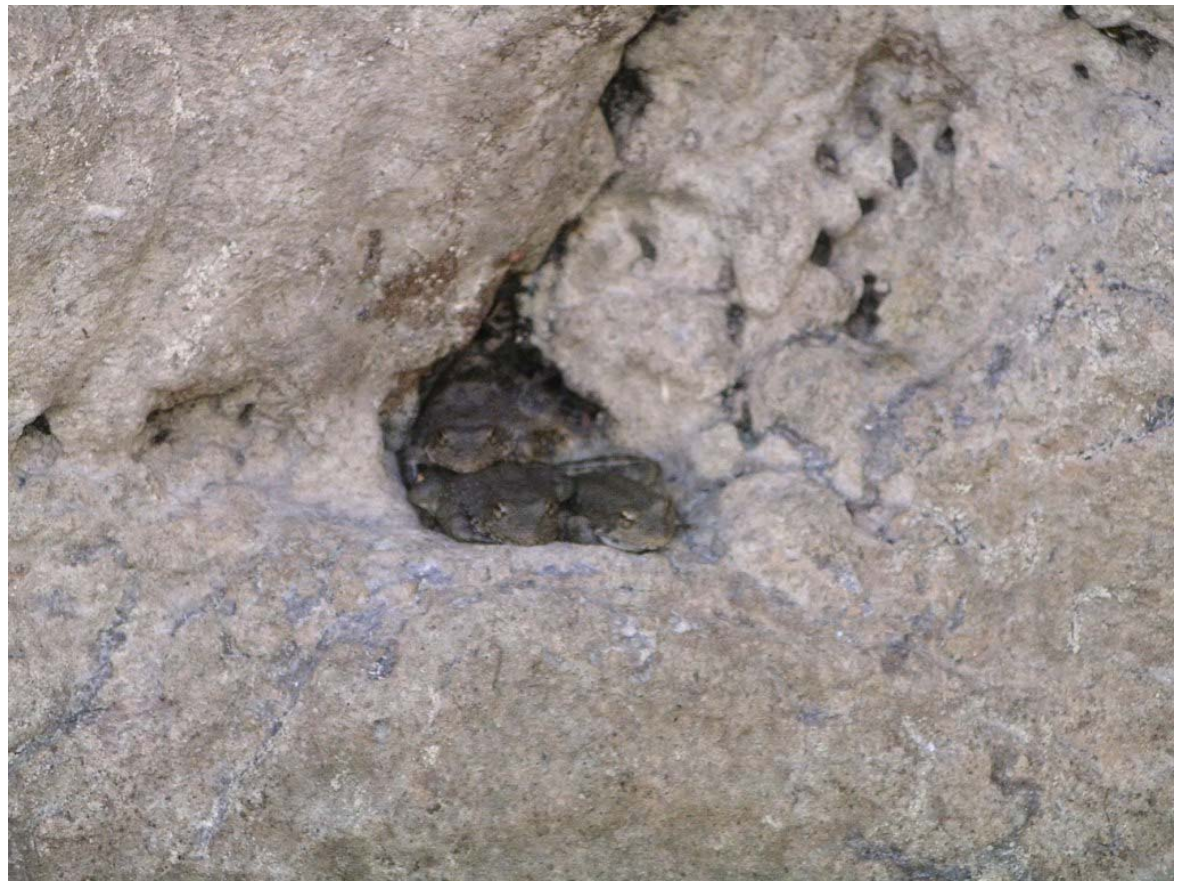

Pното 19.- A late summer aggregation of juvenile frogs during extremely high temperatures.

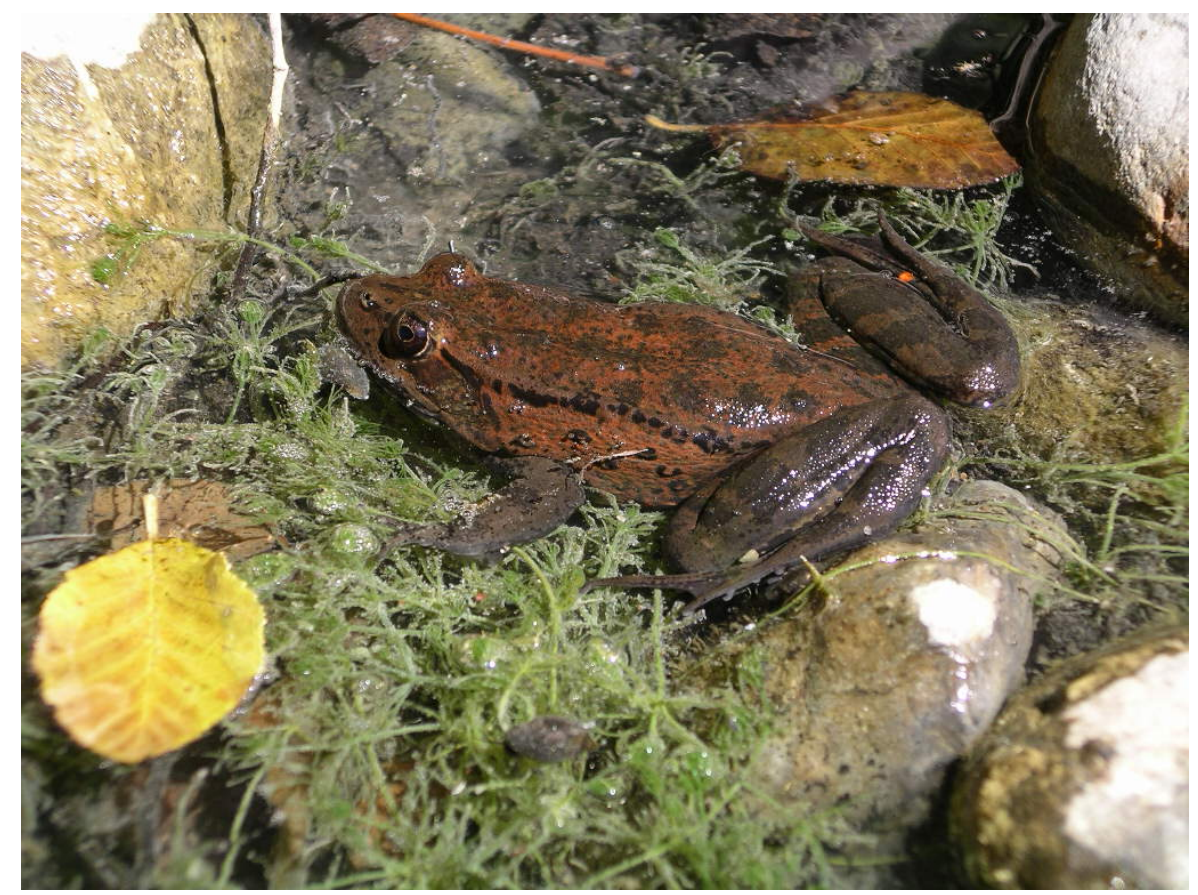

Рното 20.- A large female California red-legged frog that occupied the same habitat as foothill yellow-legged frogs. 


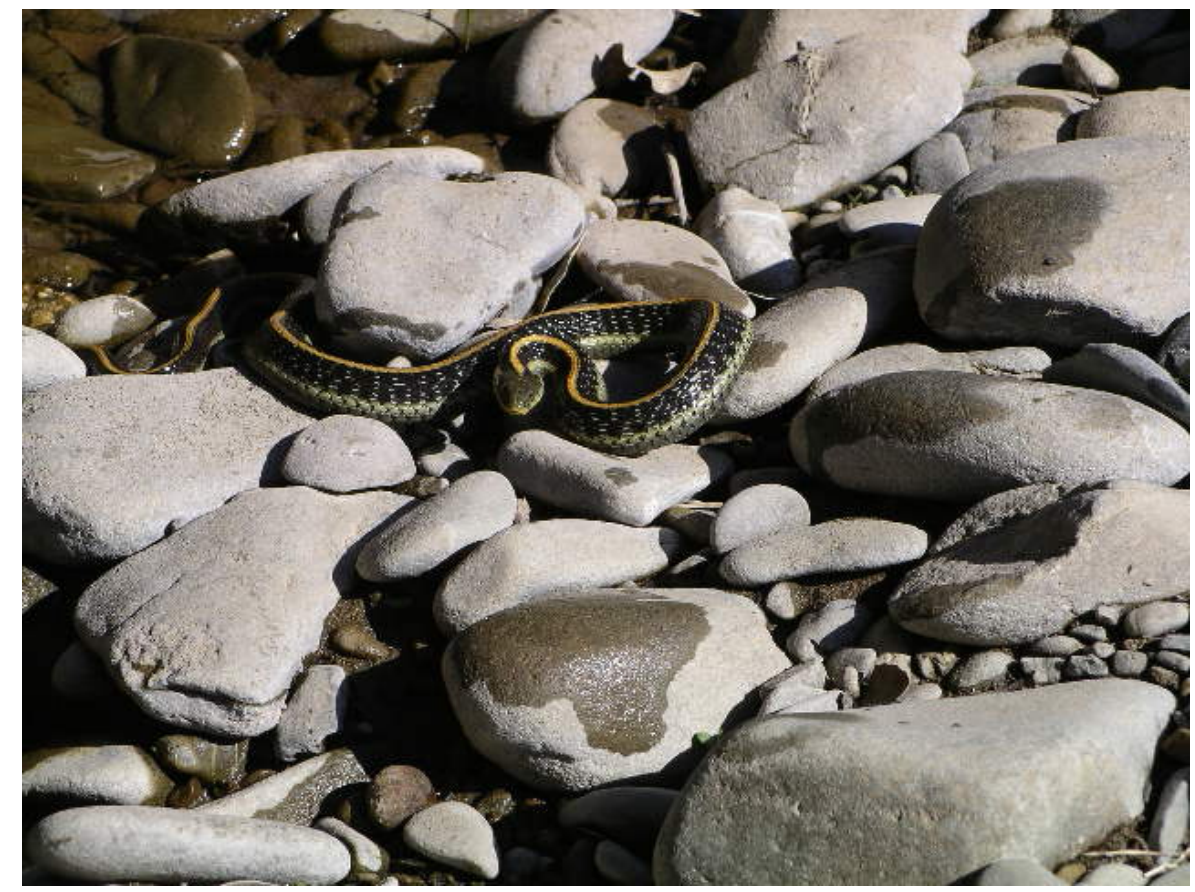

Pното 21.- The Santa Cruz aquatic garter snake was the most common predator within the study area.

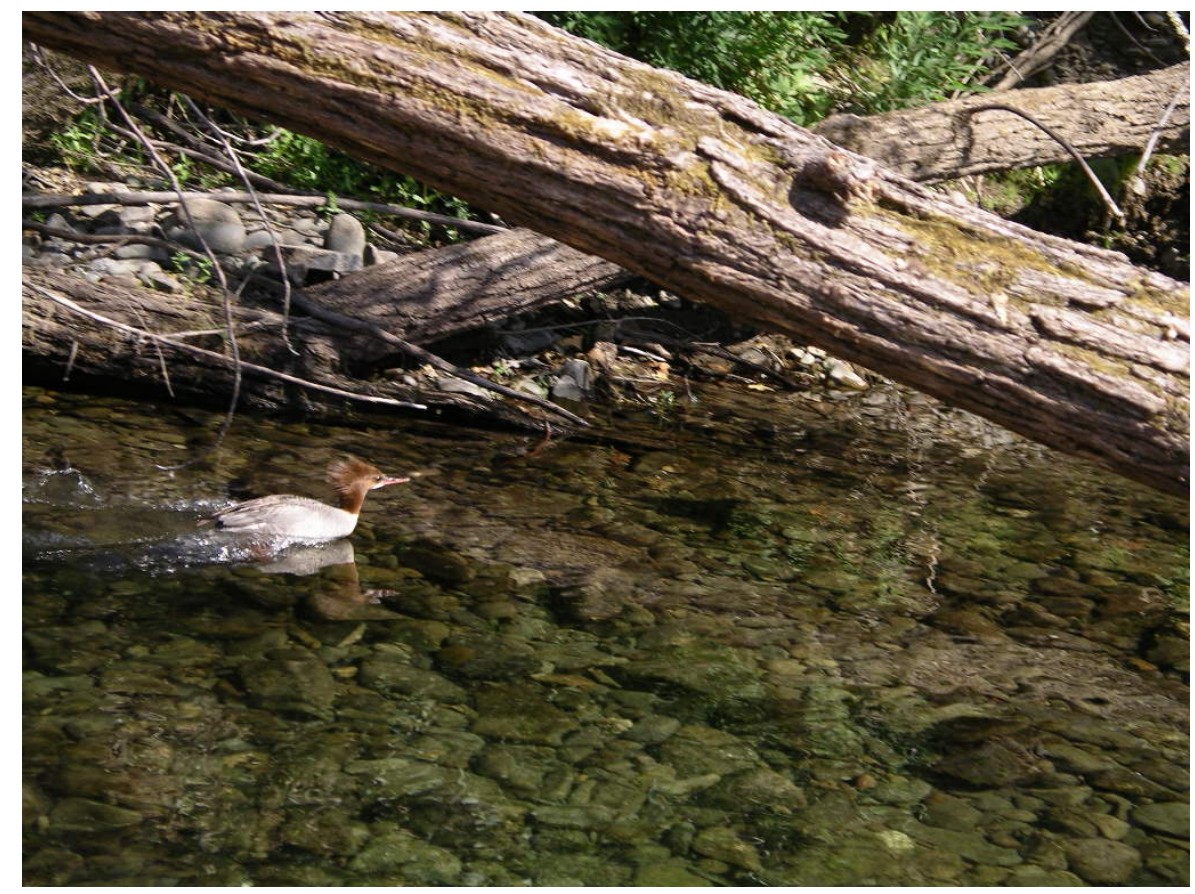

Pното 22.- The common merganser was an efficient predator on amphibian larvae. 


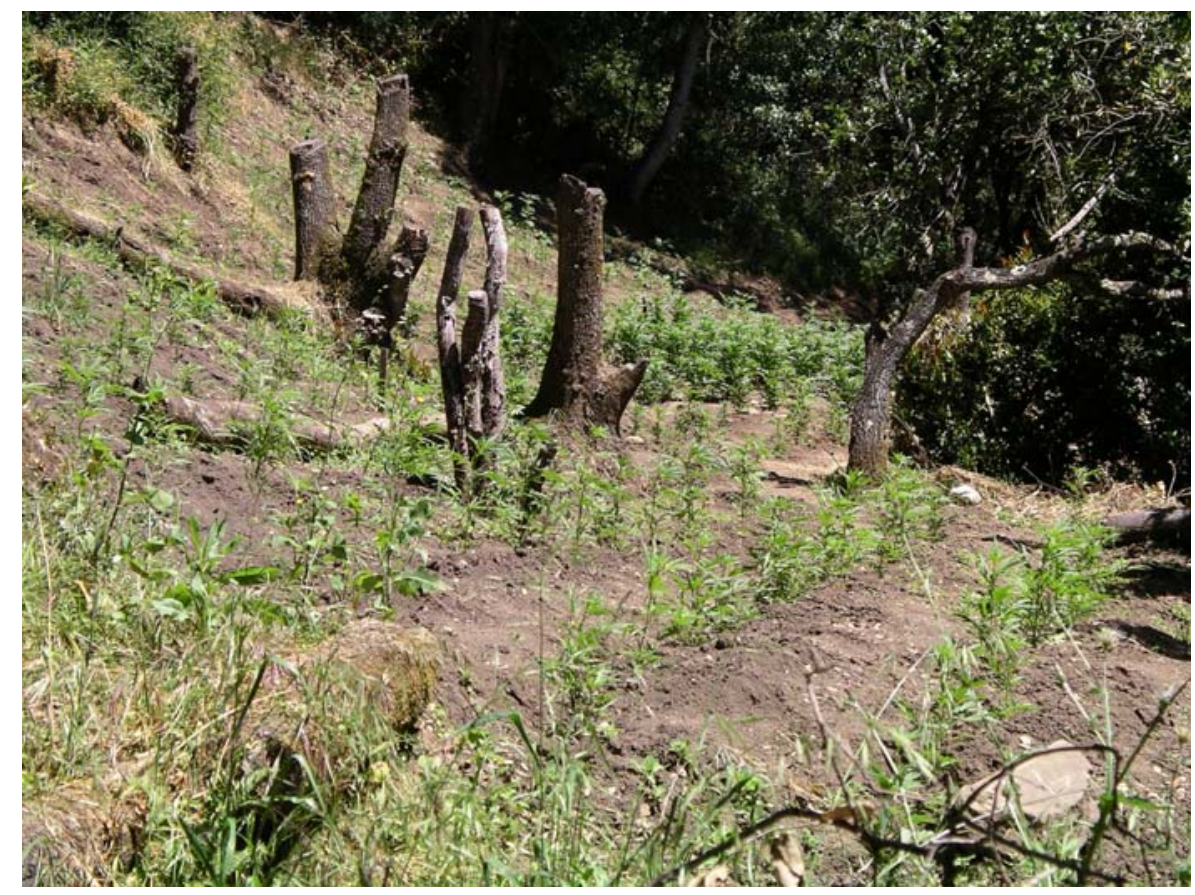

Pното 23.- Marijuana plants planted on terraces next to the tributary below Sheep Ridge. Note the terraced slopes, cut trees and cleared ground.

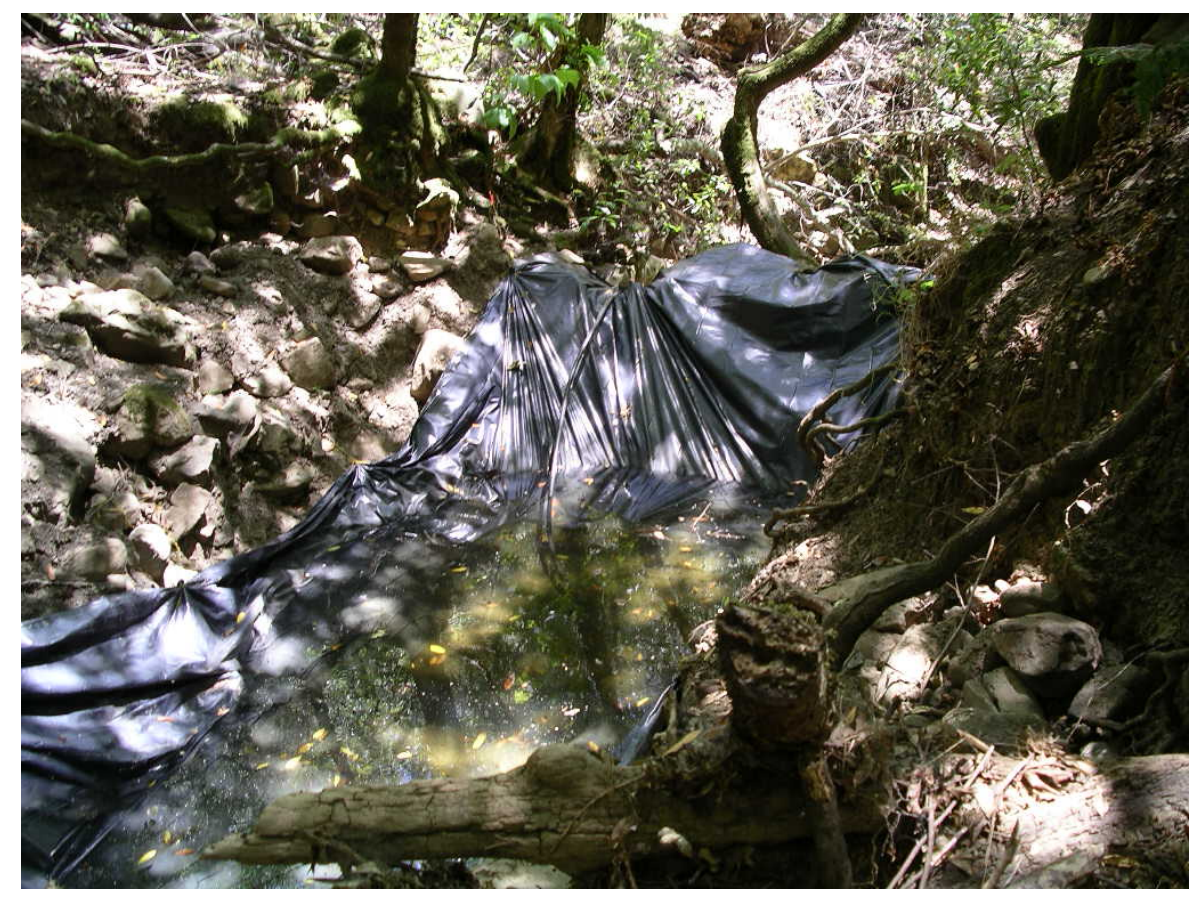

Рното 24.-Diversion dam that was constructed in a small perennial plunge pool on the tributary below Sheep Ridge. Irrigation lines brought water to the gardens downstream. 